\title{
A GLOBAL OVERVIEW OF FOREST PROTECTED AREAS ON THE WORLD HERITAGE LIST
}

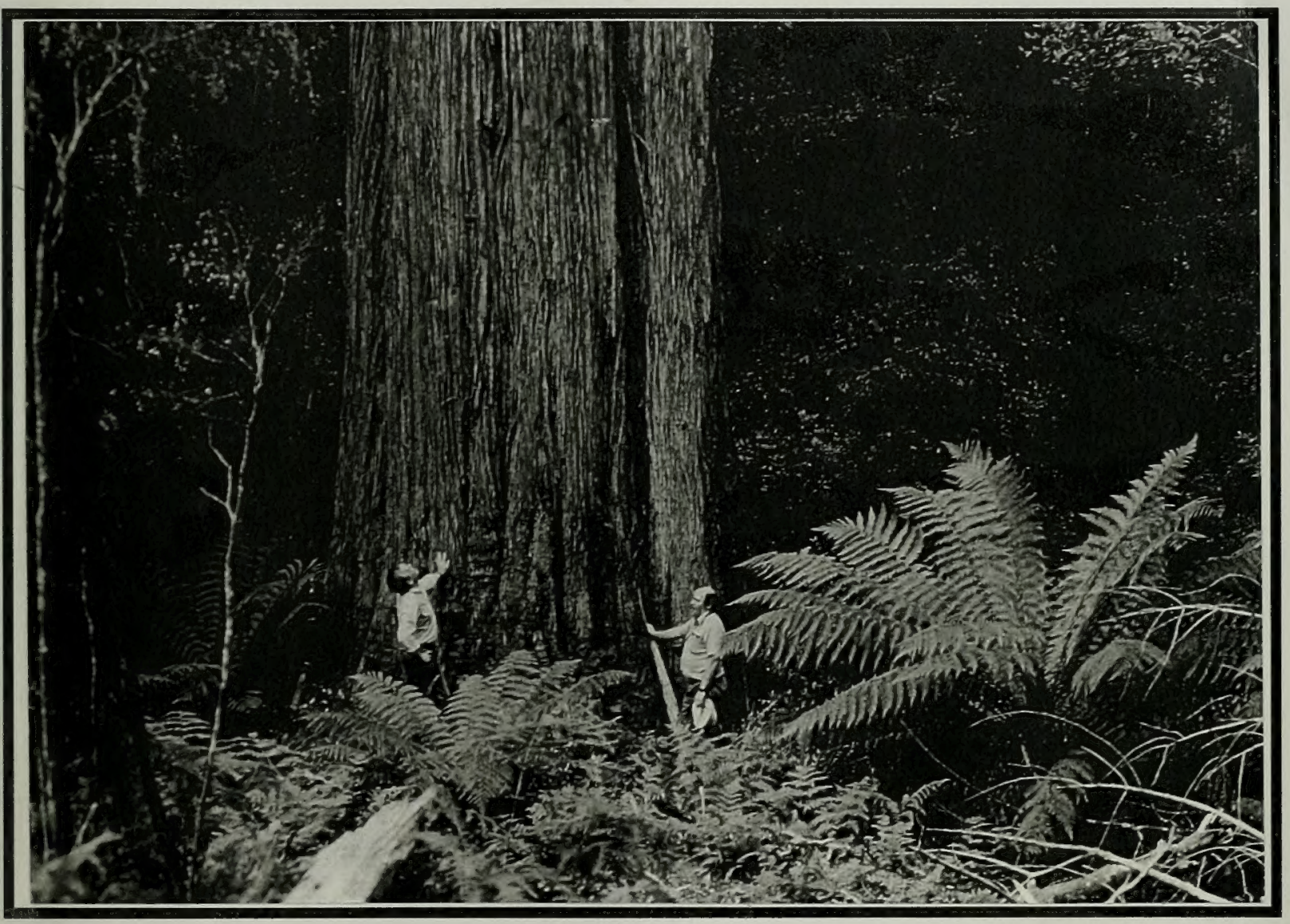

A Contribution to the Global Theme Study of World Heritage Natural Sites

Prepared by Jim Thorsell and Todd Sigaty

Natural Heritage Programme

IUCN

Gland, Switzerland

September 1997

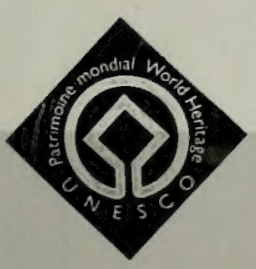


Digitized by the Internet Archive in 2010 with funding from UNEP-WCMC, Cambridge 


\title{
A GLOBAL OVERVIEW OF FOREST PROTECTED AREAS ON THE WORLD HERITAGE LIST
}

A Contribution to the Global Theme Study of World Heritage Natural Sites

\author{
Prepared by Jim Thorsell and Todd Sigaty \\ Natural Heritage Programme \\ IUCN \\ Gland, Switzerland \\ September 1997
}

Working Paper 1: Earth's Geological History - A Contextual Framework

Assessment of World Heritage Fossil Site Nominations

Working Paper 2: A Global Overview of Wetland and Marine Protected Areas on the World Heritage List

Working Paper 3: A Global Overview of Forest Protected Areas on the World Heritage List

Further volumes (in preparation) on biodiversity, mountains, deserts and grasslands, and geological features. 


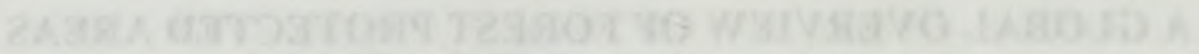

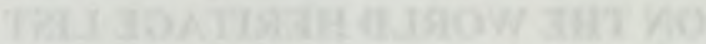

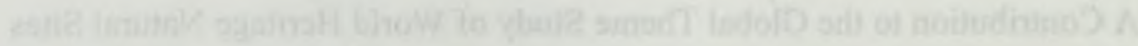

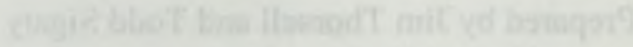

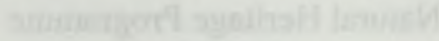

(15)ill

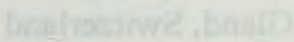

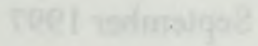

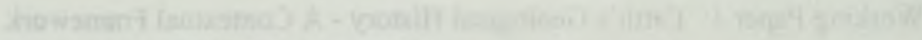

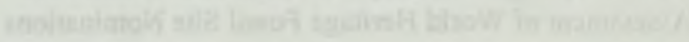

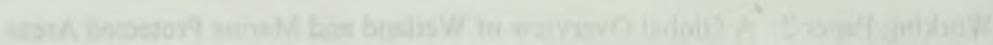

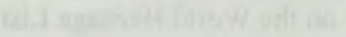

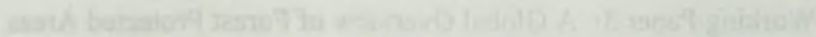

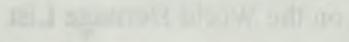

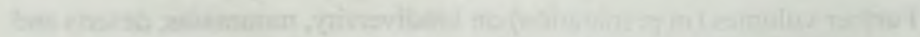

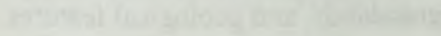




\section{TABLE OF CONTENTS}

PAGE

\section{Executive Summary $(\mathrm{e} / \mathrm{f})$}

II. Introduction

III. Tables \& Figures

Table 1. Forest protected areas on the World Heritage List

Table 2. Tropical moist forest protected areas on the World Heritage List 15

Table 3. Tropical dry forest protected areas on the World Heritage List 16

Table 4. Sub-tropical forest protected areas on the World Heritage List 16

Table 5. Temperate forest protected areas on the World Heritage List 17

Table 6. Boreal forest protected areas on the World Heritage List 17

Table 7. Forest protected areas inscribed on the List of World Heritage in Danger 18

Table 8. Forest protected areas which may merit consideration for World Heritage nomination 19

Figure 1. Distribution by realm forest protected areas on the World Heritage List 22

Figure 2. Total size of World Heritage sites with forest protected areas by biogeographic realm 22

Figure 3. Distribution by size World Heritage sites with forest protected areas 23

Figure 4. Number of tropical forest protected areas on the World Heritage List and total size of sites by biogeographic realm

IV. Maps

1. Forest protected areas in the Nearctic Realm on the World Heritage List 27

2. Forest protected areas in the Palearctic Realm West on the World Heritage List 29

3. Forest protected areas in the Palearctic Realm East on the World Heritage List 31

4. Forest protected areas in the Afrotropical Realm on the World Heritage List 33

5. Forest protected areas in the Indomalayan Realm on the World Heritage List 35

6. Forest protected areas in the Australian, Oceanian and Antarctic Realms on
the World Heritage List

7. Forest protected areas in the Neotropical Realm on the World Heritage List 39

\section{Detailed inventory of site}

1. Site inventory (annex) description

2. Forest protected areas inscribed on the World Heritage List 43

3. World Heritage Operational Guidelines, $\# 43-45$ 

Th-

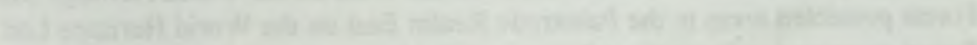

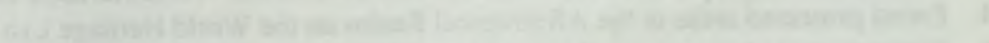

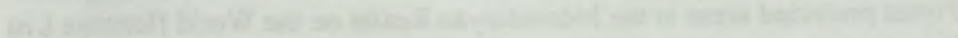
and (4)

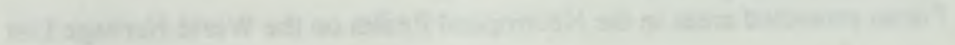




\section{EXECUTIVE SUMMARY}

This working paper provides a global overview of the current coverage of forest protected areas on the World Heritage List and suggests potential forest areas which may merit future nomination to this prestigious List. Despite the essential role that forests play in climate control. flora and fauna habitat, and in the lives of the human population, they continue to be one of the most threatened biomes. Recent estimates indicate that nearly $50 \%$ of the world's original forest cover has been lost and over 4,000 tree species have been listed by IUCN as globally threatened.

In 1996, IUCN's Natural Heritage Program began a project to prepare a global strategy for natural World Heritage sites. As part of this project, this working paper on forests is the third in a series of global overviews of the various biomes of the world (e.g. wetlands, forests, mountains, deserts, grasslands, etc.). These theme studies involve close co-operation with the World Conservation Monitoring Centre (WCMC) and have benefitted from the support of Australia's Department of Environment.

This working paper identifies the 61 forest protected areas currently on the World Heritage List, representing 39 countries and over 50 million ha of protected area. It further locates 25 potential forest protected areas from various global regions which may merit future World Heritage nomination. The 61 sites are categorised by forest type (tropical moist, tropical dry, sub-tropical, temperate and boreal) and biogeographical realm and numbered to provide the reader easy reference to the tables, figures and maps.

The annex includes a summary description of all 61 forested protected sites on the World Heritage List cross referenced with their relations with other international programs and conventions (e.g. Biosphere Reserves and WWF Global 200 Ecoregions). Although Ramsar is not mentioned, 37 of the 61 sites in this overview were categorised in working paper 2 as World Heritage sites with wetland and marine values. A gap analysis of the sites listed in this overview indicates that a limited number of forest protected areas presently exist on the World Heritage List within Amazonia (Neotropical Realm), portions of the Indomalayan Realm, the boreal regions of the Palearctic realm, and no sites exist in the Oceanian Realm (Papua New Guinea and the North and South Pacific).

It is hoped that this overview will assist IUCN in making comparative evaluations and provide the World Heritage Committee with a firmer scientific basis for making decisions on new World Heritage nominations. It will also provide State Parties with a global perspective which is useful when identifying potential World Heritage properties in their territories. 
Than

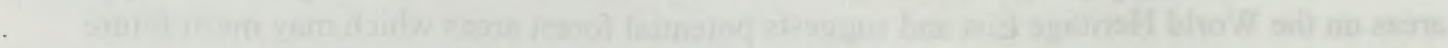

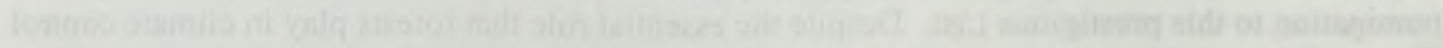

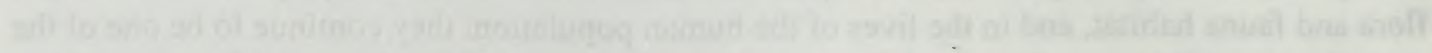

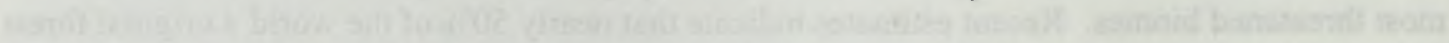

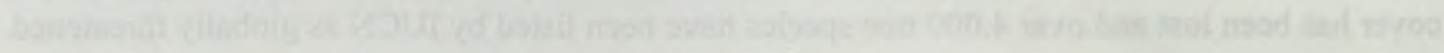

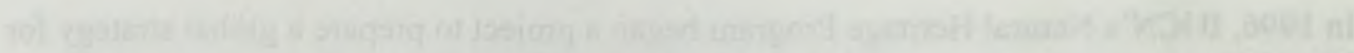

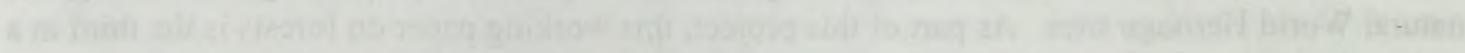

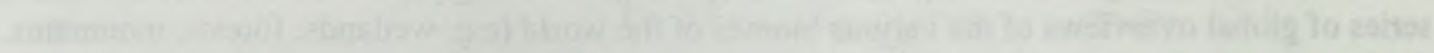

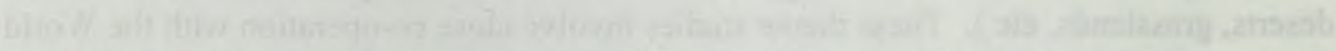

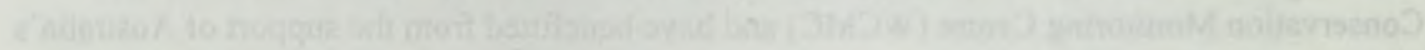

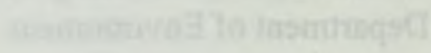

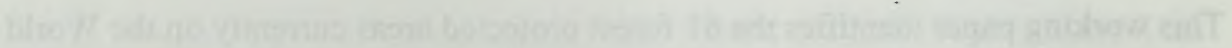

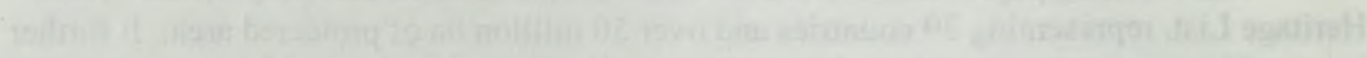

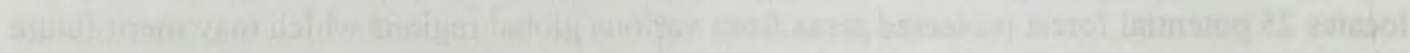

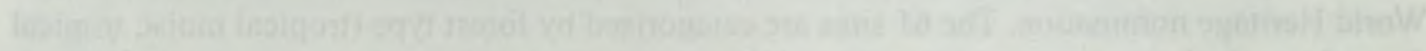

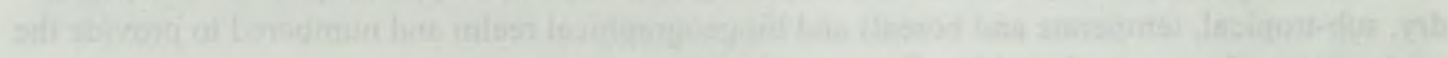

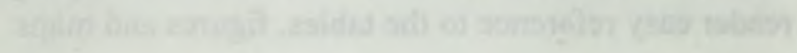

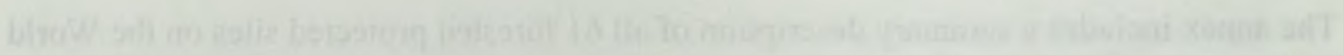

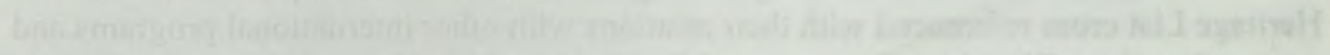

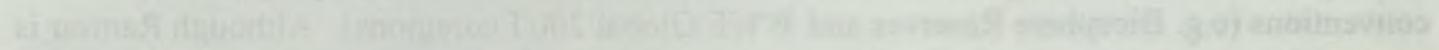

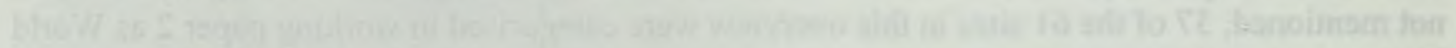

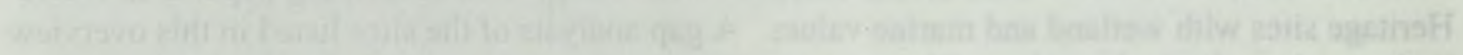

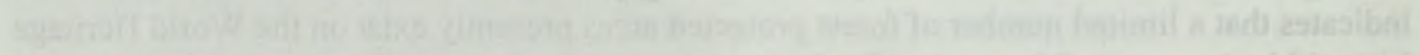

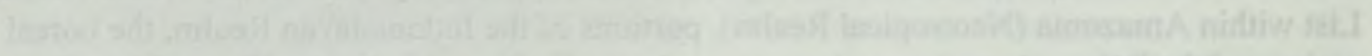

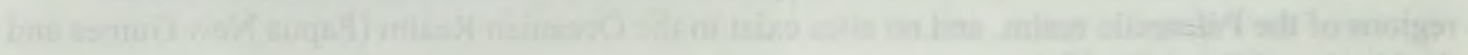

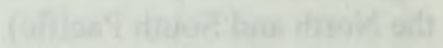

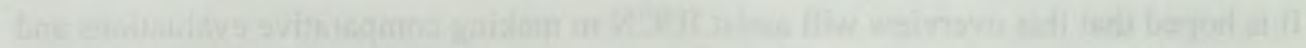

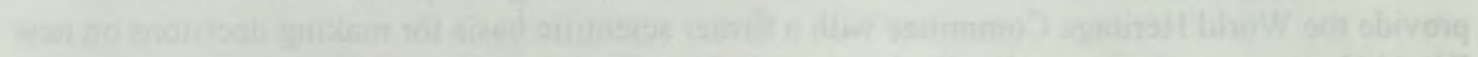

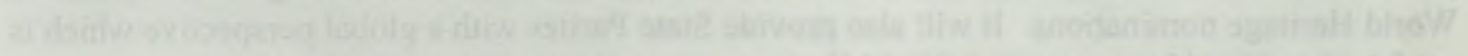

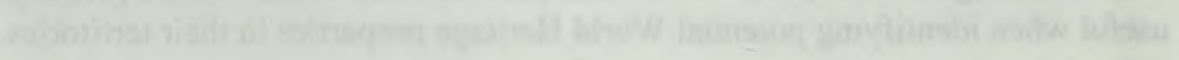




\section{RESUME}

Ce document de travail présente un bilan au niveau planétaire des forêts protégées qui se trouvent sur la Liste du patrimoine mondial. Des forêts qui pourraient mériter d'être inscrites sur cette Liste prestigieuse y sont proposées.

Les forêts jouent un rôle essentiel dans la régulation du climat, servent d'habitat pour la flore et la faune et influencent considérablement la vie des populations humaines. Elles demeurent cependant l'un des biomes les plus menacés. Près de $50 \%$ de leur superficie mondiale originelle a été perdue et plus de 4000 espèces d'arbres ont été inscrites par l'UICN sur la Liste des espèces menacées.

En 1996, le Programme pour le patrimoine naturel de I'UICN a entrepris un projet dont le but est d'élaborer une stratégie mondiale pour les sites naturels du patrimoine mondial. Produit dans le cadre de ce projet, ce tome sur les forêts est le troisième d'une série de bilans mondiaux relatifs aux biomes de la planète (par exemple, zones humides, forêts, montagnes, prairies). Ces études thématiques sont réalisées en étroite coopération avec le "World Conservation Monitoring Centre" (WCMC) et à l'aide du soutien généreux du Département de l'environnement d'Australie.

Actuellement, 61 forêts se trouvent sur la Liste du patrimoine mondial (y compris 30 en région tropicale), représentant 39 pays et plus de 50 millions d'hectares d'aires protégées. Ces sites sont regroupés en catégories selon le type de forêts qu'ils comprennent (forêt tropicale humide, tropicale aride, subtropicale, tempérée ou boréale) et leur appartenance biogéographique, afin de permettre au lecteur de se référer aisément aux tables et plans. Une brève description des 61 forêts du patrimoine mondial se trouve en annexe et met en évidence leur relation avec d'autres programmes et conventions (par exemple, Réserves mondiales de la Biosphère, Ecorégions mondiales 200 de WWF).

L'analyse démontre que peu de forêts appartenant au patrimoine mondial se situent en Amazonie, dans le Pacifique Sud, certaines régions du Sud-Est asiatique, et les régions de forêts boréales.

Cet inventaire devrait assiter l'UICN à effectuer des évaluations comparatives et devrait fournir au Comité du patrimoine mondial une base scientifique plus solide pour ses prises de décisions relatives aux nominations à venir pour le patrimoine mondial. Les Etats Parties auront aussi à leur disposition une perspective mondiale qui les assistera à identifier des sites potentiels pour le patrimoine mondial au sein de leur territoire. 


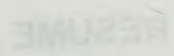

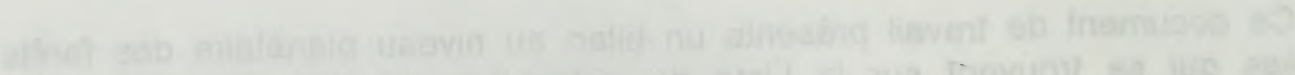

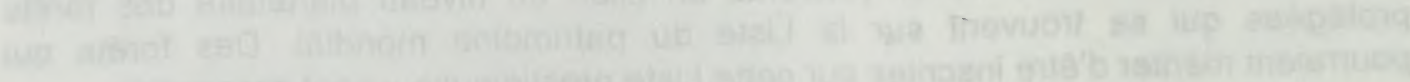

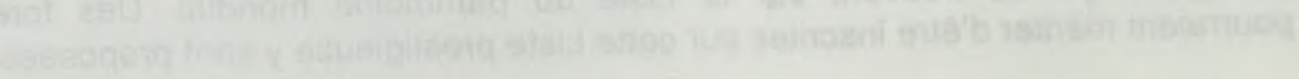

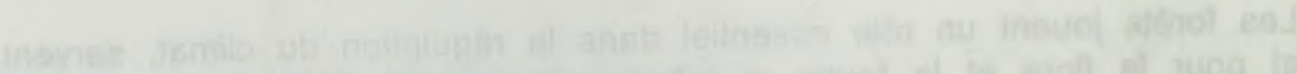

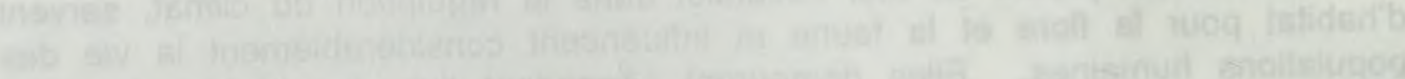

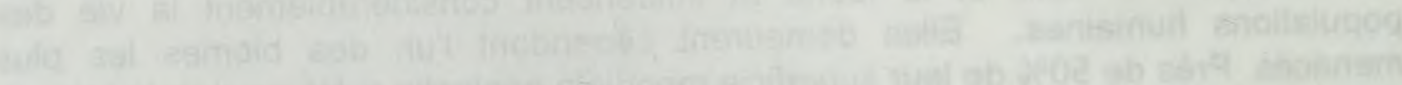

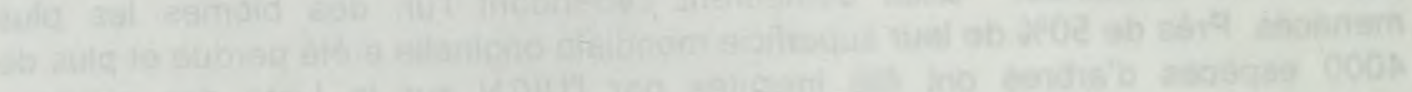

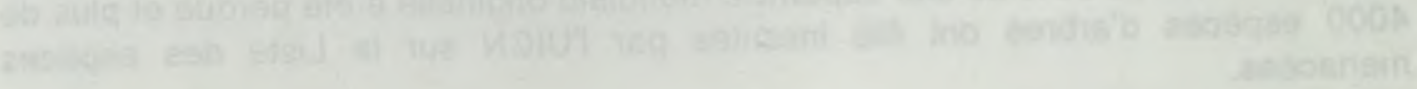

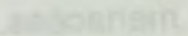

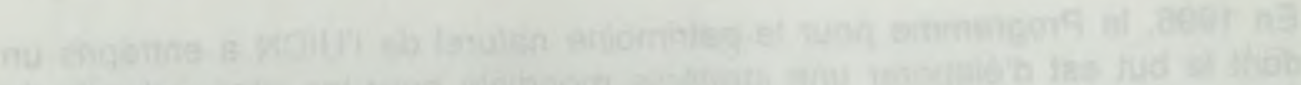

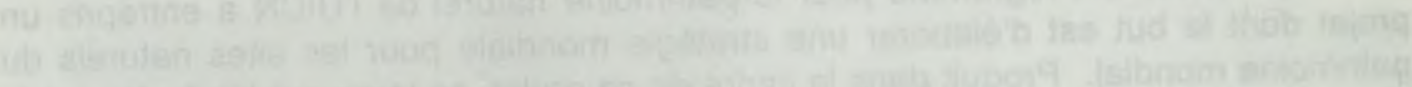

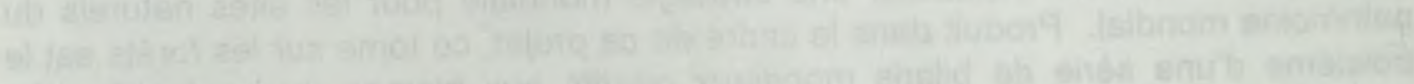

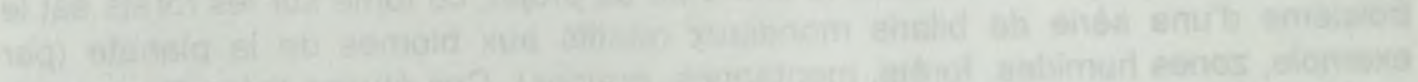
Th:

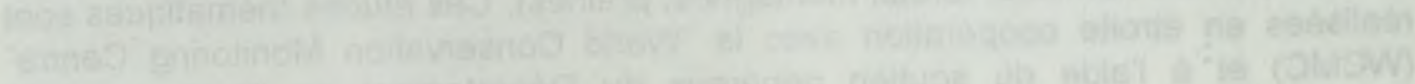

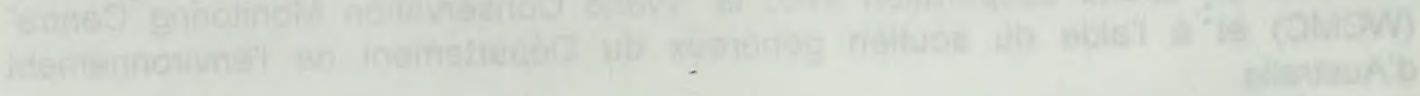

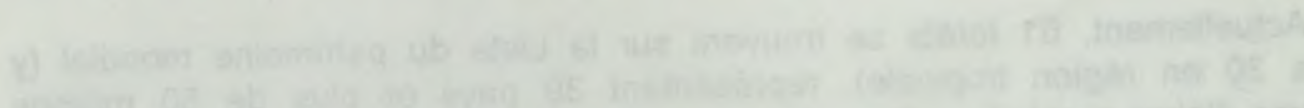

1.2.

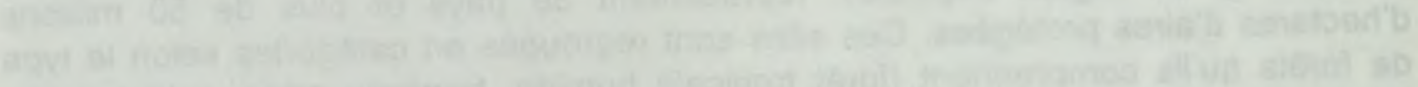

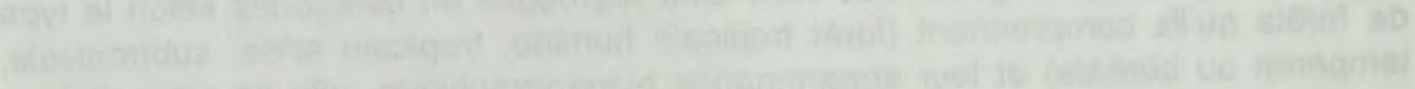

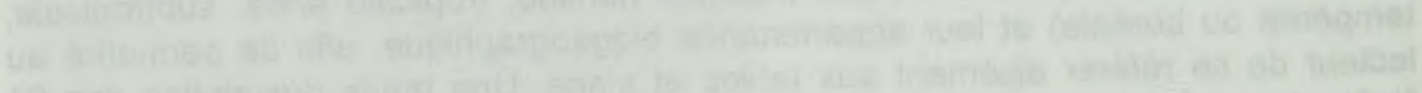

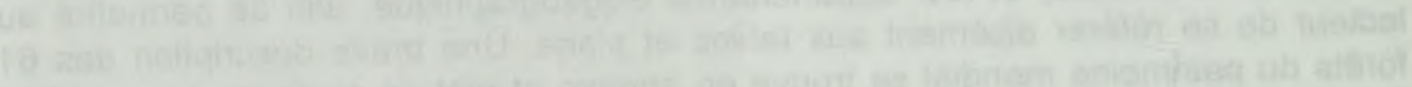
Wath the

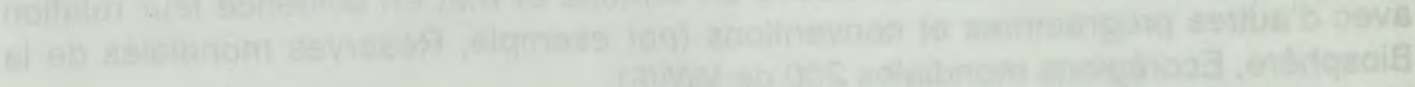

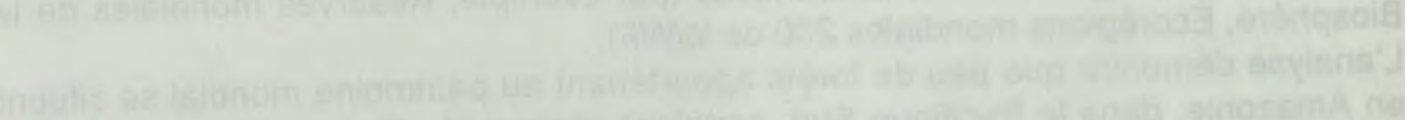

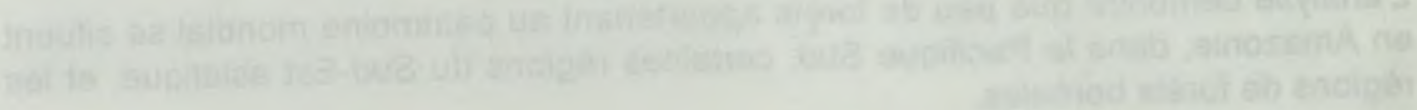

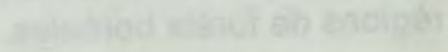

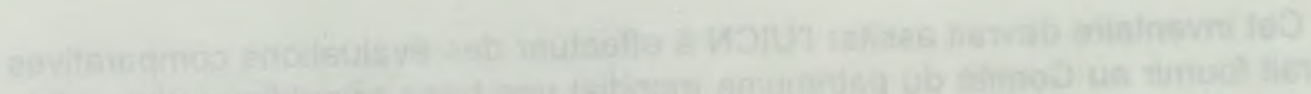

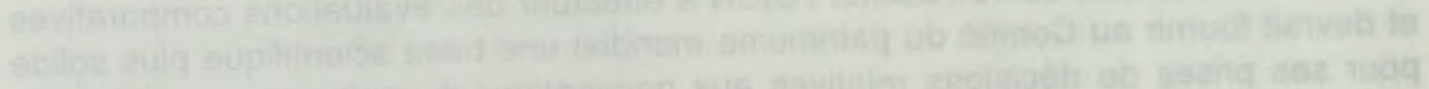

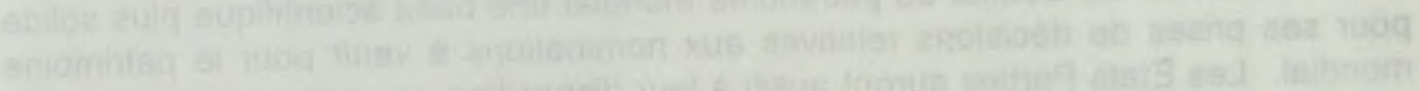

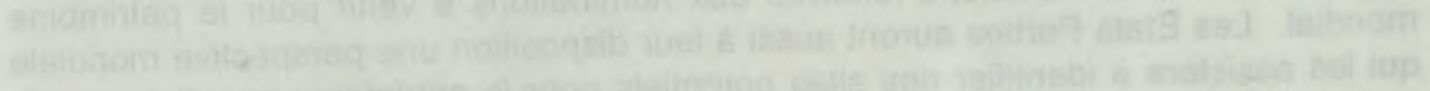

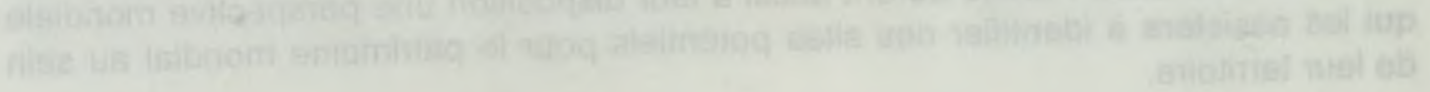




\title{
A GLOBAL OVERVIEW OF FOREST PROTECTED AREAS INSCRIBED ON THE WORLD HERITAGE LIST
}

\author{
"Of vast circumference and gloom profound \\ This solitary Tree! - a living thing \\ Produced too slowly ever to decay; \\ of form and aspect too magnificent \\ to be destroyed."
}

From "Yew Trees," William Wordsworth, 1770-1850.

\section{Introduction}

In 1996, IUCN's Natural Heritage Program initiated a project to prepare a global strategy for natural World Heritage sites. It was foreseen to prepare global overviews on World Heritage site coverage in the various biomes of the world (e.g. forests, wetlands, mountains, grasslands, etc.) and an overview of biodiversity values of World Heritage sites. The project would involve close co-operation with the World Conservation Monitoring Centre (WCMC) where the world's major biodiversity and protected area database is located. Support for the conduct of these theme studies was generously provided by Australia's Department of Environment.

The first in this series of working papers was the global theme study on "Earth's Geological History - A Contextual Framework for Assessments of World Heritage Fossil Site nominations." This report was prepared over the course of a year by Professor Rod Wells of Flinders University and was made available to the World Heritage Committee in December, 1996. It provides a temporal view of where fossil records best display the record of life on earth (natural heritage criteria i).

The second in the series was an overview of World Heritage natural sites with wetland and marine values prepared by IUCN's Natural Heritage program in September, 1997. It reviews 77 World Heritage sites with significant wetland and marine values and describes over 40 wetland and marine areas which may meit consideration for future nomination on the World Heritage List. Many of these potential sites are located in areas with minimal World Heritage protection at the current time.

This working paper is the third in the series and focuses on forest protected areas on the World Heritage List. It was first initiated at the "International Conference on World Heritage Forests," held in Queensland in September, 1996. with a background paper by Jim Thorsell and Jim Paine. It will also serve as useful background to the "World Heritage Convention as an International Instrument for Biodiversity Conservation in Tropical Rainforests", to be held in Brestagi, Northern Sumatra, Indonesia in May, 1998.

The purpose of this working paper is twofold: first, to inventory forest protected areas on the World Heritage List which provides an overview of the current "coverage;" and second, to locate potential forest protected areas from various global regions for future inscription on the World Heritage List (gap areas). 
This overview identifies 61 forest protected areas on the World Heritage List and describes 25 forest protected areas which may merit consideration for future nomination. Thirty-seven of the 61 forest protected areas on the World Heritage List were included as World Heritage Sites with wetland and marine values (working paper \#2), 15 categorised as major wetland sites and 22 as secondary. This overview will assist IUCN in making comparative evaluations and provide the World Heritage Committee with a firmer scientific basis for making decisions. It will also be of interest to State Parties as it will provide them with a global perspective which is useful when identifying potential World Heritage properties in their territories.

\section{What are forests?}

There are probably as many definitions of "forests" as there are sources. Although we all know a tree when we see it, defining a forest by type and amount of forest cover are difficult and oft-debated tasks. Moreover, a forest is a complex system of numerous species and ecological processes. Despite the biodiversity within forest ecosystems, most statistics have focused primarily on the amount of forest cover. The Food and Agricultural Organisation of the United Nations (FAO), in previous reports have defined forests as "ecological systems with a minimum of $10 \%$ crown cover of trees and/or bamboos, generally associated with wild flora and fauna and natural soil conditions and not subject to agricultural practices." In the case of developed countries, a forest is often defined by a minimum of $20 \%$ forest cover. The density and quality of species are also important characteristics to consider in defining forests, a topic which will be addressed in a future working paper on biodiversity values of World Heritage sites. For the purposes of this working paper, forest protected areas on the World Heritage List were included if the nominations of the respective State Parties or WCMC forest data revealed a substantial amount (defined in section III) of forest cover within the site.

According to recent estimates, over 35 million sq. $\mathrm{km}$ of forest cover remain in the world. Tropical forests comprise nearly $50 \%$ (17 million sq. $\mathrm{km}$ ) of the remaining global forest, but have the highest rate of deforestation (4-8\%) of the forest biomes. Central and South America contain $60 \%$ of the world's rainforest with the remaining portion being divided evenly between West Africa, Southeast Asia and the South Pacific. Tropical forests are located within an equatorial belt between 4 degrees north and south of the equator in areas with a constant temperature of 18-30 degrees Celsius and an evenly distributed rainfall of over $2,000 \mathrm{~m}$ per year. This overview identifies tropical moist and tropical dry forest protected areas, which provide habitat for nearly $80 \%$ of the world's species.

Temperate forest comprises 8 million sq. $\mathrm{km}$ of forest cover and occurs within a belt between 32 and 60 degrees latitude. Temperate forests vary in composition and conditions, but usually contain open forests with beech, maple, oak and other deciduous trees. Temperate rainforest contains evergreen moist and deciduous trees and exists in a few coastal regions of the temperate zone. Only pockets of virgin growth temperate forests remain (2 to $3 \%$ ) in Central Europe, Asia and North America, making them one of the most threatened forest biomes.

The remaining 10 million sq. $\mathrm{km}$ of global forest cover are the coniferous forests in the boreal zone which occur in the northern latitudes across Canada, 
Alaska, Scandinavia and Siberia above the temperate broad leaf zone. The boreal forest is not a uniform expanse of trees, but merges with tundra vegetation. Each of these forest biomes are important resources for local populations and as habitat for numerous flora and fauna species.

\section{Criteria}

This working paper attempts to identify the forest protected areas on the current World Heritage List. As of 1996, 123 natural and mixed (natural/cultural) sites comprise the World Heritage List representing 62 countries. Many of these sites contain some forest, but only sites containing forest protected areas with significant forest cover were selected for this overview.

The indication of whether or not the amount of forest cover within each site was significant was based primarily on two criteria. The first, and most important source, was information regarding the type and amount of forest provided by the State Party in the nomination for World Heritage designation. The second source of information used to make this decision was derived from the WCMC database for each World Heritage site and forest database files. In the database files, forest cover is calculated on the basis of whether a $8 \mathrm{~km} \times 8 \mathrm{~km}$ grid cell is more than $50 \%$ forested. In order to make mangrove forests, mixed mountain forest areas, and island system forest areas visible on a global scale, any grid cell containing these categories was classified as being entirely forested. A site was included in this overview if either or both of these sources revealed $20 \%$ or more forest cover within the site or if the amount of forest cover was a primary reason why the site was nominated and inscribed on the World Heritage List. This data can be unreliable since World Heritage sites represent small areas when overlayed with global forest data plots, but improved forest data for each World Heritage site is being completed by WCMC and will be included in future revisions of this working paper.

Based on this selection process, this working paper lists and describes 61 of the 123 World Heritage sites as containing significant forest protected areas. Therefore, for each of the 61 sites, either the information provided by the State Party in the site nomination stated that the forest component was a significant characteristic of the site or the forest data identified forest cover greater than $20 \%$ of the total size of the World Heritage site. When necessary, information on forest cover and forest type was also obtained from published articles on particular sites, as well as from observations and reports made from World Heritage site visits.

In order to present a harmonised overview, a broad; pragmatic and global forest classification system has been used for this working paper. Each national data set or map was translated into five forest classes: tropical moist; tropical dry; sub-tropic; temperate; and boreal. Moist forests in the tropics, which are synonymous with rain or humid forests, include lowland and montane rainforest, and seasonal monsoon forests. Dry forests generally seasonally deciduous, but may also include pine forests, particularly in Central America and the Caribbean. If a site contained a portion of two forest types or a type not listed, it was listed in the category with the largest percentage (Tables 2-6), however, a complete description of all forest types in each site has been included in the Annex 1. 
Most World Heritage sites represent a large land area with multiple natural values. For this reason, many sites contain some forest area, but were not included in this inventory since the data revealed less than $20 \%$ forest cover within the site and/or the forest area was not a significant characteristic when considering the World Heritage site in its entirety. Examples of World Heritage sites not included in this overview for such reasons include: Tatsheshini-Alsek/Kluane National ParkMrangell-St. Elias National Park and Reserve/Glacier Bay National Park (white boreal forest); Mammoth Caves National Park ( 84 tree species and one of last remaining examples of eastern North America ancient forest); Wulingyuan Scenic and Historic Interest Area (maple, pine, oak and Chinese plum yew); The Lapponian Area (over 100,000ha of pristine pine and fir forest); Volcanoes of Kamchatka (boreal forest); Komodo National Park (tropical monsoon and quasi cloud forests); Grand Canyon (over 100,000ha of temperate forest); and Huascaran National Park (highest altitude tropical rain forest in the world). In fact, almost all natural World Heritage sites contain some forest component, however, only those considered highly significant have been included in this document.

\section{Format of the Overview}

The Overview is divided into two sections:

\section{Forest protected areas on the World Heritage List (61 sites)}

These 61 sites were categorised as forested protected areas on the World Heritage List based on the criteria stated above in section III. Although many sites were inscribed on the World Heritage List for meeting several criteria, the forest value for these sites was listed in the site nomination by the respective State Party as a major reason for inscription on the World Heritage List.

\section{Analysis of forest protected areas on the World Heritage List - summary tables, figures and maps}

To assist in analysis, the following tables and figures are attached:

Table 1 Forest protected areas on the World Heritage List

Table 2 Tropical moist forest protected areas on the World Heritage List

Table 3 Tropical dry forest protected areas on the World Heritage List

Table 4 Sub-tropical forest protected areas on the World Heritage List

Table 5 Temperate forest protected areas on the World Heritage List

Table 6 Boreal forest protected areas on the World Heritage List

Table 7 Forest protected areas inscribed on the List of World Heritage in Danger

Table 8 Forest regions that contain protected areas which may merit consideration for World Heritage nomination

Figure 1 Distribution by realm of forest protected areas on World Heritage List

Figure 2 Total size of World Heritage sites with forest protected areas by realm

Figure 3 Distribution by size of World Heritage sites with forest protected areas

Figure 4 Number of tropical forest protected areas on the World Heritage List and total size of sites by biogeographic realm 
Attached are also seven maps which show the location of forest protected areas on the World Heritage List. On a global scale all but the very largest World Heritage sites are too small to be represented clearly. For this reason, seven maps of the forest protected areas on the World Heritage List have been prepared, each representing biogeographic realms: Nearctic; Palearctic (two maps); Afrotropical; Indomalayan; Neotropical; and (Oceanian Australian; and Antarctic mapped together). These maps show the location of forested protected areas on the World Heritage List within each realm. Each map categorises the forest cover into tropical moist, tropical dry, sub-tropic, temperate, and boreal. World Heritage sites are listed according to their corresponding number in Annex 1 and Tables 2-6. Each site is listed by name in the map legend.

\section{Data Sources}

Decisions regarding which World Heritage sites to inclucie in the overview were primarily based on information extracted from the WCMC database. The database contains a record for each World Heritage site and includes discussion on the physical features, vegetation, flora and fauna, and conservation value of each site. WCMC drafts and updates the Data Sheets on the database based on materials received from the State Party and other sources. Reference was also made to Global Biodiversity: Status of the Earth's Living Resources (1992), a WCMC publication. Data for the amount of forest within each World Heritage site was compiled from the WCMC database and GIS files which attempt to present a comprehensive picture of the extent of the remaining global forest cover and its relation with World Heritage protection. The data are accurate to approximately $1: 1,000,000$ scale and are based on maps and digital files from national and international sources from the early 1980 s to early 1990 . Much of this data is difficult to to overlay with World Heritage sites, but has recently been updated in World Conservation Monitoring Centre. Iremonger, S., C. Ravilious and T. Quinton (eds.) (1997) A Global Overview of Forest Conservation. CD-ROM. WCMC and CIFOR, Cambridge, U.K. The original sources differed greatly in their accuracy, classification, and the definition of the term "forest". There were errors in tine amount of forest within certain World Heritage sites and comments regarding total forest coverare are invited to assist in a future update of this working paper. New data from WCMC will better define the amount of forest cover within each World Heritage site and will be printed in future revisions of this working paper.

In compiling this overview several IUCN publications were used, including Review of the Protected Areas System in the Indomalayan, Oceanian and Afrotropical Realms (1986); Conservation Atlas of-Tropical Forests - vols I, II, and III (1991); The World Heritage Convention, Twenty Years Later (1993); IUCN Red Book (1994); Paradise on Earth (1995), The World's Centres of Plant Diversity - vol. I, II, III (1995); as well as articles, conference proceedings and secondary sources. Other valuable resources were the UNESCO publication of current Biosphere Reserves; "Forests in a Changing World," by Jeff Sayer (1992); Nature's Last Refugees (1992) by Robert Burton; FAO's Tropical Forest Action Plan; Nature in Danger: Threatened Habitats and Species (1993) by Noel Simon and WCMC; and The Last Frontier Forests (1997) by the World Resources Institute; and various other articles and national forest website information. 


\section{Observations and Future Suggestions}

"Humans" have occupied and relied upon forest areas for thousands of years. This relationship continues today as humans become even more dependant on forests as an important resource economic, cultural, ecological and recreational resource and essential habitat for numerous threatened and endangered species of flora and fauna. Some of the most notable services and products provided by forests include: climate control, shelter, food, clothing, fuel, medicines, building materials, water quality, storm protection, and habitat for fauna.

Despite their importance, forests remain among the world's most threatened biomes. Nearly $50 \%$ of the earth's original forest have been lost, mainly in the past three decades. Morevover, only $20 \%$ of original forest cover remain in large tracts of undisturbed forest, of which $70 \%$ is located within Russia, Canada and Brazil. A mere $3 \%$ of these large undisturbed tracts are temperate forests. Equally as threatened are tropical moist forests, which have lost $50 \%$ forest cover over the last few decades to plantations, grazing or scrubland. Each year, some 10 to 50 million ha $(300,000$ ha per day) of virgin forest are lost. With over $50 \%$ of all terrestrial species inhabiting the world's forests, this loss of habitat is resulting in massive species extinction as well as soil erosion, loss of biodiversity and climate change.

Accessible tropical forest areas have virtually all been logged, except for pockets in Amazonia, Central Africa, and remote parts of insular Asia. Much of the remaining forest area in the tropics has increasingly been cleared or transformed into second growth or timber plantations. Over the last century tropical deforestation has been responsible for 125 billion tonnes of carbon into the atmosphere which is over half the amount contributed by fossil fuels combustion. Deforestation is a complex problem stemming from a number of economic, social and ecological factors. Threats to forests are numerous and vary depending on location, but include: commercial logging; clearing for agriculture and grazing, dams, mining, institutional weaknesses, inequitable land distribution, poverty, and in some cases war and civil strife. As a result to many of these threats, seven of the 61 forest protected areas included in this overview have been placed on the List of World Heritage Sites in Danger (Table 7). This suggests that inscription on the World Heritage List does not necessarily guarantee effective stewardship.

Protection for forest areas can be achieved on many scales; from local practices, to national legislation, to international recognition through inscription as a Biosphere Reserve and/or on the World Heritage List. Eighteen of the 61 World Heritage sites included in this overview are also designated Biosphere Reserves, including nine of the 30 tropical forest protected areas. Over the past few years there have been achievements in protecting forests, but the situation facing the earth's forest areas remains a global conservation concern (Table 1). Less than $10 \%$ of the world's remaining forest cover is legally protected. Likewise, a mere $4 \%$ of the remaining tropical moist forests are legally protected, with very iew countries having over $10 \%$ of their tropical moist forests protected. Only Burundi, Singapore, Australia and Sri Lanka have over $50 \%$ of their remaining forests under protection.

Despite advances in the capacity to make a more accurate assessment of the amount and type of forest remaining in the world, statistics on the amount of global 
forests and types of forest remain mere estimates. WCMC and others are in the process of compiling data to gain more precise global data. There are more accurate sources of information regarding the amount/percentage of forest remaining in individual countries or for specific forest types. Whatever the statistics, it is generally agreed that the rate of deforestation is high and that conservation of forest protected areas is a global conservation priority. As "humans" continue to learn more about their demands on the environment, there is an increasing need to inveniory forest areas that have received international protection through the World Heritage Convention. Furthermore, it is important to identify forest areas in the world with minimal protection (gap areas) and list protected forest areas which may merit future nomination on the World Heritage List.

From this overview of 61 forest protected areas inscribed on the World Heritage List, it is clear that there remain several other important forest areas which may be suitable for consideration for World Heritage nomination. A preliminary list of 25 prospective forest protected areas with potential for World Heritage inscription is listed and described in Table 8 . The main criteria used in complying the list of potential forest areas which may merit future nomination for the World Heritage List were the World Heritage Operational Guidelines 43-45, IUCN (Annex 2), IUCN forest program staff and publications reviewing forest protected areas, primarily in regions with minimal World Heritage protection at the present time. This is certainly not an exhaustive list, but is an example of sites located in some of the gap areas currently not represented on the World Heritage List. Omissions of potential sites from Table 9 may not have been due to the lack of forest values, but rather because there were already other forest protected areas inscribed on the World Heritage List located in that particular region.

Upon review of the forest protected areas inscribed on the World Heritage List (Table 1 and the maps), a gap analysis indicates that a limited number of forest protected areas exist on the World Heritage List at the present time within Amazonia (Neotropical Realm), portions of the Indomalayan Realm, the Caribbean (although a forest site in Dominica was nominated and recommended for inscription this year), the boreal regions of the Palearctic Realm, and no sites exist in the Oceanian Realm (Papua New Guinea or the North and South Pacific).

Table 1 lists the 61 forest protected areas which are inscribed on the World Heritage List. Each biogeographical realm is represented except the Oceanian. Otherwise, the division is quite balanced between most of the realms with 10 or more sites located in each the Nearctic (10), Palearctic (14), Afrotropical (13) and Neotropical Realm (11). (Figure 1. and 2). However, these four realms contain 48 of the 61 sites (nearly $80 \%$ ), whereas only 13 sites $(20 \%)$ are located in the four remaining reaims (Figure 1). A biogeographical balance in the location of forest protected areas is not only politically equitable, but is beneficial to maintain a healthy global biodiversity and conservation of flora and fauna species. By inventorying current coverage of forest protected areas on the World Heritage List and identifying gap areas for future nomination, it is hoped to help create a balanced world system of the most outstanding forest protected areas.

Four additional sites (Sundarbans in Bangladesh, Mount Kenya in Kenya, the Nature Reserve El Triunfo in Mexico, and Morne Trois Pitons National Park in 
Dominica) were nominated by the respective State Parties and recommended for inscription by the World Heritage Bureau at the June, 1997 meeting in Paris. If approved by the December, 1997, World Heritage Committee these sites would be included in Table 1 as forest protected areas inscribed on the World Heritage List.

The 61 protected forest areas on the World Heritage List were divided into five forest categories in order to show the range of forest type protected by World Heritage and to indicate which areas may merit future nomination (Tables 2-6). Tropical forest protected areas comprise 30 of the $61(50 \%)$ forest areas inscribed on the World Heritage List (Table 2 and 3 ). These 30 sites contain significant tropical forest cover which was a primary reason for the nomination and inscription of the site on the World Heritage List. 13 tropical forest sites, comprising nearly 13 million ha, are located in the Afrotropical Realm (Figure 4). Although four of the Afrotropical forest sites are located within the Democratic Republic of Congo, nine countries are represented by the 13 sites (Table 2). A diverse distribution is evident in the Neotropical Realm where nine countries are represented by 10 sites (Table 2) and comprise nearly 8 million ha (Figure 4). The Indomalayan Realm has five sites totalling less than a million ha, which is a small proportion of the actual amount of forest within this realm.

Table 2 and 3 indicate the distribution of tropical moist and tropical dry forest protected areas on the World Heritage List. These sites are also listed in Table 1 , but further reveal that 25 sites contain tropical moist forest and 5 sites are tropical dry forest areas. Sub-tropical forest protected areas comprise 7 of the 61 sites and cover less than one million ha of forest protected area from four different biogeographic realms (Table 4). Temperate forest protected areas are better represented with 17 sites on the World Heritage List, 10 of which are located in China and the USA. On the other hand, only six boreal forest protected areas are on the World Heritage List (Table 6), but they cover nearly 17 million ha of forest, the largest of the five forest biomes addressed in this overview. Mention should be made regarding mangrove forest areas on the World Heritage List. The global overview of wetland and marine World Heritage sites identified 15 sites containing mangroves of which seven are included in this overview of forest protected areas on the World Heritage List: Rio Platano Biosphere Reserve (Honduras); Sundarbans (India); Sian Ka'an (Mexico); Darien/Los Katios National Parks (Panama/Colombia; and Kakadu National Park and Fraser Island (Australia). The mangrove forest of these seven sites is mentioned in the site descriptions (Annex 1 ) and is indicated by red shading on each map.

The size distribution of forest protected areas inscribed on the World Heritage List (Figures 2, 3 and 4) are disparate with an expansive range 19.5ha forest in Vallée de Mai Nature Reserve to the nine million ha Lake Baikal. The entire size of the World Heritage site was used in tabulating Figures 2, 3 and 4 instead of merely the amount of forest cover. For example, data shows that one million of ha surround Lake Bakail within the World Heritage site, but the entire nine milion hectares of the site was tabulated in Figures 2 and 3, which is the majority of the 12 million hectares within the Palearctic Realm (Figure 2). In contrast, the six sites within the Indomalayan Realm comprise less than one million hectares. Overall size of the site is shown since it is important to protect a large area of forest in order to include a buffer zone and as much habitat for species diversity as possible within the 
larger protected area. Over $50 \%$ of the sites are a minimum of 100,000 ha with 23 being over 500,000 and 12 over one million ha. Only 2 of the 61 sites are less than 10,000 ha (Figure 3 ). Figure 4 focuses on the 30 tropical forest protected areas on the World Heritage List and shows both the total number of sites within the four tropical realms and the total size (in millions hectares) of the 30 sites.

IUCN welcomes comments on this working paper and suggestions on other potential World Heritage sites. Such comments and information will be useful in preparation of future revisions of this working paper. In an era of the transformation of forests for economic development and agricultural production, the need to protect the world's forests is more important than ever.

\section{Acknowledgements}

We would like to acknowledge the assistance of Natarajan Ishwaran of UNESCO World Heritage Centre; Jim Paine, Simon Blyth and Corrina Ravilious of WCMC; and Maryse Mahy of Ramsar for translation of the executive summary into French. We also acknowledge the assistance of Jeff McNeely, Simon Rietbergen and Andrea Finger-Stich, of IUCN; the WWF forest program staff; and the Australian Department of Environment for their generous support towards the production of this document. 
. 
TABLES AND FIGURES 



\section{TABLE 1}

\section{Forest Protected Areas on the World Heritage List}

\section{NEARCTIC REALM CANADA \\ CANADA \\ CANADA \\ CANADA \\ CANADA \& USA \\ USA \\ USA \\ USA \\ USA \\ USA}

\section{PALEARCTIC REALM}

BELARUS/POLAND

BULGARIA

CHINA

CHINA

CHINA

CHINA

CHINA

CROATIA

JAPAN

JAPAN

RUSSIAN FEDERATION

RUSSIAN FEDERATION

SPAIN

YUGOSLAVIA

\section{AFROTROPICAL REALM}

CAMEROON

COTE DE'IVOIRE

COTE D'IVOIREIGUINEA

DEM. REPUBLIC OF CONGO

DEM. REPUBLIC OF CONGO

DEM. REPUBLIC OF CONGO

DEM. REPUBLIC OF CONGO

MADAGASCAR

SENEGAL

SEYCHELLES

TANZANIA

UGANDA

UGANDA

\section{INDOMALAYAN REALM}

INDIA

INDONESIA

INDIA

NEPAL

SRI LANKA

THAILAND

\author{
Canadian Rocky Mountain Parks \\ Gros Morne National Park \\ Nahanni National Park \\ Wood Buffalo National Park \\ Waterton Glacier International Peace Park \\ Great Smoky Mountains National Park \\ Olympic National Park \\ Redwood National Park \\ "Yellowstone National Park \\ Yosemite National Park USA
}

\author{
Beloveshskaya Pushcha/Bialowieza Forest \\ Pirin National Park \\ Huanglong Scenic and Historic Interest Area \\ Jiuzhaigou Valley Scenic and Historic Interest Area \\ Mount Emei \\ Huangshan \\ Taishan \\ *Plitvice Lakes National Park \\ Shirakami-Sanchi \\ Yakushima (Yaku-Island) \\ Lake Baikal \\ Virgin Komi Forests \\ Garajonay National Park \\ Durmitor National Park
}

\author{
Dja Faunal Reserve \\ Tai National Park \\ *Mount Nimba Strict Nature Reserve \\ Kahuzi-Biega National Park \\ Okapi Faunal Reserve \\ Salonga National Park \\ -Virunga National Park \\ Tsingy de Bemaraha Strict Nature Reserve \\ Niokolo-Koba National Park \\ Valée de Mai Nature Reserve \\ Selous Game Reserve \\ Bwindi Impenetrable Forest National Park \\ Rwenzori Mountains National Park
}

\author{
*Manas National Park \\ Ujung Kulon National Park \\ Sundarbans National Park \\ Royal Chitwan National Park \\ Sinharaja Forest Reserve \\ Thungyai - Huai Kha Khaeng Wildlife Sanctuaries
}

* These sites are also included on the List of World Heritage in Danger (Table 7).

(CONTINUED ON NEXT PAGE) 


\section{ANTARCTIC REALM}

NEW ZEALAND

NEW ZEALAND

\section{AUSTRALIAN REALM}

AUSTRALIA

AUSTRALIA

AUSTRALIA

AUSTRALIA

AUSTRALIA

NEOTROPICAL REALM

ARGENTINAIBRAZIL

COSTA RICAIPANAMA

ECUADOR

GUATEMALA

HONDURAS

MEXICO

PANAMA /COLOMBIA

PERU

PERU

PERU

VENEZUELA
Te Wahipounamu - South West New Zealand

Tongariro National Park

Central Eastern Australian Rainforests

Fraser Island

Kakadu National Park

Tasmanian Wilderness

Wet Tropics of Queensland

Iguazú and Iguaçu National Parks

Talamanca Range \& La Amistad Reserves

-Sangay National Park

Tikal National Park

*Rio Platano Biosphere Reserve

Sian Ka'an Biosphere Reserve

Darien and Los Katios National Parks

Historic Sanctuary of Machu Picchu

Manu National Park

Rio Abiseo National Park

Canaima National Park

* These seven sites are also included on the List of World Heritage in Danger (Table 7)

The Sundarbans (Bangladesh), Morne Trois Pitons National Park (Dominica), Mount Kenya (Kenya), and The Nature Reserve EI Triunfo (Mexico) were nominated in 1997 for inscription on the World Heritage List. If approved by the December, 1997, Committee these sites would be included in Table 1 as forest protected areas inscribed on the World Heritage List. 


\section{TABLE 2}

\section{Tropical Moist Forest Protected Areas on the World Heritage List}

Site numbers are listed for ease of reference to detailed information in Annex and maps

AUSTRALIA
CAMEROON
COSTA RICAIPANAMA
COTE D'IVOIRE
COTE D'IVOIRE/GUIN
DEM. REPUBLIC OF CO
DEM. REPUBLIC OF CO
DEM. REPUBLIC OF COI
DEM. REPUBLIC OF COI
ECUADOR
GUATEMALA
HONDURAS
INDIA
INDONESIA
MEXICO
PANAMAVOLOMBIA
PERU
PERU
PERU
SEYCHELLES
SRI LANKA
UGANDA
UGANDA
VENEZUELA

50. Wet Tropics of Queensland

25. Dja Faunal Reserve

52. Talamanca Range and La Amistad Reserves

26. Tai National Park

27. Mount Nimba Strict Nature Reserve

28. Kahuzi-Biega National Park

29. Okapi Faunal Reserve

30. Salonga National Park

31. Virunga National Park

53. Sangay National Park

54. Tikal National Park

55. Rio Platano Biosphere Reserve

40. Sundarbans National Park

39. Ujung Kulon National Park

56. Sian Ka'an Biosphere Reserve

57. Darien and Los Katios National Parks

58. Historic Sanctuary of Machu Picchu

59. Manu National Park

60. Rio Abiseo National Park

34. Vallée de Mai Nature Reserve

42. Sinharaja Forest Reserve

36. Bwindi Impenetrable Forest National Park

37. Rwenzori Mountains National Park

61. Canaima National Park 


\section{TABLE 3}

\section{Tropical Dry Forest Protected Areas on the World Heritage List}

Site numbers are listed for ease of reference to detailed information in Annex and maps

AUSTRALIA

INDIA

MADAGASCAR

REPUBLIC OF TANZANIA

SENEGAL

THAILAND
47. Kakadu National Park

37. Manas Wildlife Sanctuary

31. Tsingy de Bemaraha Strict Nature Reserve

34. Selous Game Reserve

32. Niokolo-Koba National Park

42. Thungyai - Huai Kha Khaeng Wildlife Sanctuaries

\section{TABLE 4}

\section{Sub-Tropical Forest Protected Areas on the World Heritage List}

Site numbers are listed for ease of reference to detailed information in Annex and maps

\section{ARGENTINAIBRAZIL}

AUSTRALIA

AUSTRALIA

CHINA

JAPAN

JAPAN

SPAIN
51. Iguacu and Iguazu National Parks

46. Central Eastern Australian Rainforests

47. Fraser Island

15. Mt. Emei

19. Shirakami - Sanchi

20. Yakushima (Yaku - Island)

23. Garajonay National Park 


\section{Temperate Forest Protected Areas on the World Heritage List}

Site numbers are listed for ease of reference to detailed information in Annex and maps

AUSTRALIA
BELARUS/POLAND
BULGARIA
CHINA
CHINA
CHINA
CHINA
CROATIA
NEPAL
NEW ZEALAND
NEW ZEALAND
USA
USA
USA
USA
USA
YUGOSLAVIA
49. Tasmanian Wilderness
11. Beloveshskaya Pushcha/Bialowieza Forest
12. Pirin National Park
13. Huanglong Scenic and Historic Interest Area
14. Jiuzhaigou Valley Scenic and Historic Interest Area
16. Huangshan
17. Taishan
18. Plitvice Lakes National Park
41. Royal Chitwan National Park
44 Te Wahipounamu
45. Tongariro National Park
6. Great Smoky Mountains National Park
7. Olympic National Park
8. Redwood National Park
9. Yellowstone National Park
10. Yosemite National Park
24. Durmitor National Park

\section{TABLE 6}

\section{Boreal Forest Protected Areas Inscribed on the World Heritage List}

Site numbers are listed for ease of reference to detailed information in Annex and maps

CANADA

CANADA

CANADA

CANADA

CANADAUSA

RUSSIAN FEDERATION

RUSSIAN FEDERATION
1. Canadian Rocky Mountain Parks

2. Gros Morne National Park

3. Nahanni National Park

4. Wood Buffalo National Park

-5. Waterton takes Gtacier tntemational Peace Park

21. Lake Baikal

22. Virgin Komi Forests 


\section{Forest Protected Areas Inscribed on the List of World Heritage Sites in Danger}

\begin{tabular}{|c|c|c|c|c|}
\hline SITE & COUNTRY & $\begin{array}{l}\text { DANGER } \\
\text { LIST }\end{array}$ & FOREST VALUES & THREATS \\
\hline 1. Plitvice Lakes & Croatia & 1991 & $\begin{array}{l}70 \% \text { of site is forested, } \\
\text { last remaining stands of } \\
\text { pure beech in Europe, } \\
\text { spruce, fir, pine, juniper, } \\
\text { black alder, maple, } \\
\text { sumac, bears, wolves, } \\
\text { threatened bird species }\end{array}$ & $\begin{array}{l}\text { military occupation, } \\
\text { civil unrest }\end{array}$ \\
\hline 2. Sangay & Ecuador & 1992 & $\begin{array}{l}\text { high diverse natural } \\
\text { habitat, tropical mist } \\
\text { forest, subtropical rain } \\
\text { forest ( } 40 \mathrm{~m} \text { canopy), } \\
\text { cedro, aliso, palms, } \\
\text { cloud forests, bamboo, } \\
\text { low montane rain forests }\end{array}$ & $\begin{array}{l}\text { human encroachment, } \\
\text { poaching, } \\
\text { illegal livestock grazing, } \\
\text { potential road construction }\end{array}$ \\
\hline 3. Mount Nimba & $\begin{array}{l}\text { Cote } \\
\text { d'Ivoire \& } \\
\text { Guinea }\end{array}$ & 1992 & $\begin{array}{l}\text { high altitude, gallery and } \\
\text { dense forest rich in flora } \\
\text { with over } 2,000 \text { plant } \\
\text { species ( } 16 \text { endemic), } \\
\text { epiphytes, tree ferns }\end{array}$ & $\begin{array}{l}\text { influx of refugees, } \\
\text { proposed iron-ore mining, } \\
\text { site boundary confusion, } \\
\text { proposal to reduce site size }\end{array}$ \\
\hline 4. Manas & India & 1992 & $\begin{array}{l}\text { tropical rain, tropical } \\
\text { dense semi-evergreen, } \\
\text { and dry deciduous } \\
\text { forests, most diverse } \\
\text { wildlife reserve in India, } \\
\text { expansive tiger reserve. }\end{array}$ & $\begin{array}{l}\text { civil unrest, } \\
\text { commercial poaching, } \\
\text { political instability, } \\
\text { habitat destruction, } \\
\text { limited resources, } \\
\text { management restricted }\end{array}$ \\
\hline 5. Virunga & $\begin{array}{l}\text { Democratic } \\
\text { Rep.Congo }\end{array}$ & 1994 & $\begin{array}{l}\text { diverse forest habitats, } \\
\text { including tropical rain, } \\
\text { alpine, eastern steppe, } \\
\text { bamboo, equatorial, } \\
\text { swamp, and dry thick } \\
\text { forests on lava plains, } \\
\text { wooded savannah }\end{array}$ & $\begin{array}{l}\text { civil unrest, } \\
\text { refugee impact, } \\
\text { commercial poaching, } \\
\text { human encroachment and } \\
\text { demand for food and fuel, } \\
\text { donors suspended aid, } \\
\text { restrictions on management }\end{array}$ \\
\hline 6. Yellowstone & USA & 1995 & $\begin{array}{l}80 \% \text { of site is forested } \\
\text { with lodgepole pine } \\
\text { Pinus contorta being the } \\
\text { most abundant, total of } \\
\text { seven coniferous tree } \\
\text { species in park }\end{array}$ & $\begin{array}{l}\text { mining operations, } \\
\text { water pollution, } \\
\text { sewage leakage, } \\
\text { waste contamination, } \\
\text { disease impact on bison, } \\
\text { tourism }\end{array}$ \\
\hline 7. Rio Platano & Honduras & 1996 & $\begin{array}{l}90 \% \text { tropical humid rain } \\
\text { forest, largest surviving } \\
\text { virgin rain forest area in } \\
\text { Honduras, mangroves, } \\
\text { pine savannahs, swamp } \\
\text { and hardwood gallery } \\
\text { forest, palm, cedar, } \\
\text { bamboo, mahogany }\end{array}$ & $\begin{array}{l}\text { agricultural expansion, } \\
\text { human encroachment, } \\
\text { commercial poaching, } \\
\text { introduced species, } \\
\text { over fishing, } \\
\text { social conflict, } \\
\text { poor infrastructure, } \\
\text { inadequate management }\end{array}$ \\
\hline
\end{tabular}

Nb. Both Kahuzi-Biega National Park and Okapi Faunal Reserve are being proposed as additions to the Danger List in 1997. 


\section{FORESTED PROTECTED AREAS WHICH MAY MERIT CONSIDERATION FOR WORLD HERITAGE NOMINATION}

- This is not an exhaustive list, but an illustration of forest protected areas which may merit consideration for nomination on the World Heritage List.

AREA

COUNTRY

MAIN NATURAL VALUES

\begin{tabular}{|c|c|c|}
\hline \multicolumn{3}{|l|}{ NEARCTIC } \\
\hline 1. South Moresby NP & CANADA & $\begin{array}{l}147,000 \text { ha temperate rainforest area on the south end } \\
\text { of Queen Charlotte Islands in British Columbia; } \\
\text { Despite extensive logging in surrounding areas, S. } \\
\text { Moresby was protected in } 1988 \text { through efforts of local } \\
\text { Haida people and Islands Protection Society. } \\
\text { Consists of hemlock, other temperate tree species } \\
\text { and endemic flora and fauna (blacktail deer). }\end{array}$ \\
\hline $\begin{array}{l}\text { 2. Volcan Nevado de } \\
\text { Colima National Park }\end{array}$ & MEXICO & $\begin{array}{l}22,000 \text { ha dry pine forest in west, central Mexico; high } \\
\text { biodiversity - Mexico contains } 10 \% \text { of world's } \\
\text { terrestrial vertebrates }(1352) \text { and plant }(25,000) \\
\text { species. }\end{array}$ \\
\hline $\begin{array}{l}\text { 3. Kalimiopsis Widderness } \\
\text { and Siskiyou Region }\end{array}$ & USA & $\begin{array}{l}\text { Over } 5 \text { million ha wilderness area known for its } \\
\text { extensive biodiversity ( } 3500 \text { flora species) and forest } \\
\text { habitat; coniferous and mixed evergreen forests; } \\
\text { unique landscape of canyons, perodotite, volcanic } \\
\text { debris, ophioliote crust, rock ridges, and three wild } \\
\text { and scenic rivers; named after a unique pre-ice age } \\
\text { shrub, the Kalimiopsis contains over } 100 \text { coniferous } \\
\text { and hardwood tree species (madrone, pine, fir, cedar, } \\
\text { spruce and } 5 \text { sensitive species) and over } 200 \\
\text { herbaceous plants and ferns - many endemic and } \\
\text { sensitive; one of largest roadless areas in the U.S. }\end{array}$ \\
\hline \multicolumn{3}{|l|}{ PALEARCTIC } \\
\hline $\begin{array}{l}\text { 4. Carpathian Forest } \\
\text { Reserve and NP }\end{array}$ & UKRAINE & $\begin{array}{l}20,000 \text { ha protected forest area in Zakarpatska region; } \\
\text { covers only } 4 \% \text { of the country, but contains } 33 \% \text { of the } \\
\text { Ukraine's forest resources, over } 50 \% \text { of plant species } \\
\text { ( } 2110 \text { total) and highest forest concentration area } \\
\text { ( } 53 \% \text { of region is forest); severe threats have } \\
\text { endangered the area, but structural changes are } \\
\text { planned to promote the Carpathians as a recreation } \\
\text { zone to reduce the industrial impact; recent projects } \\
\text { funded by GEF, the MacArthur Foundation and the } \\
\text { World Bank for conservation biodiversity. }\end{array}$ \\
\hline \multicolumn{3}{|l|}{ AFROTROPICAL } \\
\hline 5. Korup National Park & CAMEROON & $\begin{array}{l}126,000 \text { ha Biosphere Reserve; contains much of } \\
\text { Cameroon's tropical moist and lowland evergreen } \\
\text { rainforest with over } 3500 \text { flora species; sustainable } \\
\text { forestry and community development project. }\end{array}$ \\
\hline 6. West Gabon Complex & GABON & $\begin{array}{l}\text { Expansive tropical lowland \& hill rainforest; habitat for } \\
\text { baboon, mandrill, colobus monkeys; home to Baka } \\
\text { people; numerous flora, fauna and protected areas } \\
\text { including Ipassa Makokou ( } 15,000 \text { ha Bio Reserve). }\end{array}$ \\
\hline $\begin{array}{l}\text { 7. Montagne D'Ambre } \\
\text { Protected Areas }\end{array}$ & MADAGASCAR & $\begin{array}{l}\text { Four protected areas in north Madagascar; tropical dry } \\
\text { and moist evergreen forest; one of country's richest } \\
\text { areas of biodiversity and ecological diversity; transition } \\
\text { zone between dry deciduous and eastern moist forest } \\
\text { permits a species rich transition zone with high } \\
\text { endemism, karstic pinnacles, caves, etc.; rivers are } \\
\text { only year round water source for local people. }\end{array}$ \\
\hline
\end{tabular}




\begin{tabular}{|c|c|c|}
\hline AREA & COUNTRY & MAIN NATURAL VALUES \\
\hline \multicolumn{3}{|l|}{ INDOMALAY } \\
\hline $\begin{array}{l}\text { 8. Andaman Island } \\
\text { Protected Areas }\end{array}$ & INDIA & $\begin{array}{l}\text { Six national parks and } 94 \text { wildlife sanctuaries on } \\
\text { Andaman and Nicobar islands covering } 70,800 \text { ha; } \\
\text { tropical evergreen, semi-evergreen, moist deciduous, } \\
\text { beach, bamboo and mangrove forests; high rate of } \\
\text { biodiversity of flora species, esp. on Andaman. }\end{array}$ \\
\hline 9. Western Ghats & INDIA & $\begin{array}{l}\text { Over } 15 \text { million ha area with eight national parks and } \\
39 \text { wildlife sanctuaries; moist evergreen forest across } \\
\text { mountain range; rich in species diversity ( } 84 \text { of India's } \\
112 \text { endemic amphibians); monkeys, squirreis and } \\
\text { bats live in tree canopy; deer and elephants browse in } \\
\text { lower branches and understorey; clear felling was } \\
\text { stopped in mountainous areas by Chipko movement. }\end{array}$ \\
\hline 10. Gunung Leuser NP & $\begin{array}{l}\text { INDONESIA } \\
\text { (SUMATRA) }\end{array}$ & $\begin{array}{l}\text { one of largest tropical rain forests protected areas in } \\
\text { Indonesia ( } 835,500 \text { ha); montane, swamp, subalpine } \\
\text { and lowland dipterocarp rain forest; over } 2000 \text { flora } \\
\text { species; Biosphere Reserve, ecosystem development } \\
\text { project and Orang-utan Rehab Centre (orang-utans, } \\
\text { gibbons, tigers, monkeys, elephants, leopards, } \\
\text { Sumatran rhino); waterfalls, hot springs, volcanic rock. }\end{array}$ \\
\hline 11. Kutai Game Reserve & $\begin{array}{l}\text { INDONESIA } \\
\text { (KALIMANTAN) }\end{array}$ & $\begin{array}{l}200,000 \text { ha Biosphere reserve is best example of } \\
\text { tropical rainforest on Kalimantan one of Southeast } \\
\text { Asia's largest lowland montane rainforests; } 262 \\
\text { dipterocarps and } 83 \% \text { of Borneo's forest species. }\end{array}$ \\
\hline $\begin{array}{l}\text { 12. Irian Jaya Tropical } \\
\text { Forest Protected Areas }\end{array}$ & IRIAN JAYA & $\begin{array}{l}\text { Irian Jaya is one of the largest expanses of pristine } \\
\text { tropical rainforest ( } 35 \text { million ha) in Southeast Asia; } \\
\text { lower montane forests occur below } 3000 \mathrm{~m} \text { and upper } \\
\text { montane and subalpine forest above } 3400 \mathrm{~m} \text {; swamp, } \\
\text { eucalyptus, beach, and mangrove ( } 2 \text { nd largest behind } \\
\text { Sundarbans) forest; sago palm is staple foodsource; } \\
\text { two national parks and seven nature/game reserves. }\end{array}$ \\
\hline 13. Gunung Mulu NP & $\begin{array}{l}\text { MALAYSIA } \\
\text { (SARAWAK) }\end{array}$ & $\begin{array}{l}52,900 \text { ha protected area with expansive tropical } \\
\text { lowland montane rainforest; } 2371 \mathrm{~m} \text { Mt. Mulu; } \\
\text { limestone massif; high endemism and biodiversity of } \\
\text { flora and fauna; inhabited by Penan peoples. }\end{array}$ \\
\hline 14. Kinabulu NP & $\begin{array}{l}\text { MALAYSIA } \\
\text { (SABAH) }\end{array}$ & $\begin{array}{l}75,400 \text { ha park north Sabah; lowland montane tropical } \\
\text { rainforest; high biodiversity with } 75 \text { of Borneo's } 135 \\
\text { ficus species ( } 13 \text { endemic), and } 72 \text { Fagaceae species; } \\
25 \% \text { of fauna species are endemic, } 290 \text { species of } \\
\text { butterfly and moth; } 4094 \mathrm{~m} \text { Mt. Kinabulu. }\end{array}$ \\
\hline 15. Taman Negara NP & $\begin{array}{l}\text { MALAYSIA } \\
\text { (PENISULA) }\end{array}$ & $\begin{array}{l}434,000 \text { ha area is one of largest tropical rainforest } \\
\text { reserves in Southeast Asia; lowland montane } \\
\text { evergreen rainforest, high biodiversity with over } 2000 \\
\text { flora species; } 2189 \mathrm{~m} \text { Mt. Tahan (highest point on } \\
\text { Peninsula); dam project was thwarted in 1970's. }\end{array}$ \\
\hline $\begin{array}{l}\text { 16. Southern Laos } \\
\text { Tropical Forest Reserves }\end{array}$ & 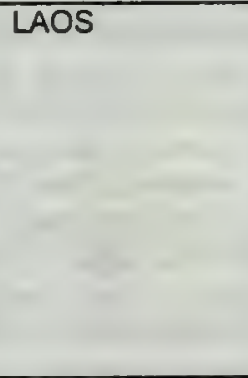 & $\begin{array}{l}\text { Most extensive undisturbed tropical evergreen forest } \\
\text { region in Laos; , the lowland tropical forest of Belovens } \\
\text { Plateau ( } 80,000 \text { ha) Xe Piane }(15,000 \mathrm{ha}) \text { and Bung } \\
\text { Nong Ngom National Parks have been identified as } \\
\text { priority areas for conservation and consist of dense } \\
\text { evergreen and semi-evergreen monsoon forests and } \\
\text { open deciduous forest in flatter areas; numerous flora } \\
\text { and fauna including threatened black gibbon, clouded } \\
\text { leopard, tiger, Asian elephant and kouprey; proposed } \\
\text { transborder site with Vietnam, Cambodia and Laos. }\end{array}$ \\
\hline 17. St. Paul National Park & PHILLIPINES & $\begin{array}{l}5,800 \text { ha park on north portion of Puerto Princesa } \\
\text { Island; montane rainforest; subterranean river; high } \\
\text { rate of endemism in plants, fungi, birds and reptiles. }\end{array}$ \\
\hline
\end{tabular}




\begin{tabular}{|c|c|c|}
\hline AREA & COUNTRY & MAIN NATURAL VALUE \\
\hline $\begin{array}{l}\text { 18. Horton Plains and } \\
\text { Peak Wilderness }\end{array}$ & SRI LANKA & $\begin{array}{l}\text { Remote plateau is Sri Lanka's largest relatively } \\
\text { undisturbed montane forest and habitat for many } \\
\text { endemic flora and fauna species; the Peak Wilderness } \\
\text { is a unique facet of nature of low dense and slow } \\
\text { growing forest trees, a stunted species of } \\
\text { clustracene(Keena) with its crown interlocked in a web } \\
\text { of leaves; foliage of Horton Plains include species } \\
\text { such as Rhododendron and magnolia; underlayer of } \\
\text { forest has smaller trees and plants. }\end{array}$ \\
\hline \multicolumn{3}{|l|}{ AUSTRALIAVOCEANIAN } \\
\hline 19. Rennell Islands & $\begin{array}{l}\text { SOLOMON } \\
\text { ISLANDS }\end{array}$ & $\begin{array}{l}\text { Largest coral atoll in the world ( } 86 \times 15 \mathrm{~km} \text { ) is mostly } \\
\text { covered by dense forest with a } 20 \mathrm{~m} \text { tall average } \\
\text { canopy with numerous larger remergent trees; } \\
\text { numerous endemic flora and fauna species ( } 40 \% \text { of } \\
\text { birds); over } 20 \text { orchid species; limestone karsts; } \\
\text { andiargest lake in South Pacific (Lake Tungano). }\end{array}$ \\
\hline 20. Le Popu-Pue NP & $\begin{array}{l}\text { WESTERN } \\
\text { SAMOA }\end{array}$ & $\begin{array}{l}\text { Extending from central mountains to coast of Opula } \\
\text { Island, this park is the best remaining tract of tropical } \\
\text { rainforest in Samoa; only } 2,857 \text { ha in size, but relative } \\
\text { to size of island and two other rainforest reserves in } \\
\text { W. Samoa (Falealupo and Tafua) comprise } 7,000 \text { ha. }\end{array}$ \\
\hline \multicolumn{3}{|l|}{ NEOTROPICAL } \\
\hline $\begin{array}{l}\text { 21. Bolivian Amazon } \\
\text { Basin Protected Areas }\end{array}$ & BOLIVIA & $\begin{array}{l}\text { Amazonian basin and lowlands of Bolivia are } \\
\text { characterised by extensive areas of lowland moist } \\
\text { forest and seasonally inundated savannahs; these } \\
\text { open landscapes are traversed by numerous } \\
\text { rivers bordered by dense gallery forests; within the } \\
\text { savannahs, numerous forest islands dot the horizon } \\
\text { providing habitat for the maned wolf, giant anteater, } \\
\text { Amazon river dolphin and some of the highest } \\
\text { concentration of plant species in the world. Protected } \\
\text { areas include the Beni Biosphere Reserve (1.3 million } \\
\text { ha), Isoiboro Secure ( } 1.1 \text { million ha) and others. }\end{array}$ \\
\hline 22. Jau National Park & BRASIL & $\begin{array}{l}2.2 \text { million ha park in Northwest Amazonia; extensive } \\
\text { lowland moist tropical and dense evergreen forest; } \\
\text { complex variety of forest features including vines, } \\
\text { palms, diverse forest species, and numerous } \\
\text { vegetation types in the understorey; "centres of } \\
\text { endemism" and high rate of threatened species. }\end{array}$ \\
\hline 23. Xingu National Park & BRASIL & $\begin{array}{l}2.2 \text { million protected area in Maro Grosso, lower } \\
\text { Amazonia ( } 2^{\text {nd }} \text { largest park in Brasil behind Jau); } \\
\text { extensive lowland moist tropical forest and river } \\
\text { system; complex vegetation and high endemism. }\end{array}$ \\
\hline $\begin{array}{l}\text { 24. Serraniade de } \\
\text { Macarena }\end{array}$ & COLOMBIA & $\begin{array}{l}630,000 \text { ha park in central Colombia; lowland moist, } \\
\text { submontane and montane tropical forest; } \\
\text { aesthetic beauty in Caño Cristales and stream areas } \\
\text { of the buffer zone, vegetation, petroglyphs, Tablazo } \\
\text { ridge, Guayabero canyon, and rapids of Angosturas. }\end{array}$ \\
\hline $\begin{array}{l}\text { 25. Sierra Nevada de } \\
\text { Santa Marta BR }\end{array}$ & COLOMBIA & $\begin{array}{l}\text { Over } 1.5 \text { million ha area in the Cordillera Central, the } \\
\text { highest coastal range of mountains in Colombia; rich } \\
\text { variety of flora and fauna in the dense rain forest } \\
\text { covering the northern slopes; southern slopes are } \\
\text { drier; inhabited by the Kogi and Arhuaco Indians; } \\
\text { there are no continuous forest above } 1,200 \mathrm{~m} \text {, but } \\
\text { trees grow along the rivers up to } 1,700 \mathrm{~m} \text { and provide } \\
\text { habitat for numerous flora and bird ( } 15 \text { endemic) } \\
\text { species, especially at higher altitudes. }\end{array}$ \\
\hline
\end{tabular}




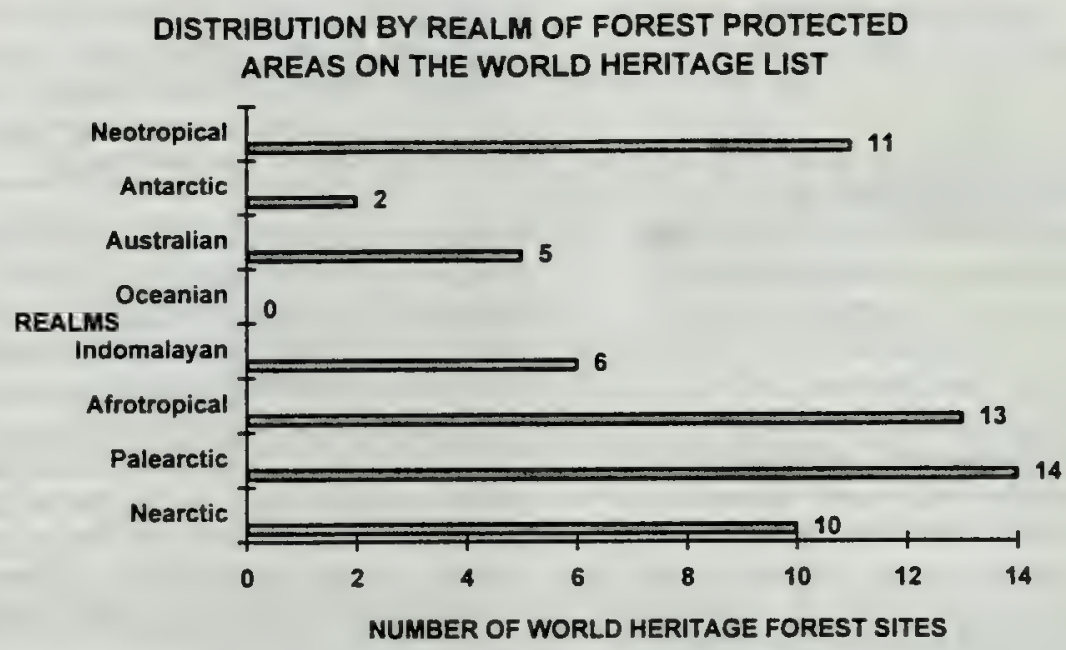

FIGURE 2

TOTAL SIZE OF WORLD HERITAGE SITES WITH FOREST PROTECTED AREAS BY EACH BIOGEOGRAPHIC REALM

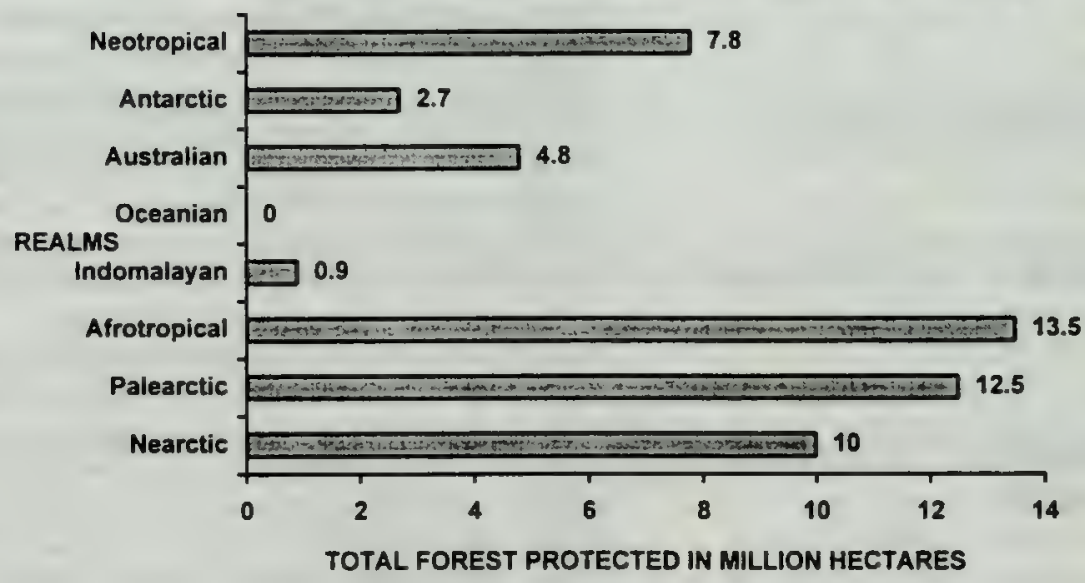


FIGURE 3

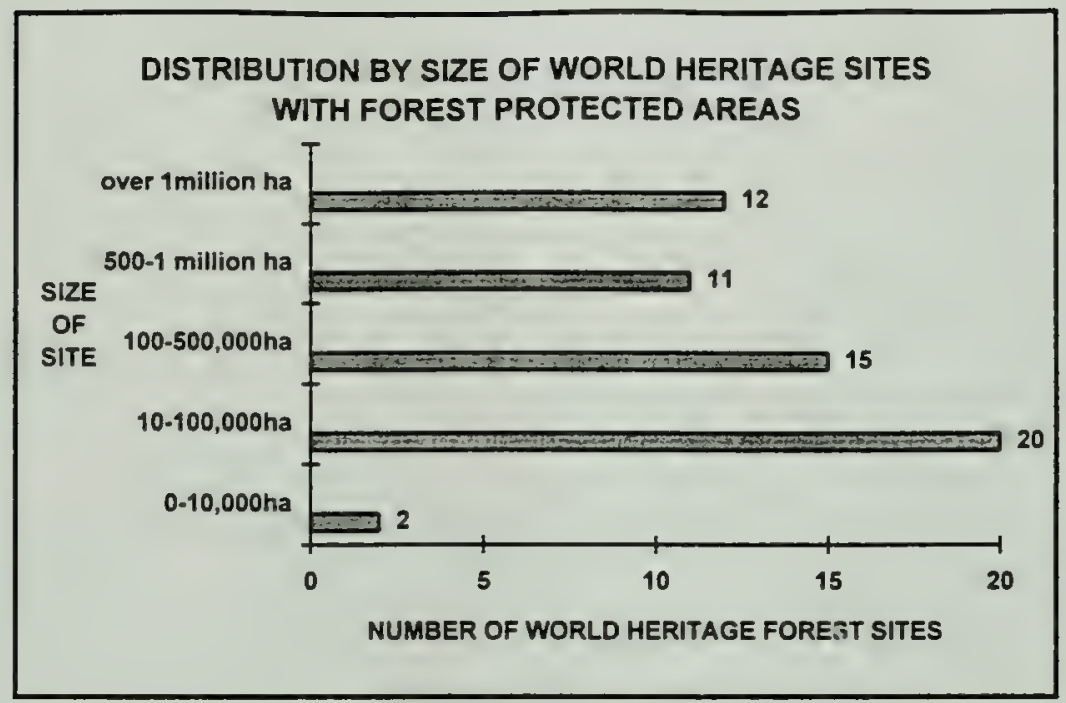

FIGURE 4

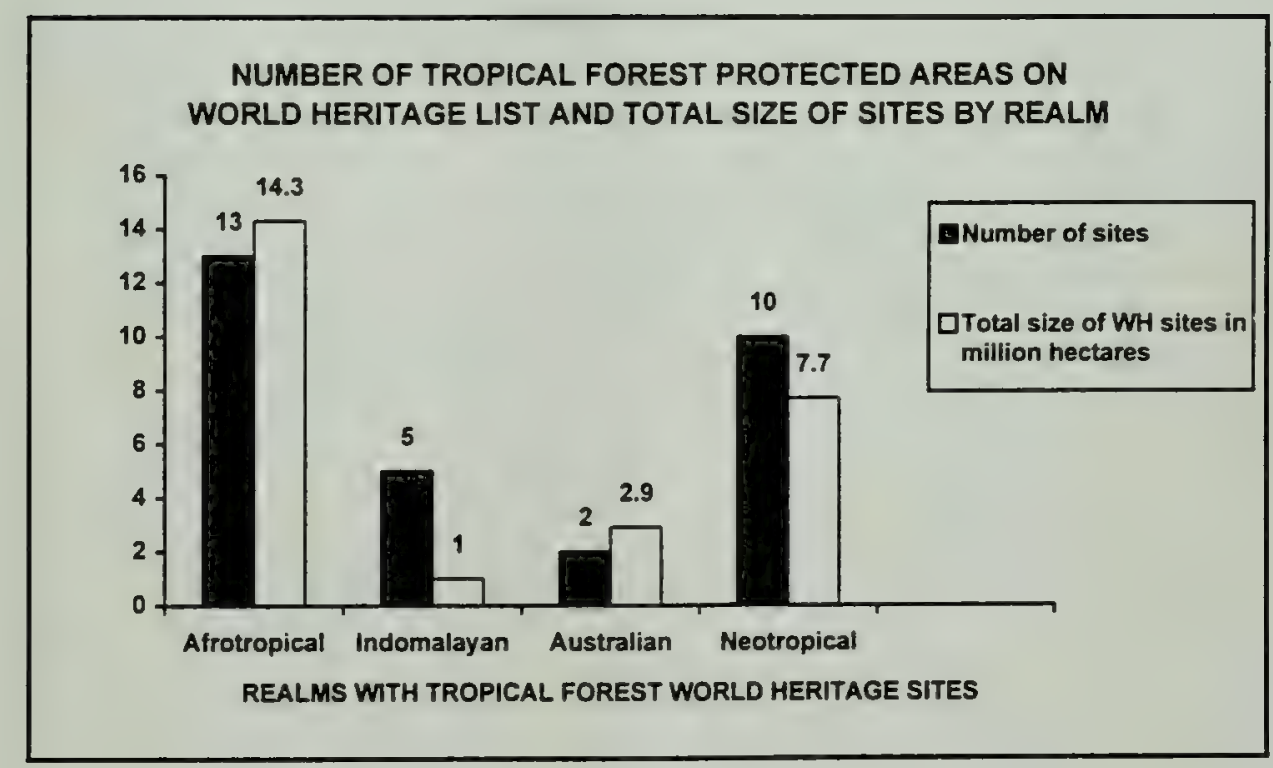



MAPS 



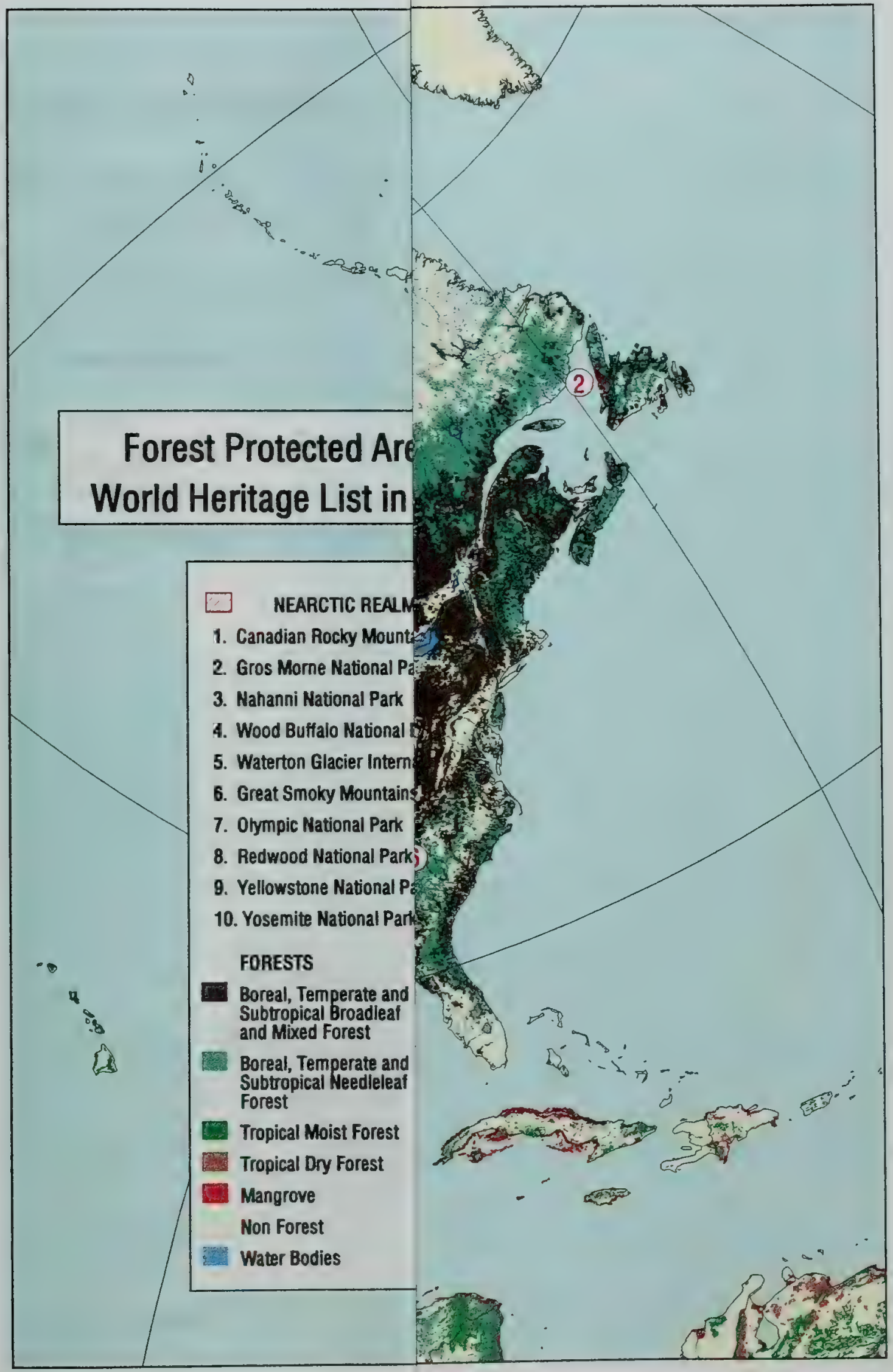




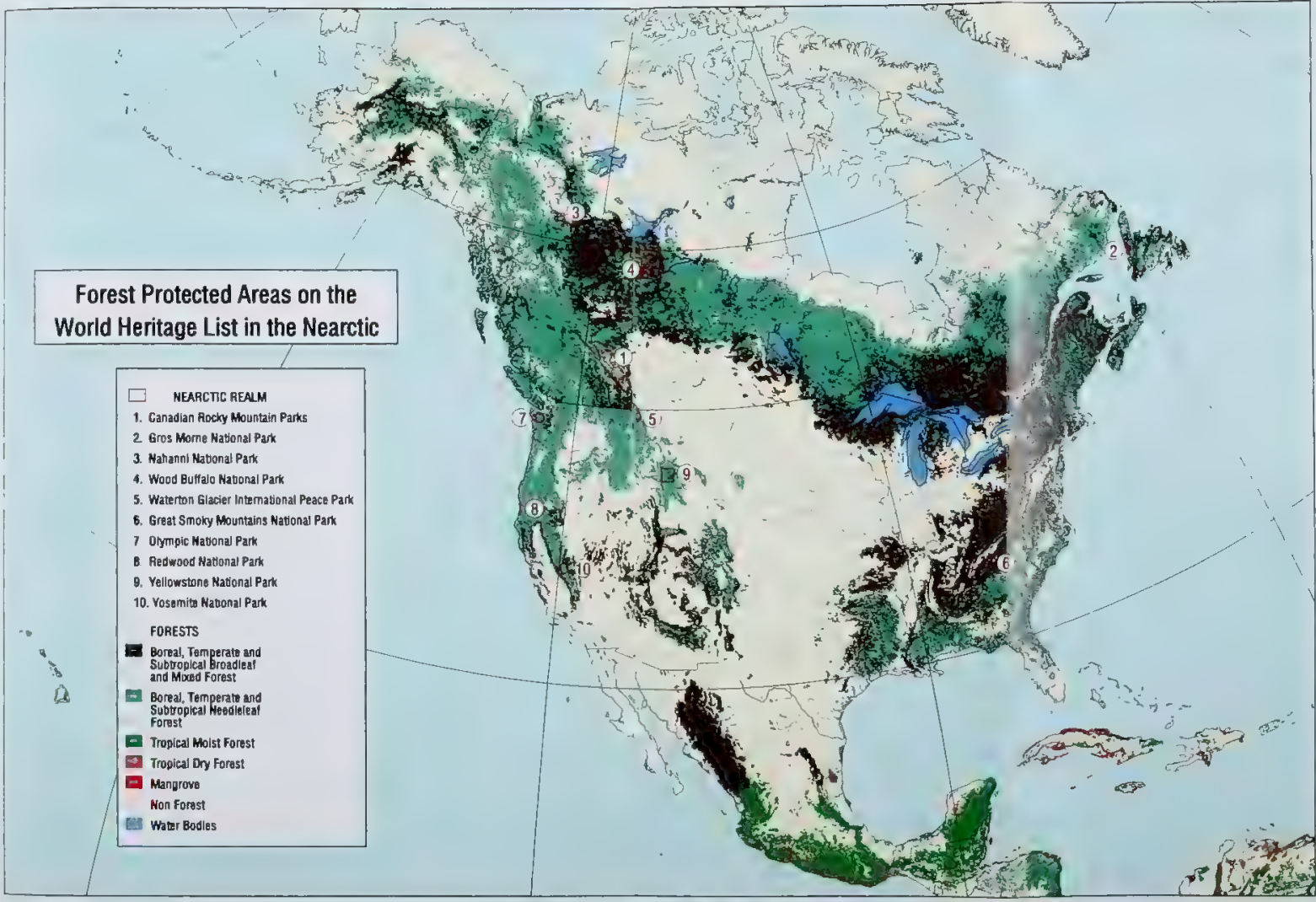




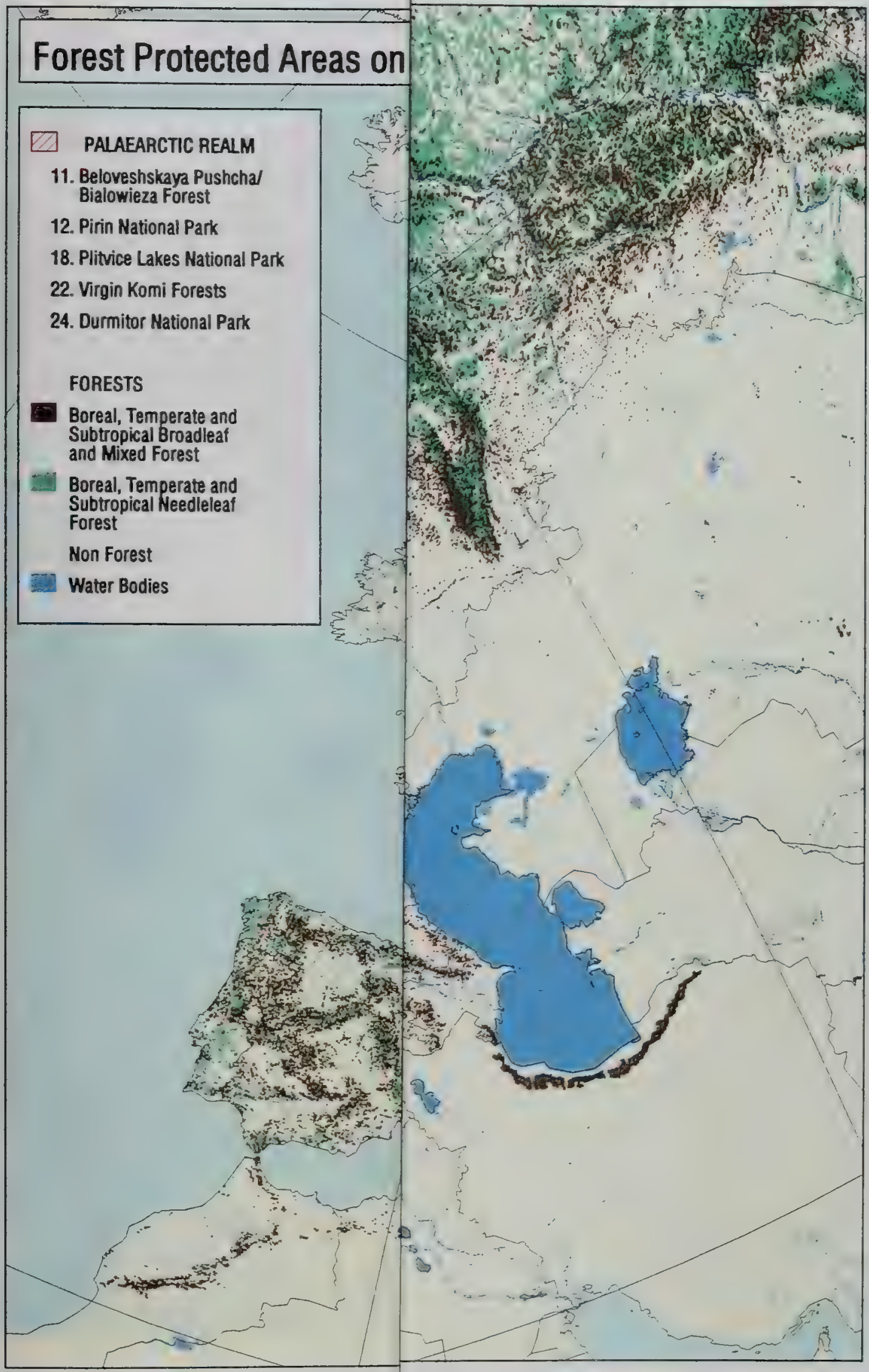




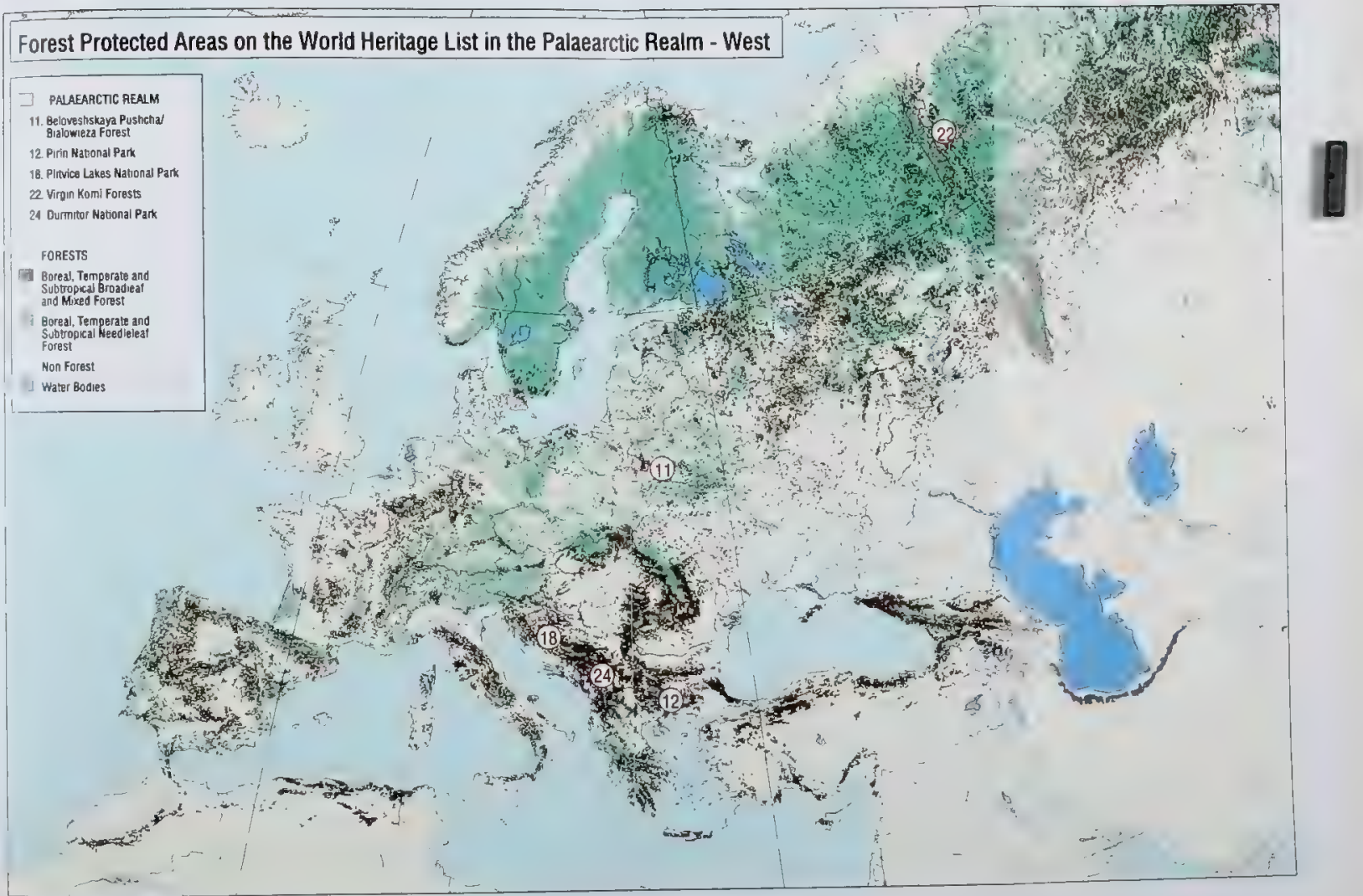




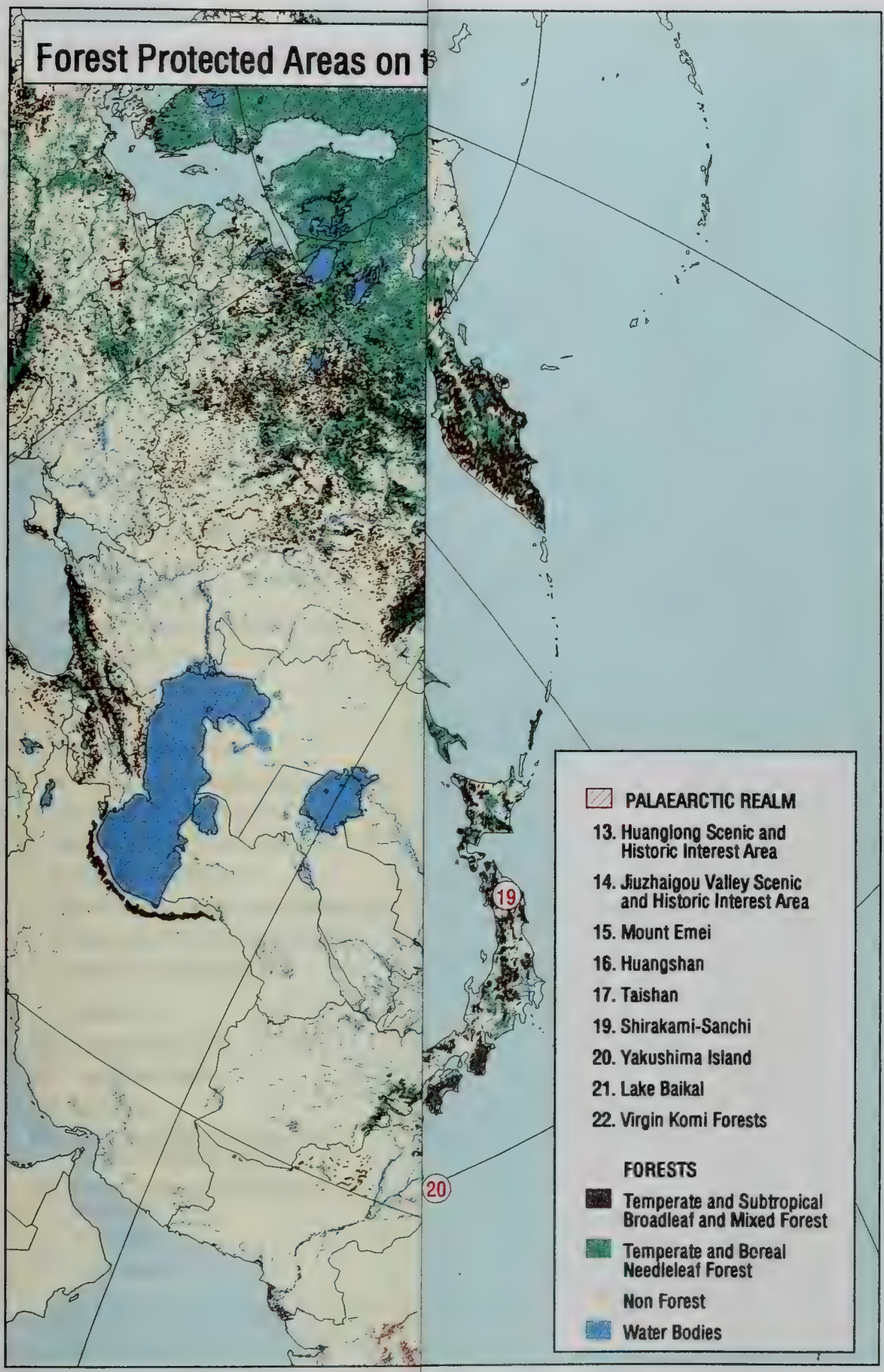




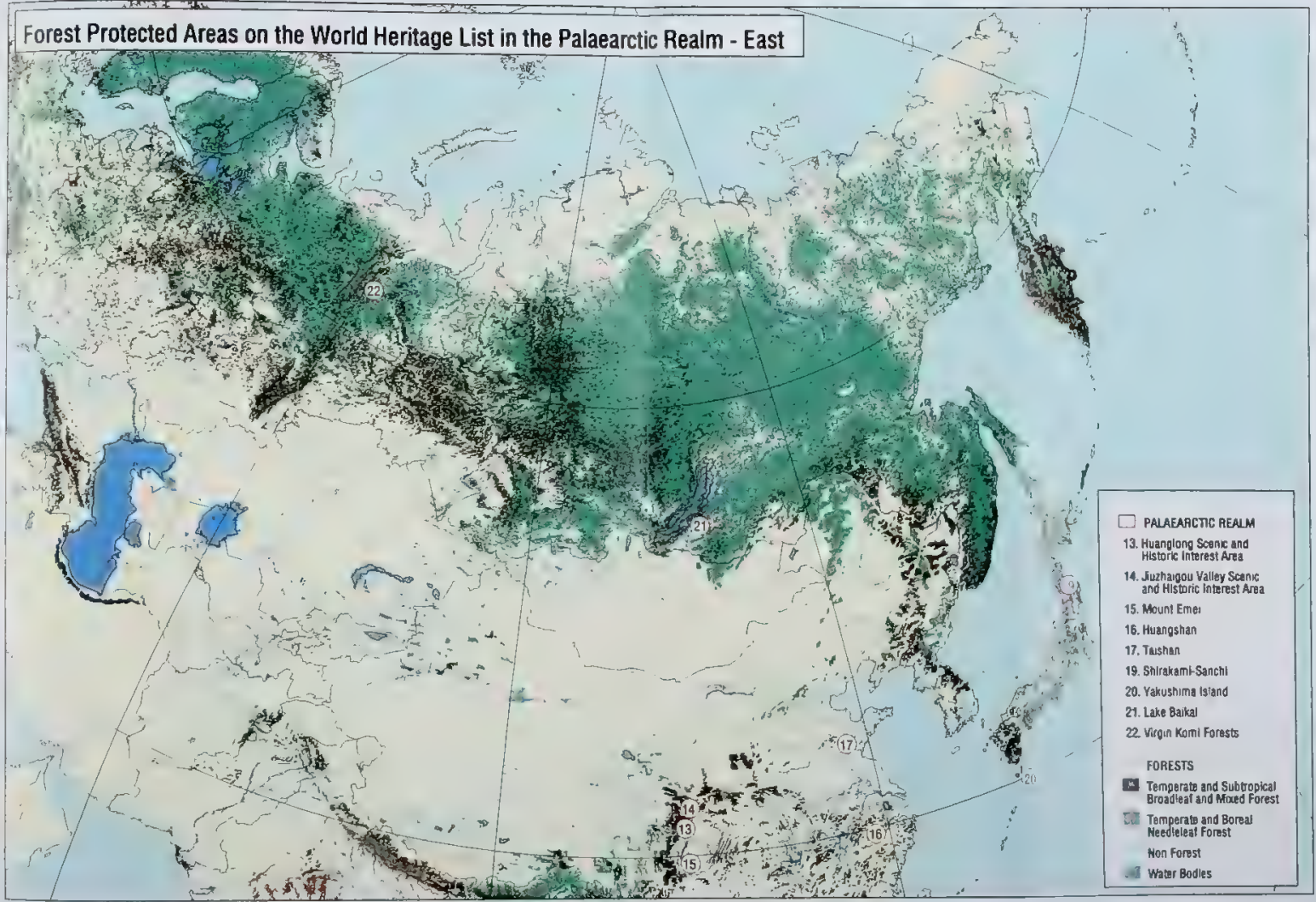




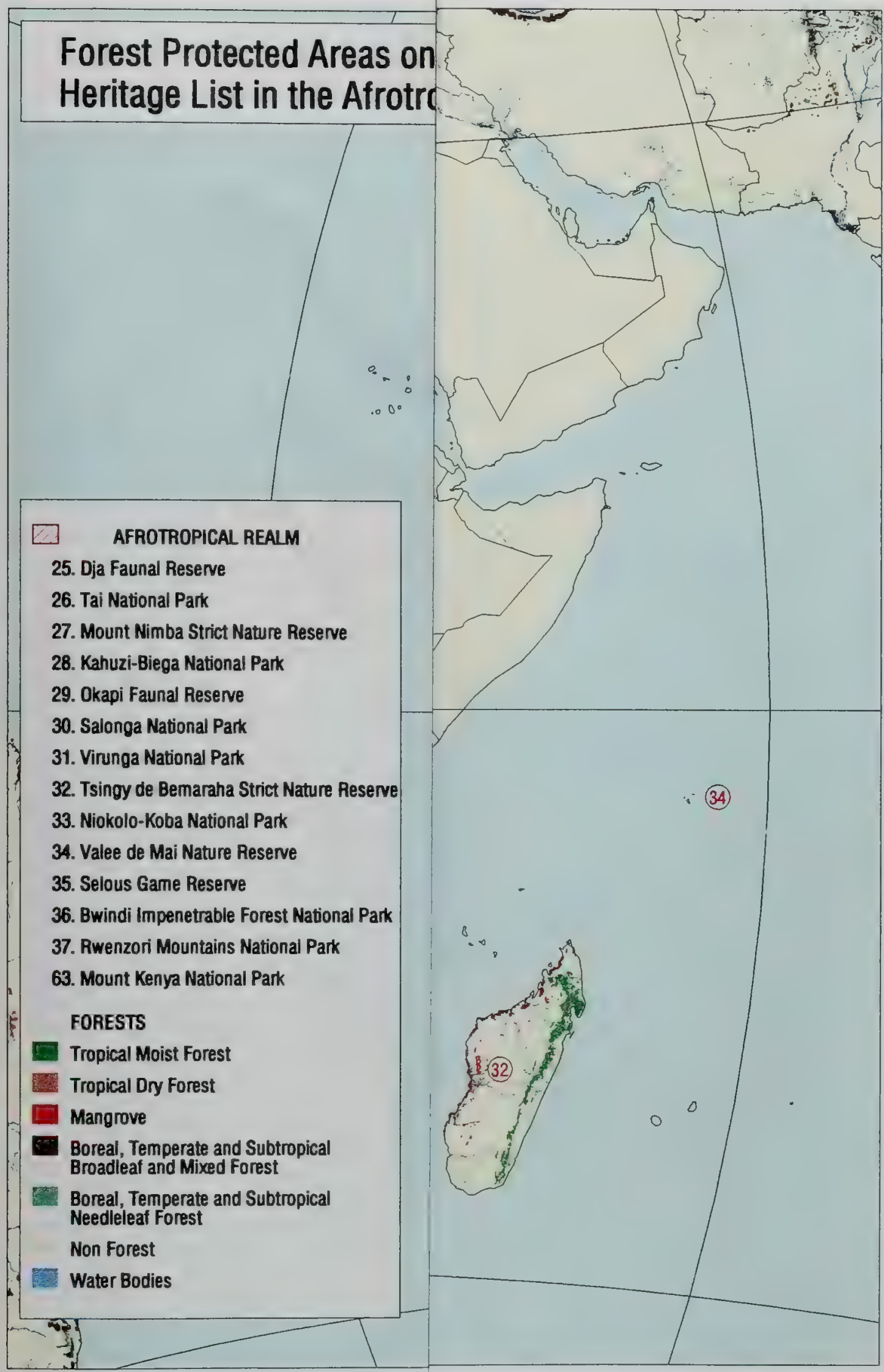




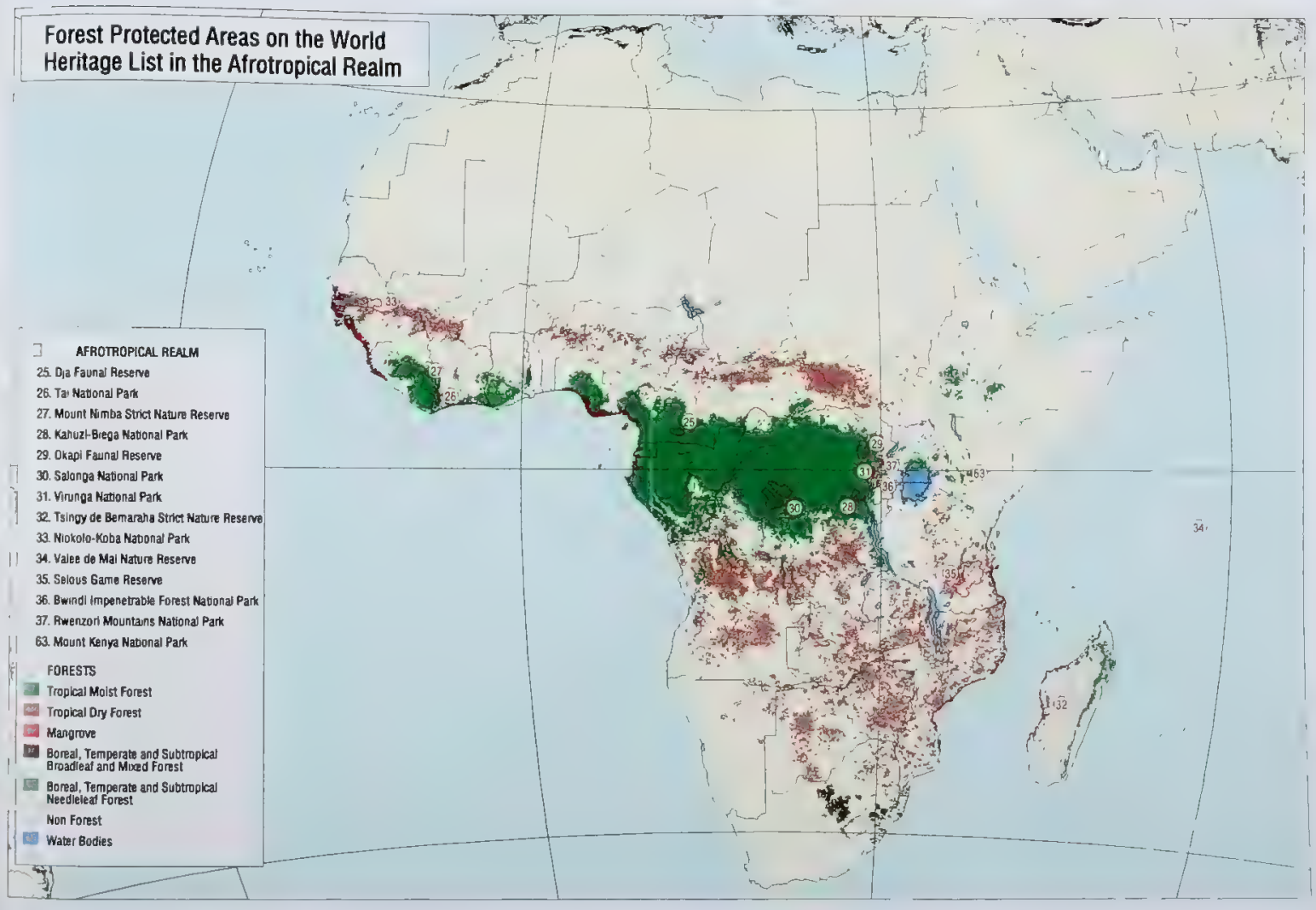




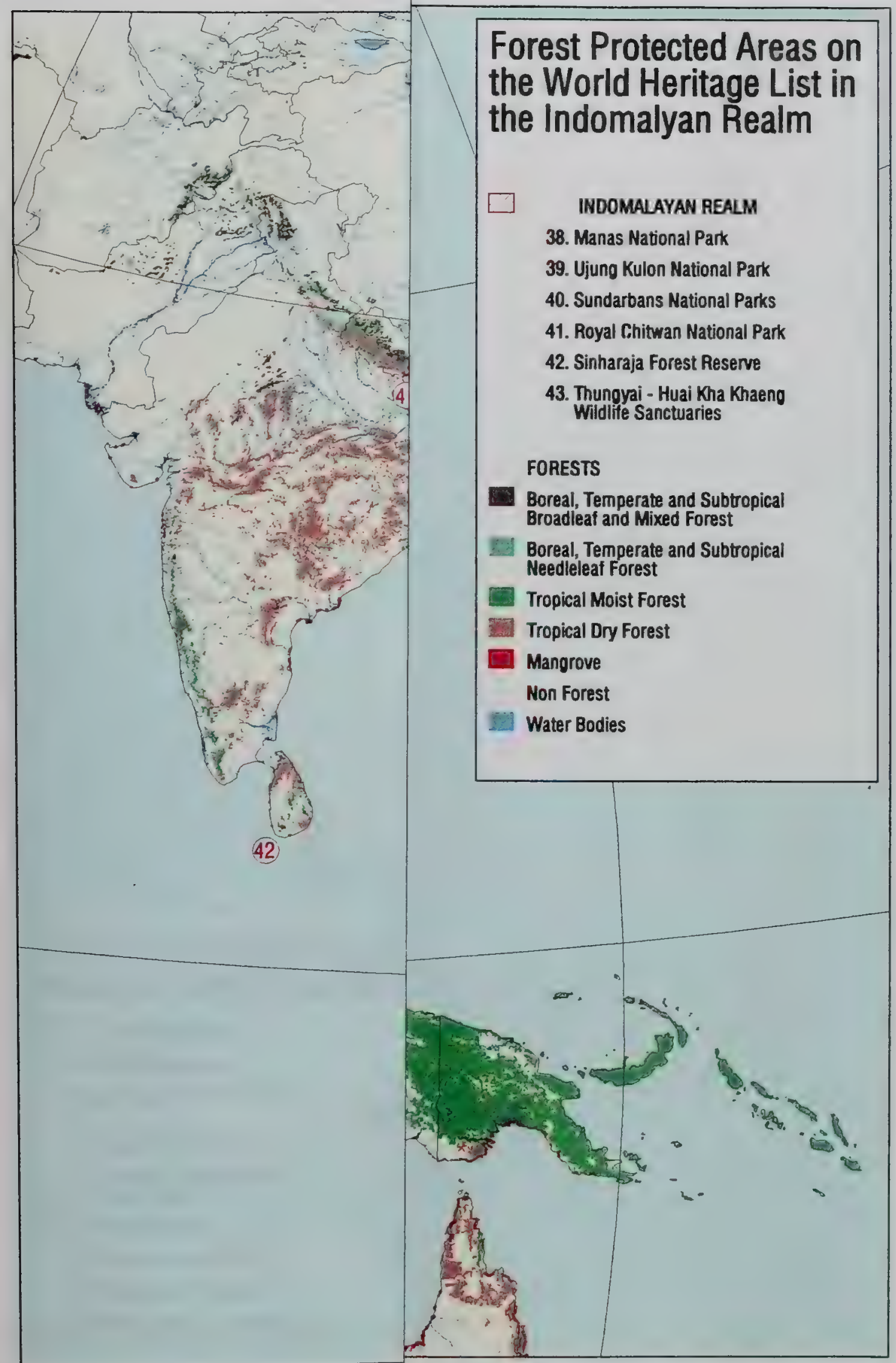




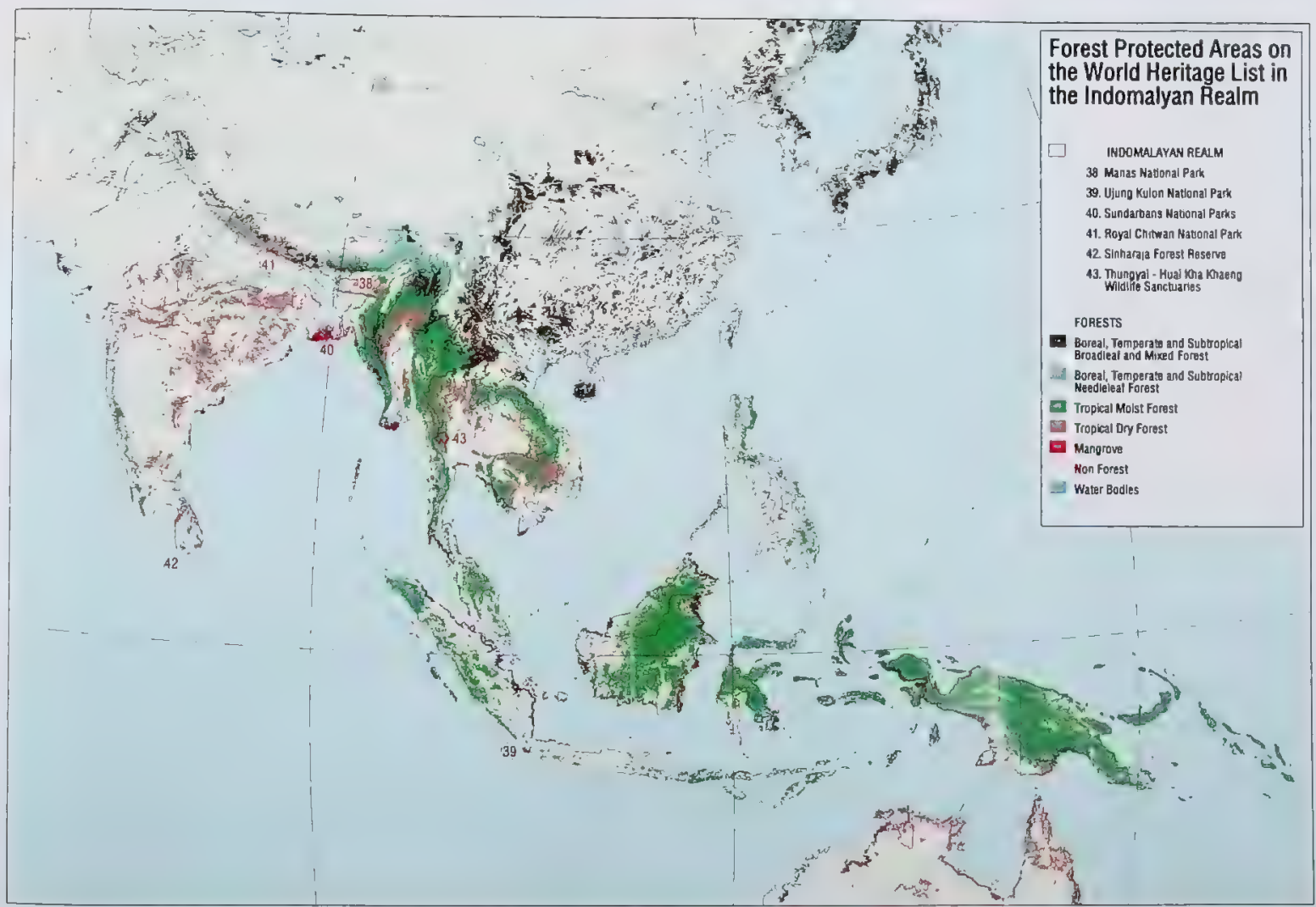




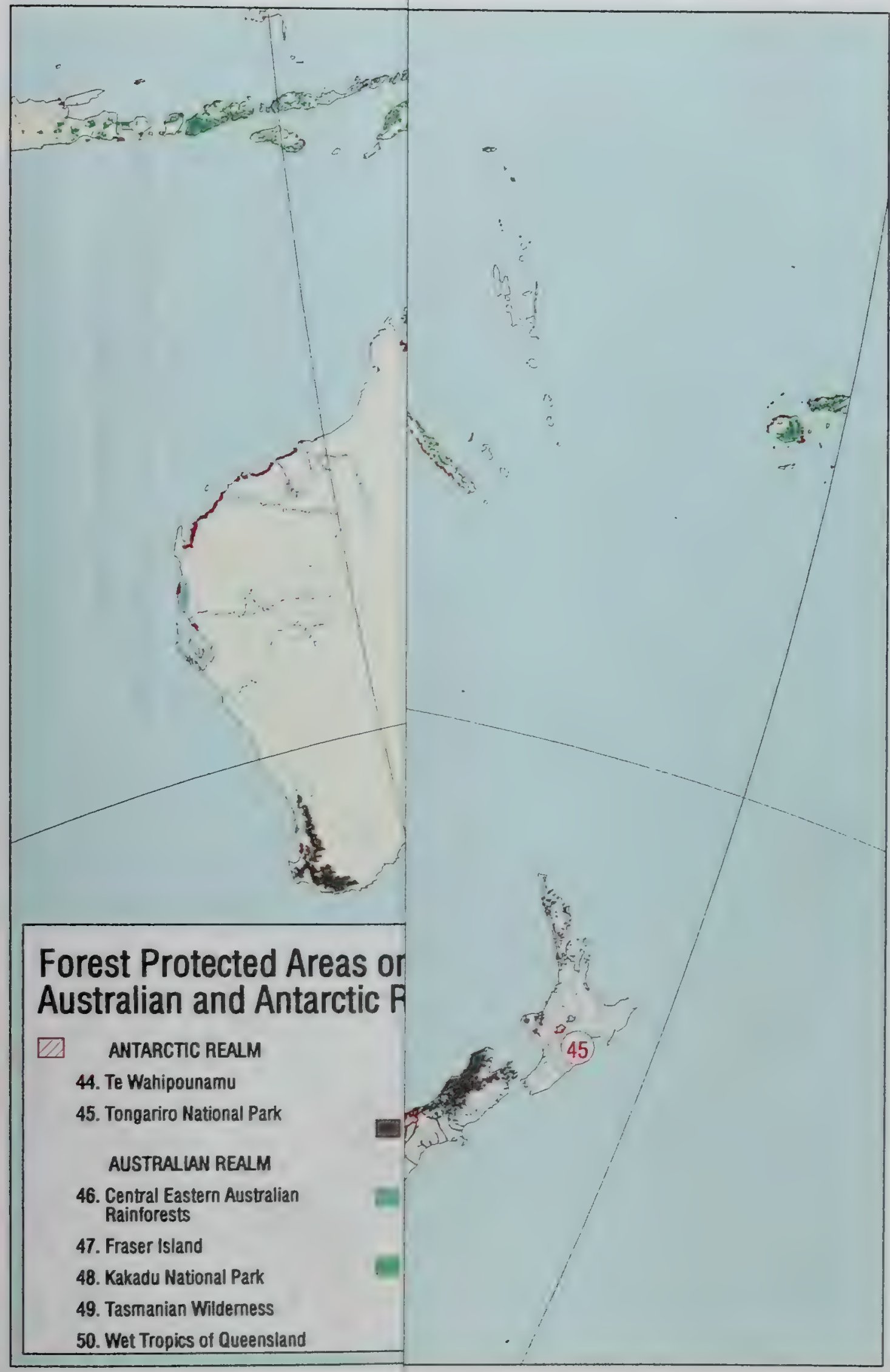




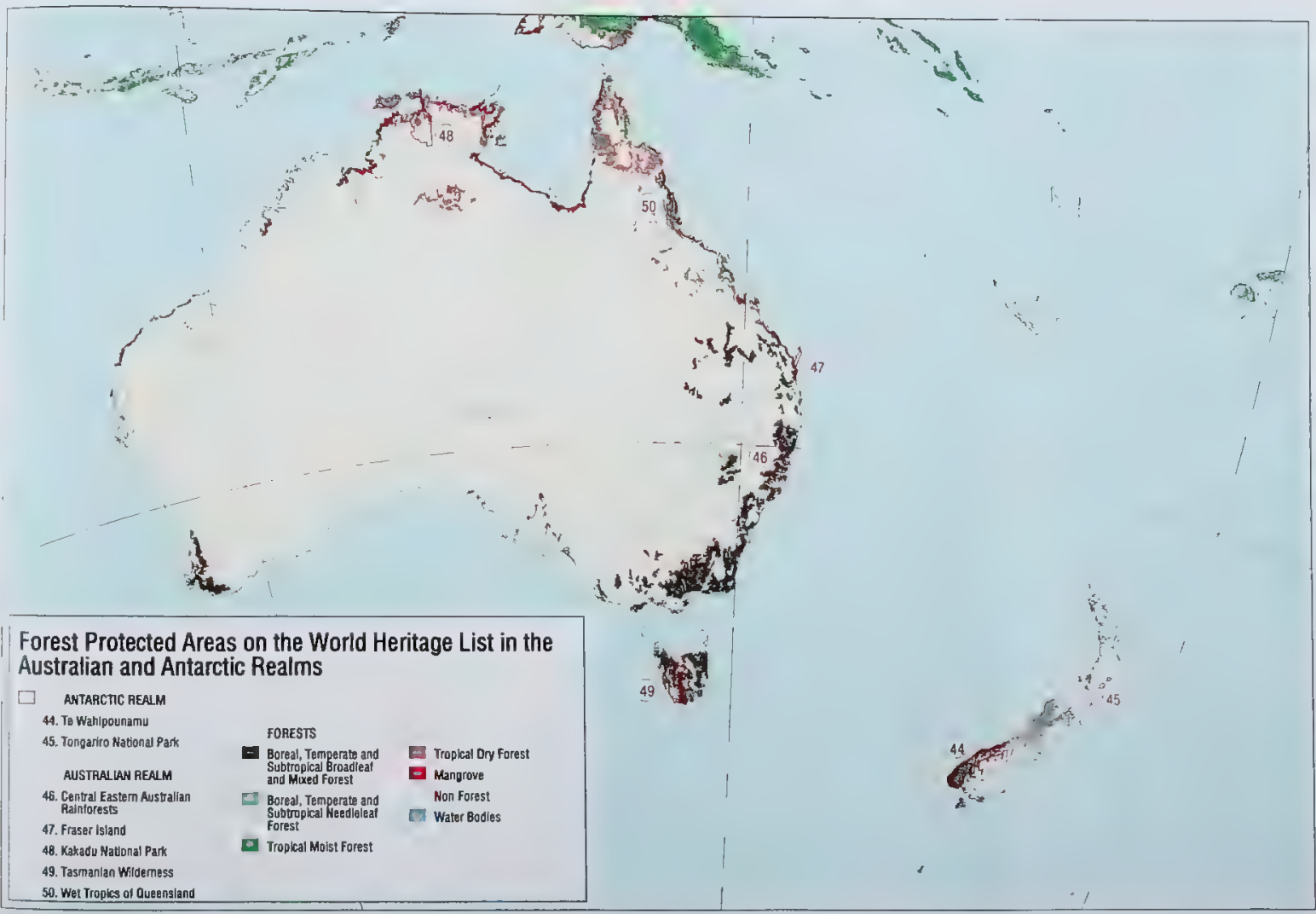




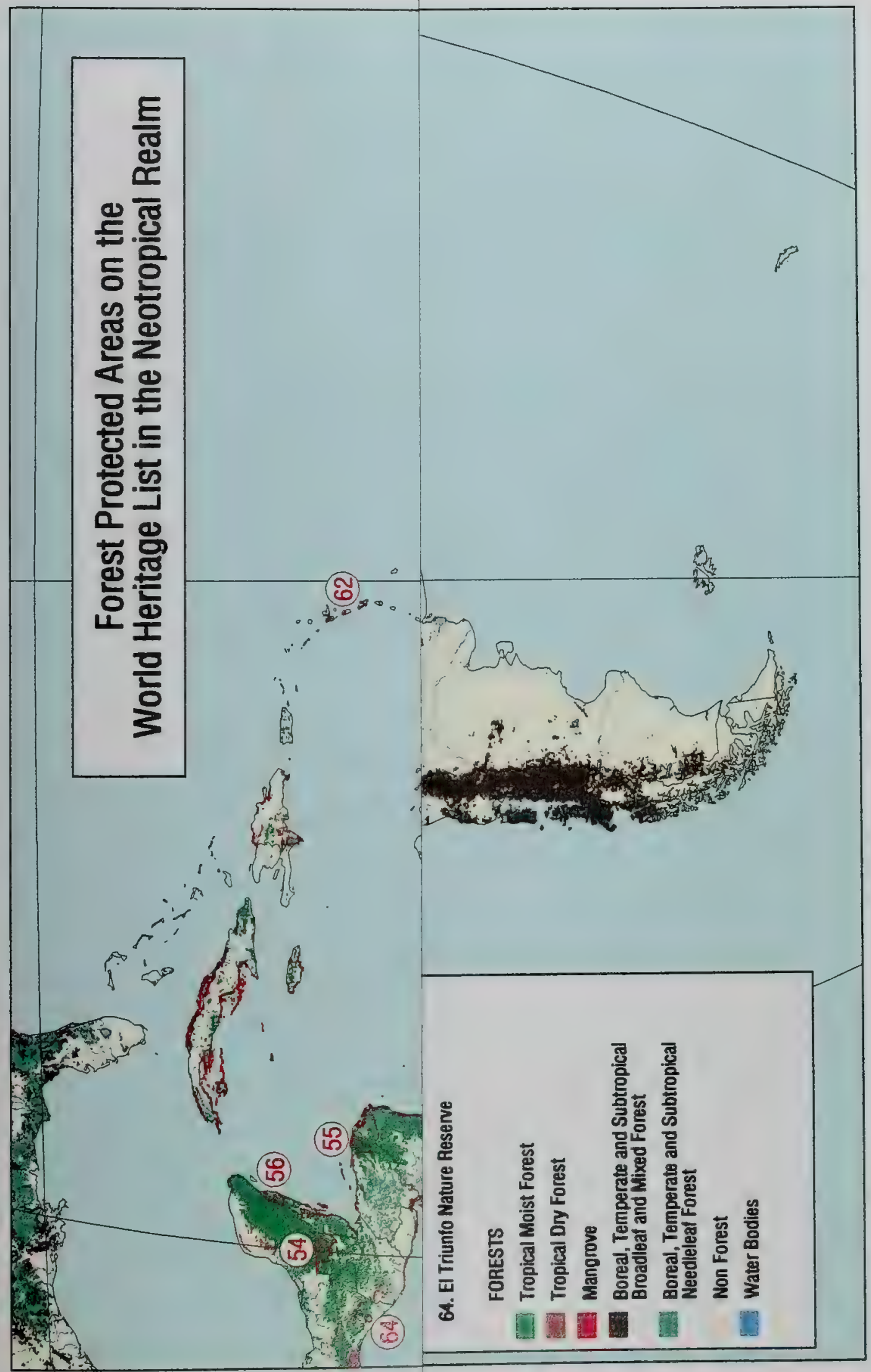




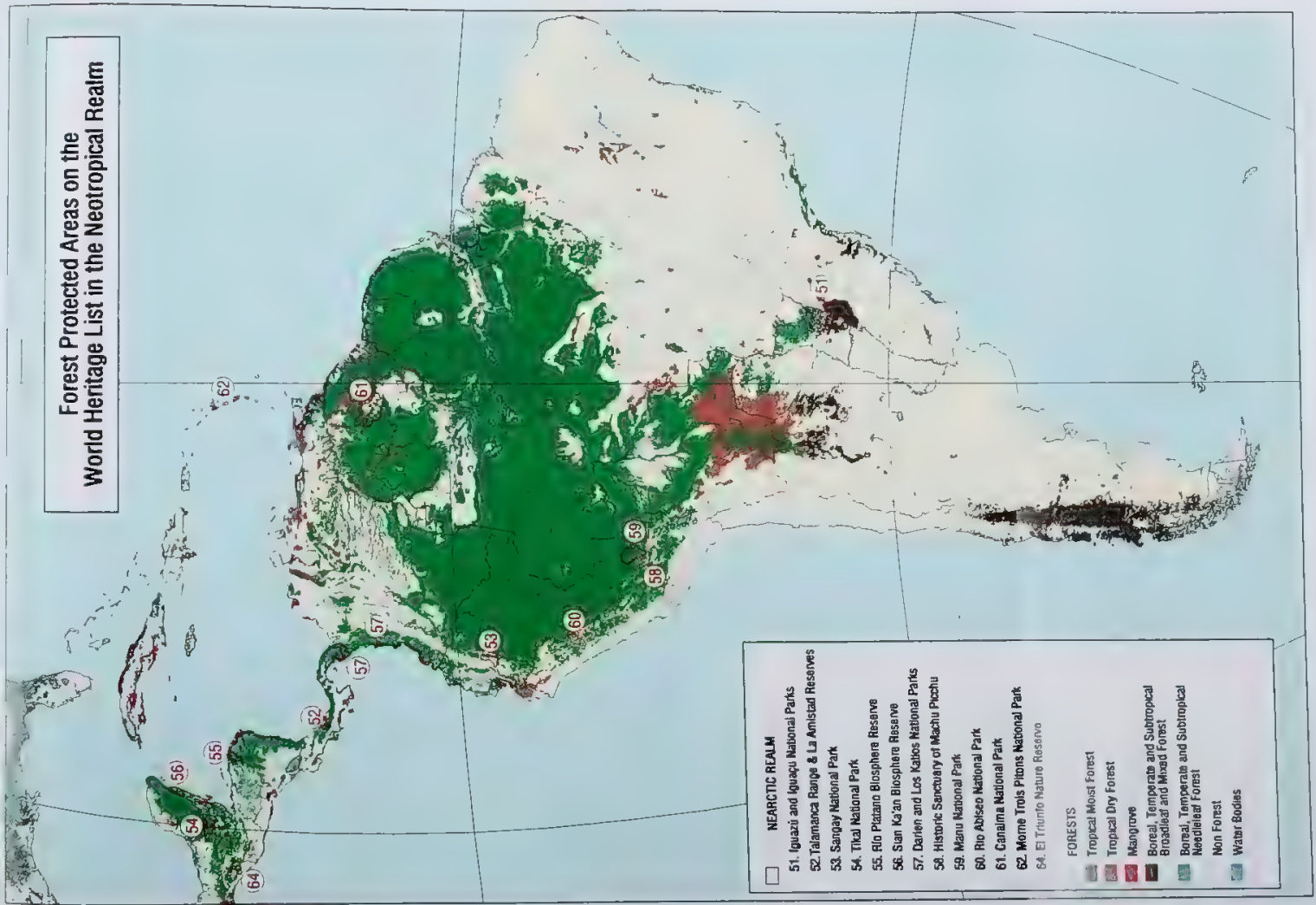




\section{ANNEX}

\section{SITE INVENTORY DESCRIPTIONS}

The following annex inventories the forest protected areas on the World Heritage List ( 61 sites). A key/legend is located at the top of each inventory describing other relevant international environmental treaties and designations. The year each site was inscribed as a World Heritage site $(\mathrm{WH})$ along with the criteria (natural heritage criteria i- iv) for which the selection was based is included. Criteria for World Heritage sites is defined into four categories which are described in detail in the Operational Guidelines for the Implementation of the World Heritage Convention \#43-45 (Attached as Annex 2). Special note is made if the site is designated on the World Heritage Site in Danger List (WD) including the year it was placed on the Danger List. Special note is also made for sites designated as a UNESCO Man and Biosphere Reserve (BR); and/or included in World Wildlife Fund for Nature's (MWF) Global 200 Ecoregions: The Living Planet Campaign (WWF Ecoregion \#). WWF Global 200 Ecoregions (1995) is a broader and more recent overview of global biodiversity than the Udvardy system (1975). The WWF Ecoregions attempt to identify the areas which best indicate global biodiversity that deserve conservation attention. It is helpful to compare these ecoregions with forest protected areas on the World Heritage List and to locate regions with minimal World Heritage protection (gap areas) at the present, in order to establish a list of forest areas which may merit consideration for future World Heritage nomination (Table 8). Of the 61 World Heritage sites included in this overview, 45 are located within a WWF Global 200 Ecoregion.

In the inventory text, World Heritage forest sites are listed in rows and categorised by Biogeographic Realm (Udvardy, 1975), which divides the world into eight realms: Nearctic, Palearctic, Afrotropical, Indomalayan, Oceanian, Australian, Antarctic, and Neotropical. In the inventory text, the columns include the country name, the World Heritage site name, and the physical area of the World Heritage site in hectares (may differ from the size of the national park or other international designation) as stated in each site's nomination. The final row explains the major characteristics of the forest protected area within the World Heritage site. IUCN welcomes comments regarding the forest protected areas in any of the sites included in this overview, which will be useful in preparation of future revisions of this working paper. Attached are the World Heritage Operational Guidelines \#43-45 which cover the criteria for inscription of natural sites on the World Heritage List (Annex 2). 



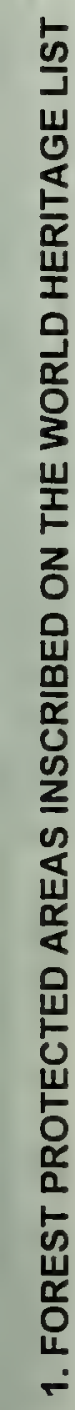

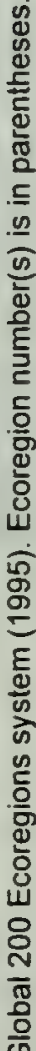

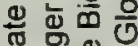

은 흔항

옹동

蛋 $\sum^{\pi}$

훙요

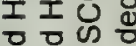

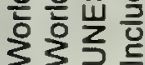

恣

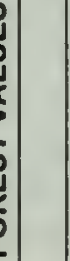

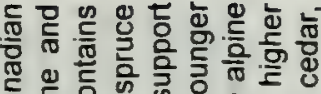

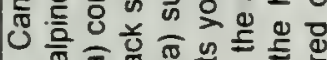

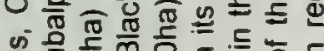



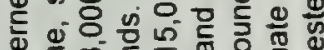

क्ष

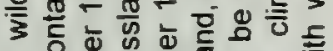

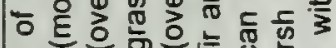

응

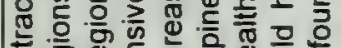

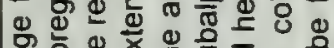

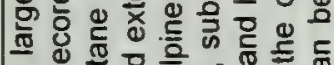

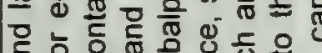

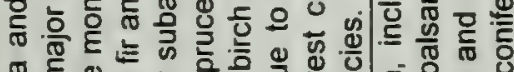

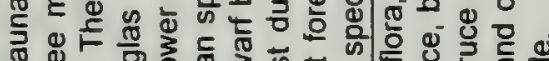

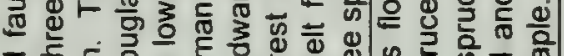

少

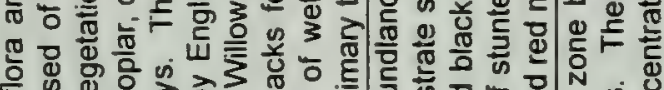

พ⿺辶

는 $>$ a

ฆ

ऐ

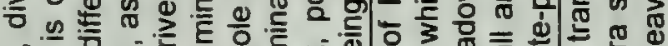

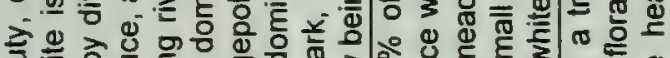

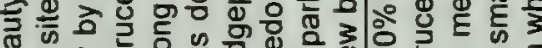

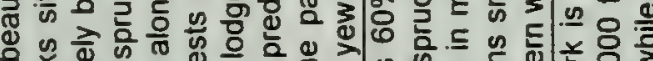

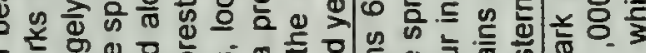

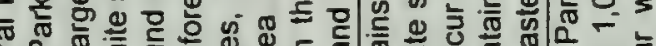

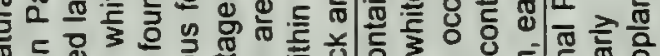
둥

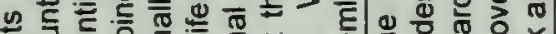

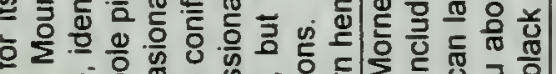

范

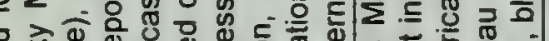

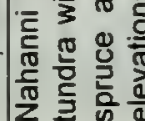

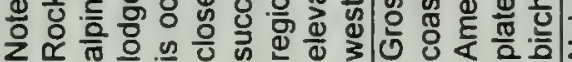

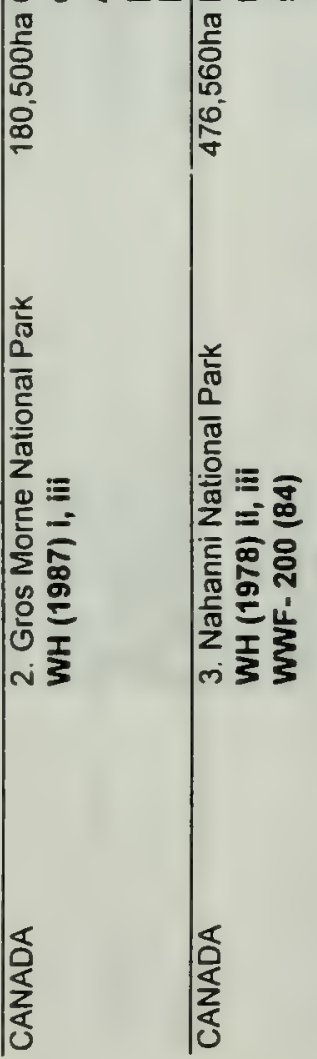

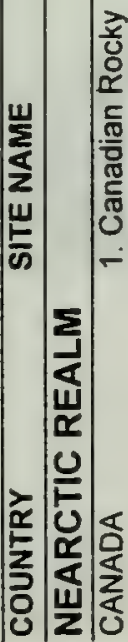

공

$\overbrace{0:=}$

든

范 :

$\frac{1}{2} \frac{T}{3}$

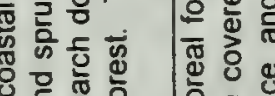

का 응

总

艎

튼

然


ஸ

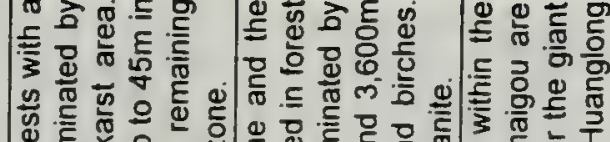
응 등 옥

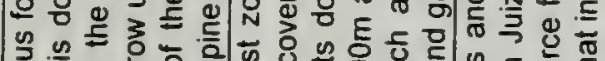

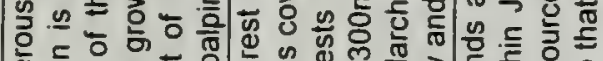

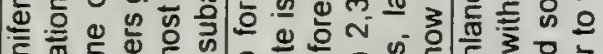

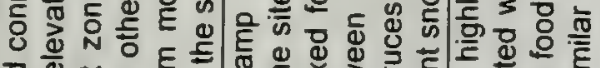

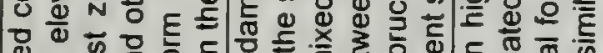
ख્山 ह 츨 들 을 E 万人

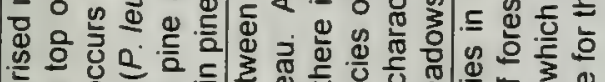
을

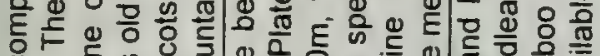

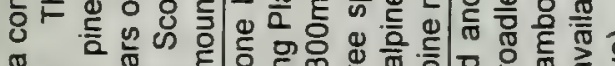

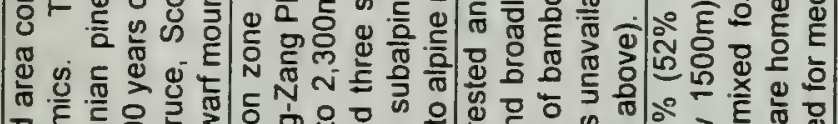

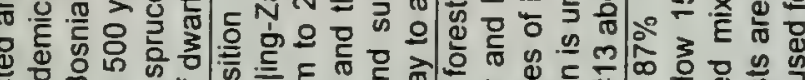
过 융 은 등 है 光㐘 ธ щ

일 응 들 웅

คำ

जे ते

i⿵ $\frac{0}{1}$ 宁

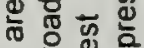

옹 은

屯ั

은 음 응 엉

ब

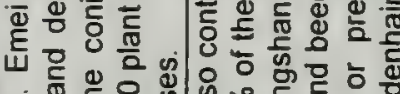

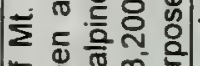

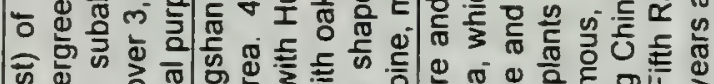
嵌

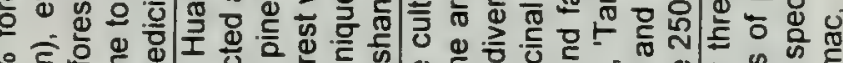

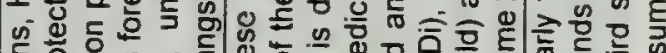

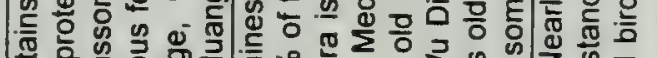
군

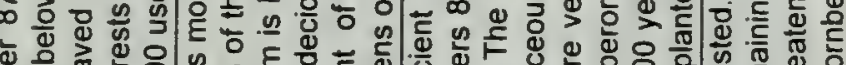

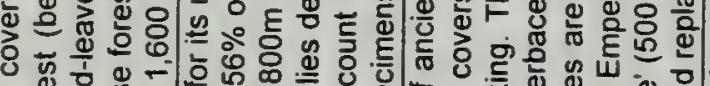
ญ

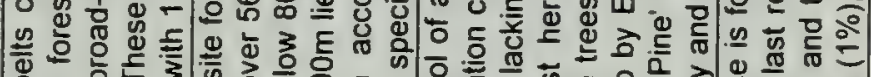
율

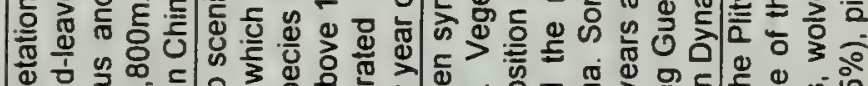

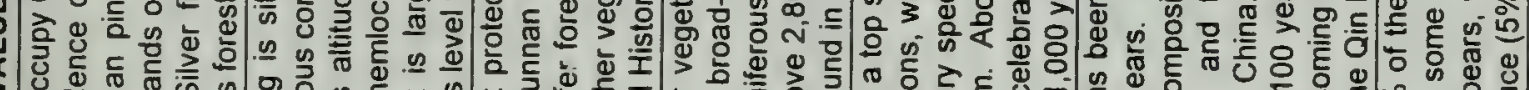

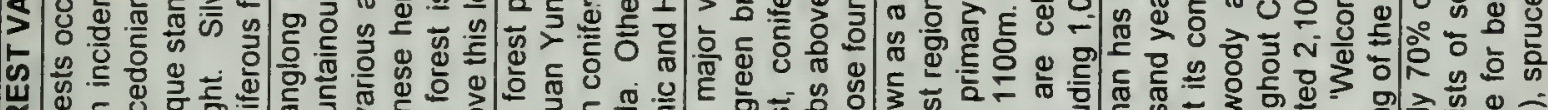

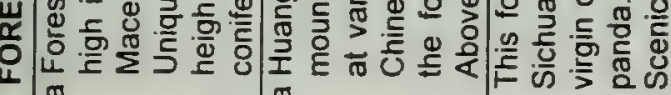

$\frac{\mathbb{w}}{\frac{w}{\alpha}}$

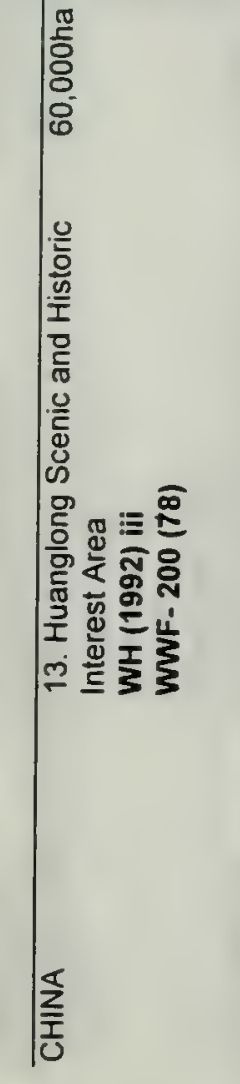

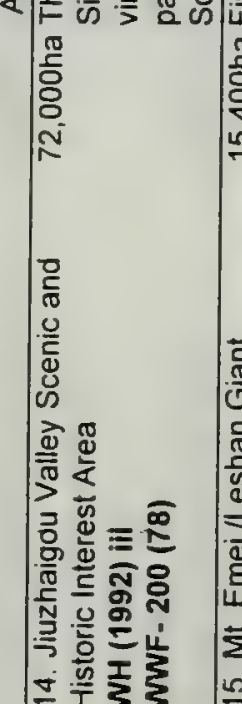

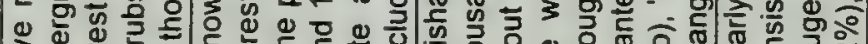

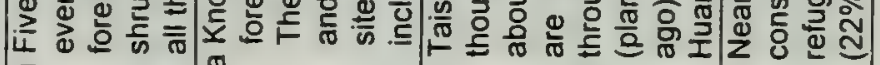
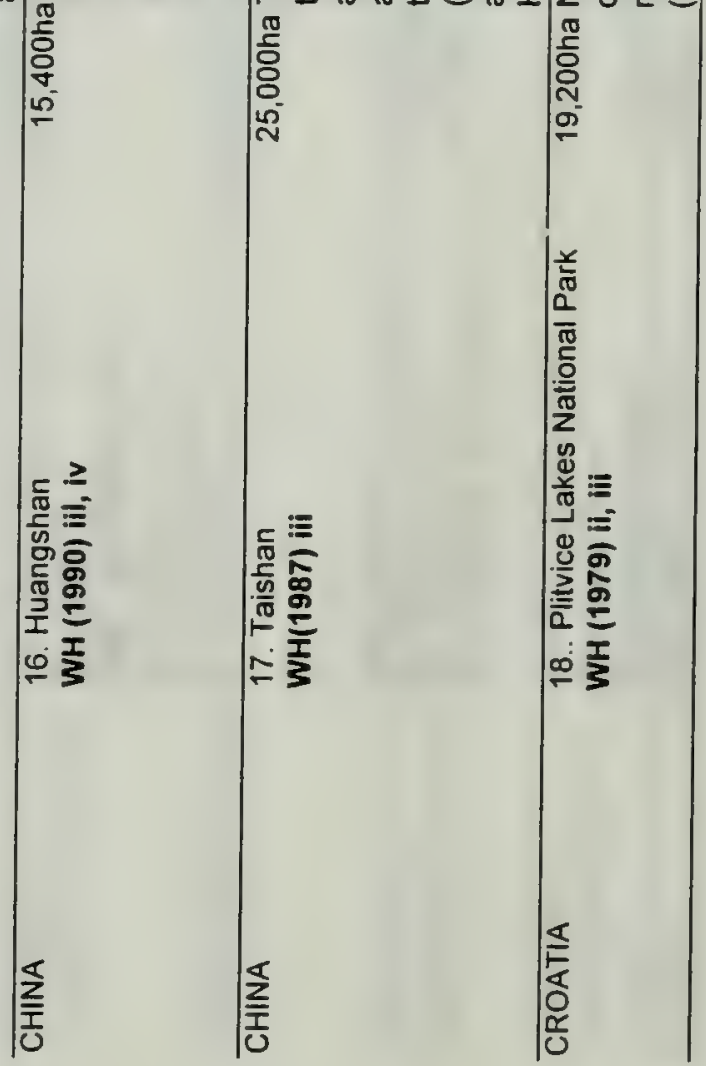


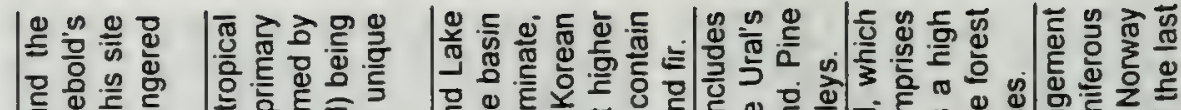

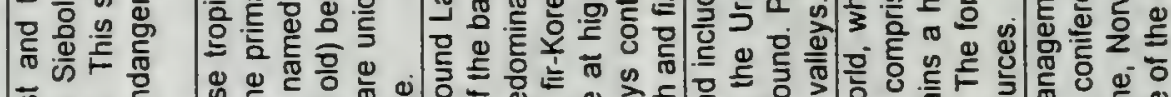

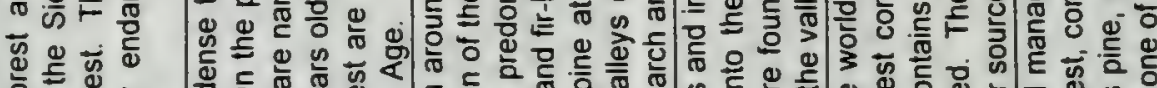

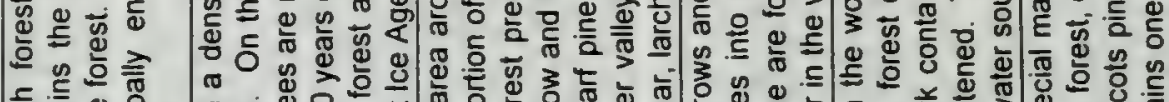
ร 泮 。

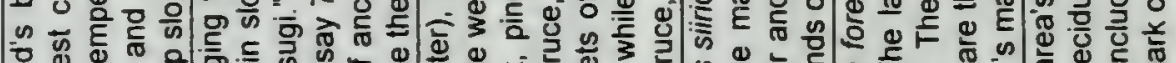

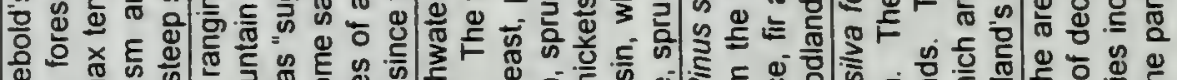

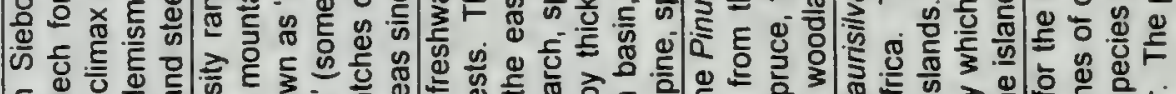
듷용워

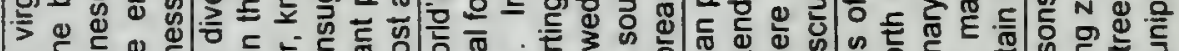
屯头 范 ஐ

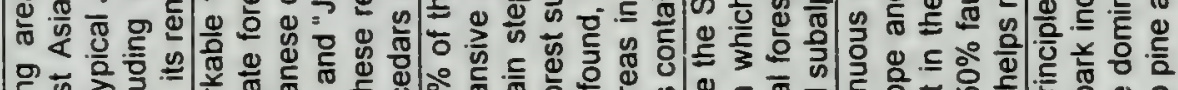

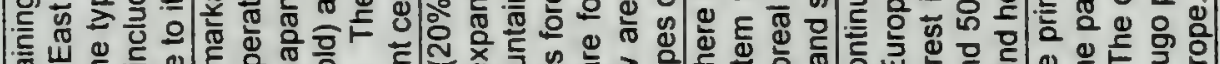

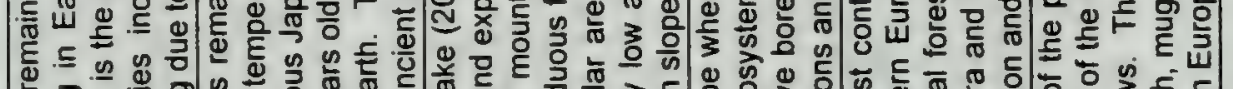

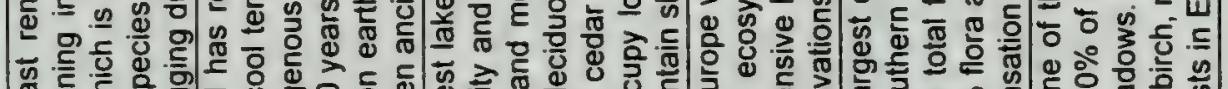
雨

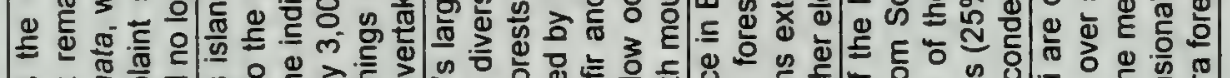
n 产

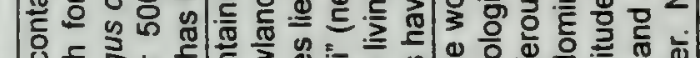

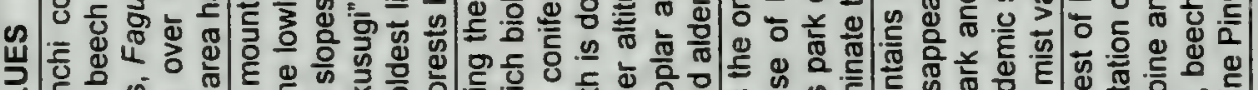
\市

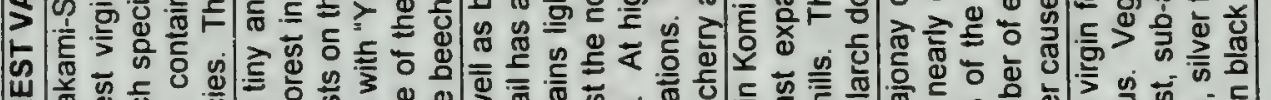

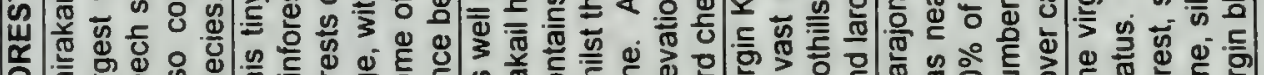

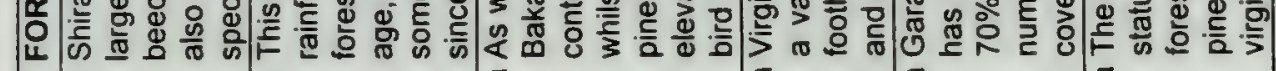

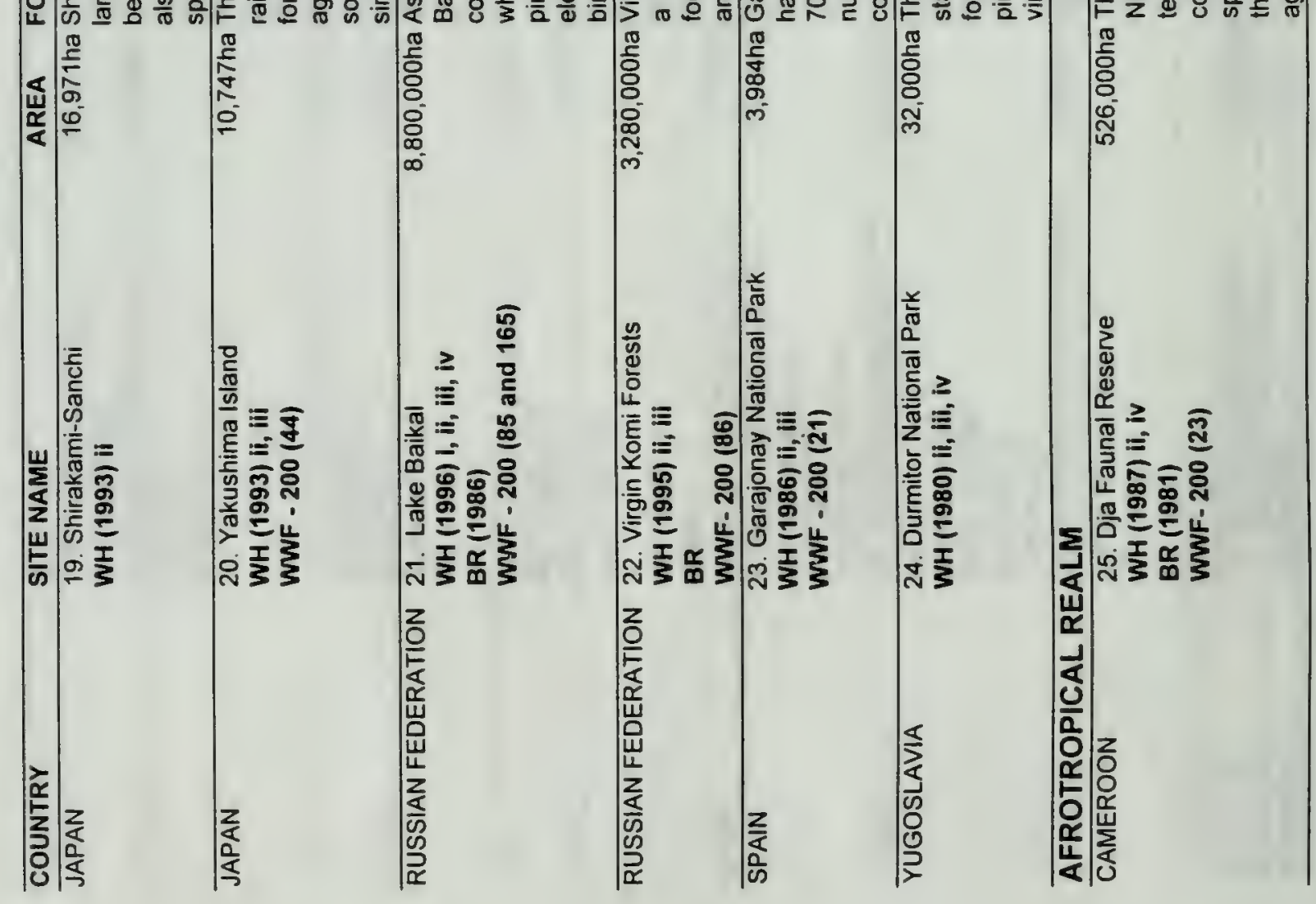




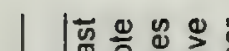
뜽 इ के है

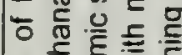
凹ण ए 긍 용 은 중 든 눈은 엉 ㅎํ을 《ठ ठ ठ 을 क्ष

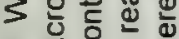
ᄃ Ш 응 흔

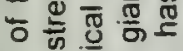
을 ⿺辶응 흔

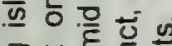
들 올 을 的包至产 ఫ叫 ๘ँ 改 엉 离 느 है

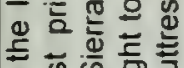

แ

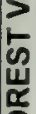

焉 <

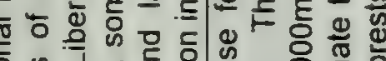

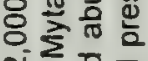
그 $\frac{\mathrm{C}}{\mathrm{C}}$ ว 들 흐은 उ 뜽 음 $\stackrel{\bar{\sigma}}{\overline{1}}$ 은 든 는 홍응 은 든 응 可 등 옥 흘 ช

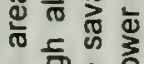

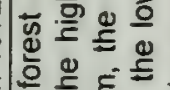

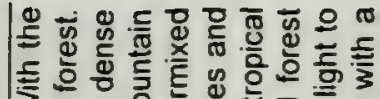

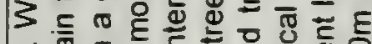

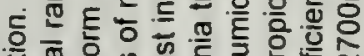
은 즌 으웡

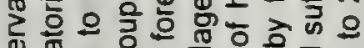

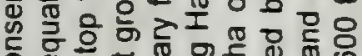
ᄃ어유 U

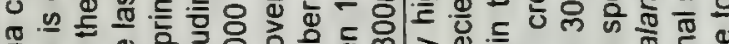

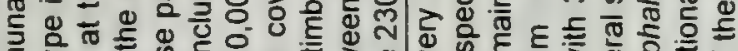
刃ำ

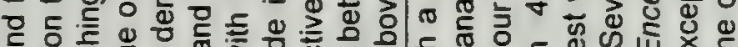

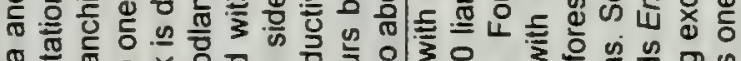
ता

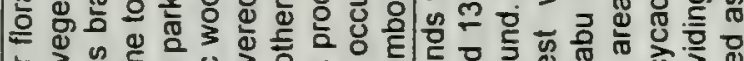
ち월 ه

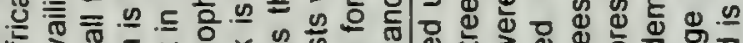

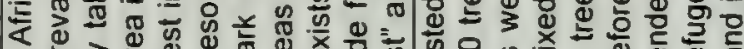

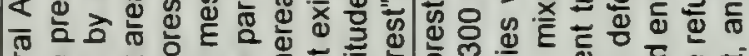

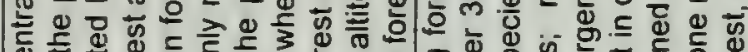
Uू స 들 들 है

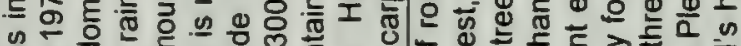

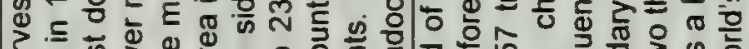

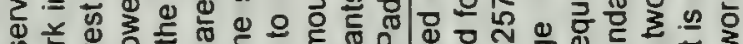

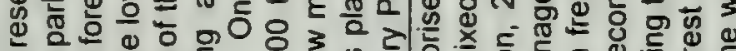
के 怘

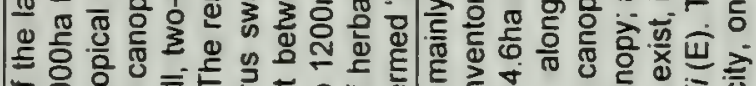

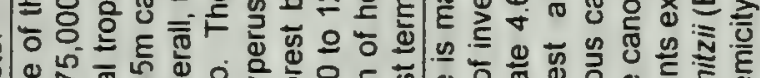

芯芯紊 क

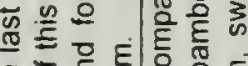
Ð ज市的氙 읃은 कर 응 을 응 岳 क ठ 凹 든

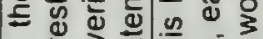
든

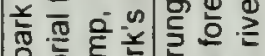

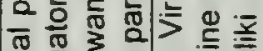
음 क त ธั ఏ 는 我

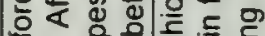
즐 들

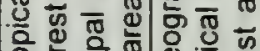
응 는 은 흔 क 뜬 흥 은 는 으 क्ष

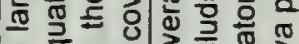

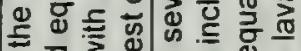

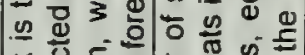
넌 은

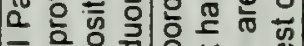
ॠ

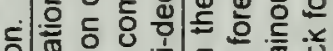
语 월 월 今)

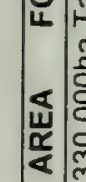

$\sqrt{2}$

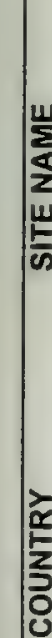

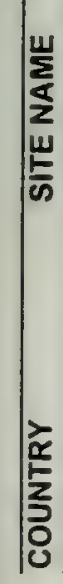

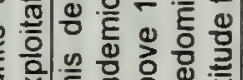

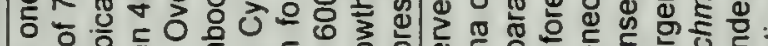
元 ส
(⿻

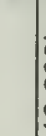

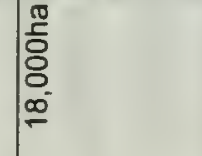

옹

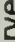

密

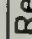

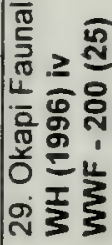

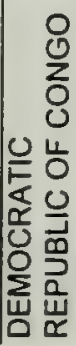

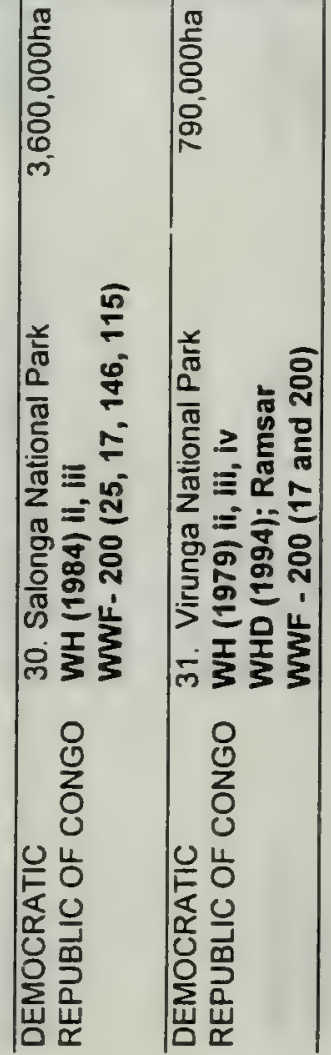




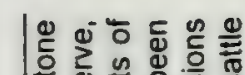
응 웡

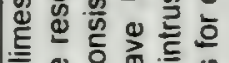
心 두워

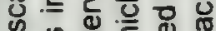

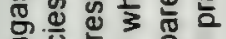
웡 क क 5 更

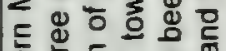
혼

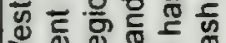
उ क्ष 흔

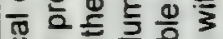
을 可 之象 की क्ष 흔

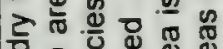

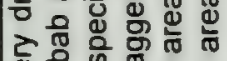
क응 का

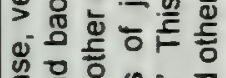

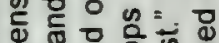

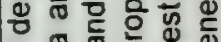

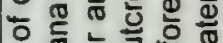
들

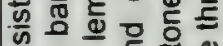

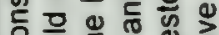
उ इ के है

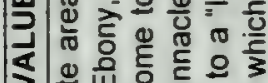

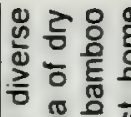
등 원 ํํㅇำ

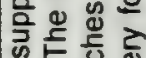
ㅇ.. 西

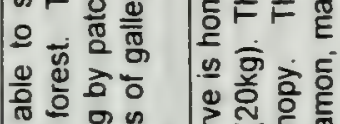
तิ 응 뜨 든 등 岳 त

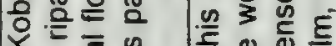
ำ

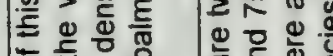

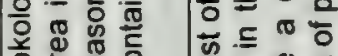

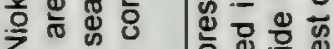

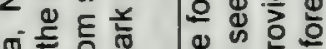

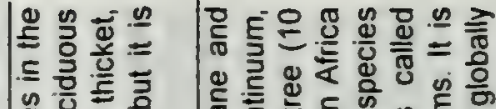
ن으을 㡙 등 흥 으을 을 당요의 응

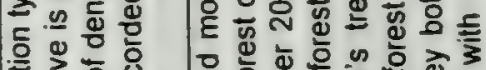
क्ष बैल

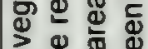
ट

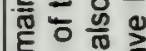
ㅇำ

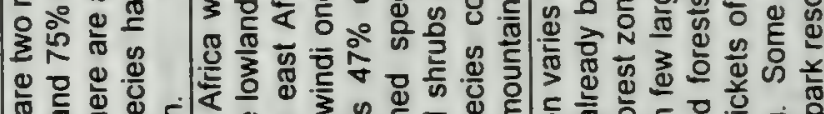

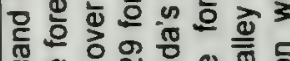

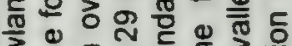

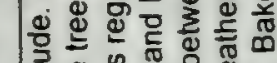

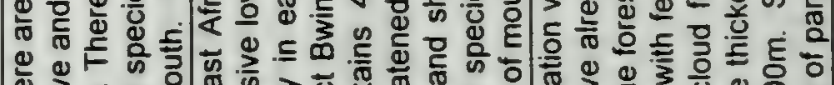

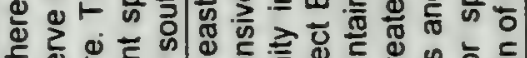

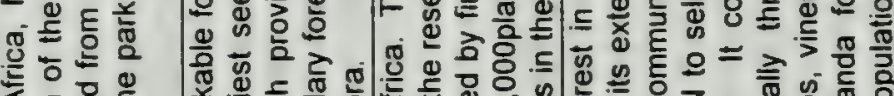

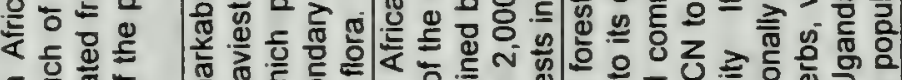

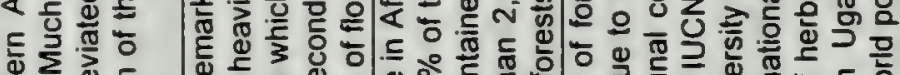
ญ

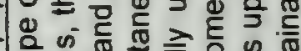
3 늠 ङ 凹 थ 응 음

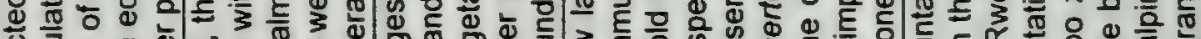
记

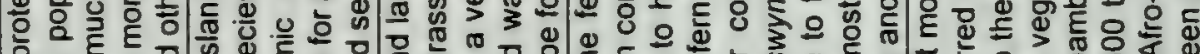

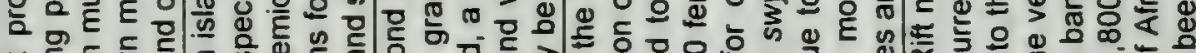

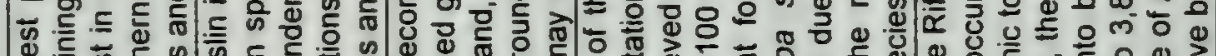

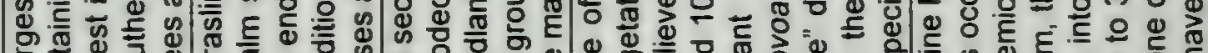
究

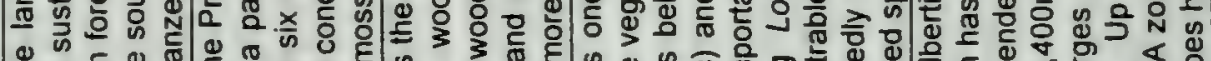

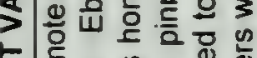
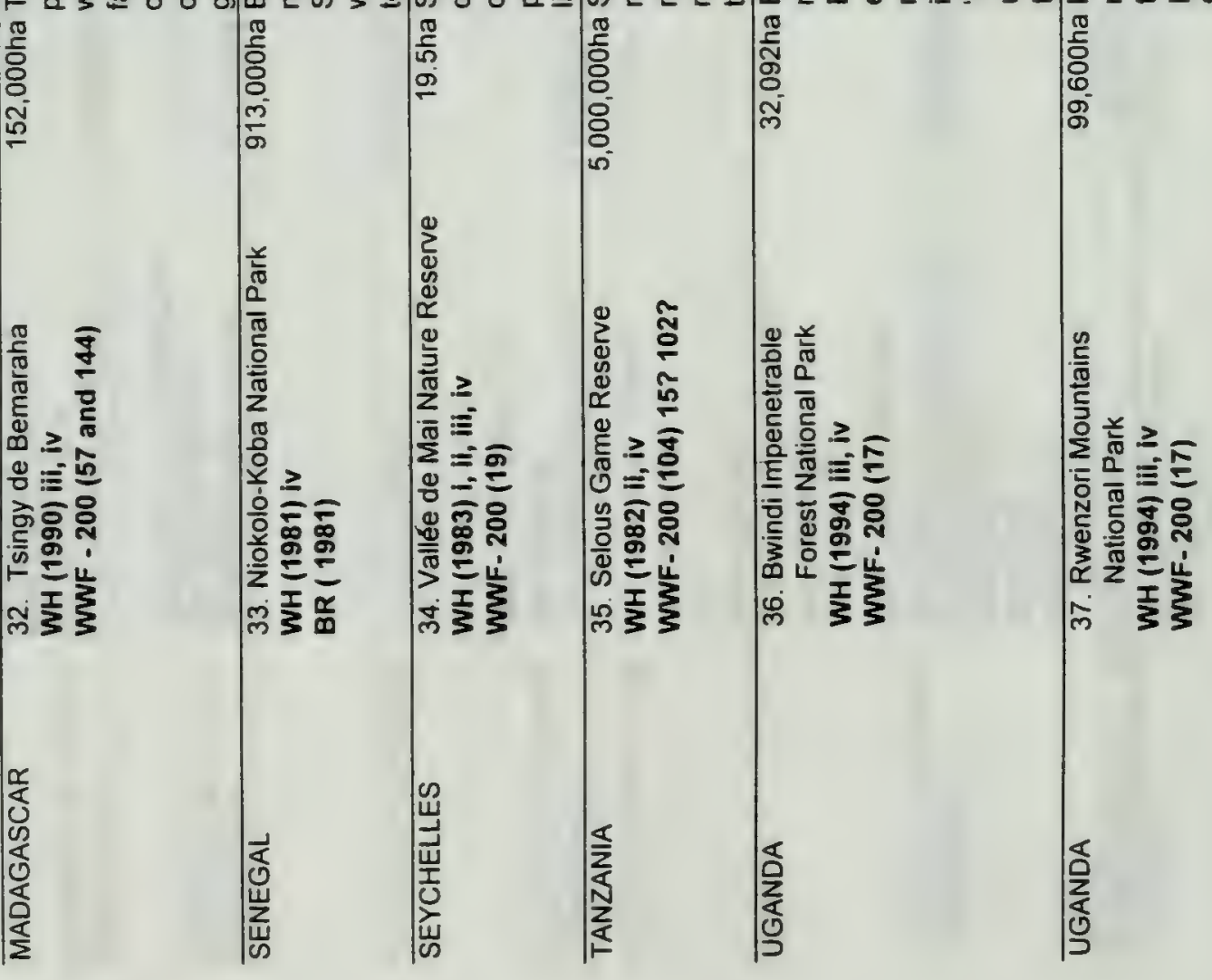


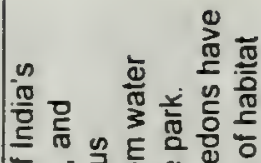
음

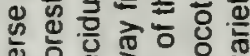

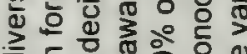
츰 प्ष

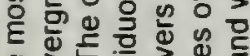
Q >

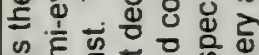

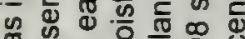
त

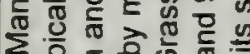
○은 득융 융엉 क्ष ⿻

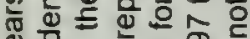
ఖ $5 \times$

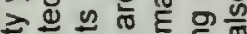

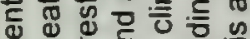

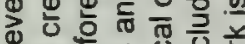

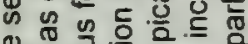

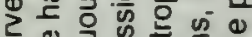

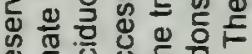
ब象

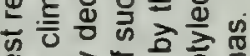

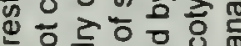

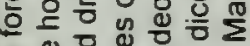

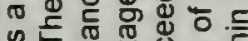

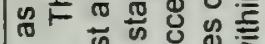

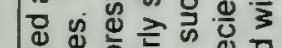

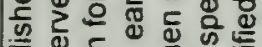

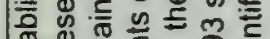

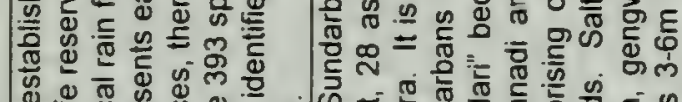

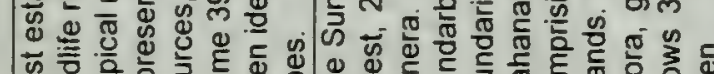

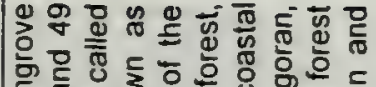

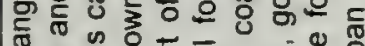

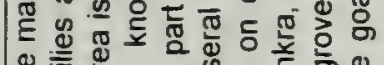

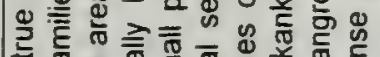

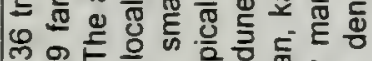

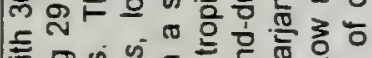

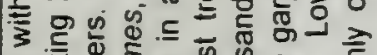
卷 总

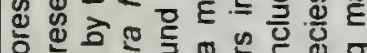

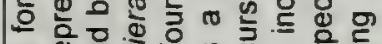

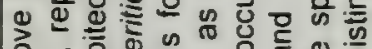

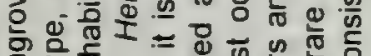

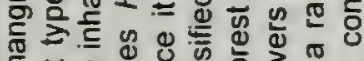
है 흥으은은 둥 ᄃ응 के

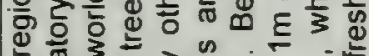
药

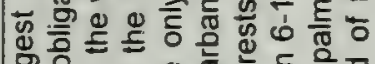

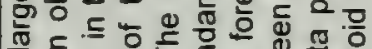
舟

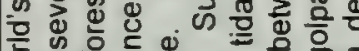

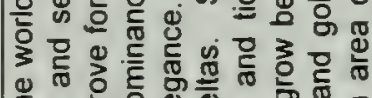

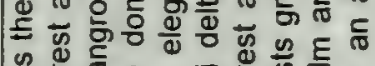

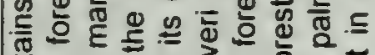

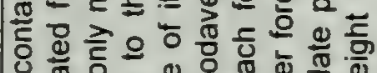

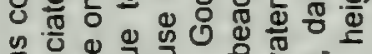

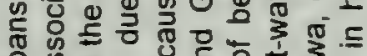

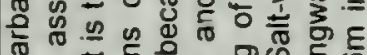

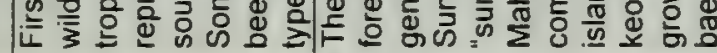

要

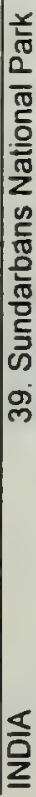
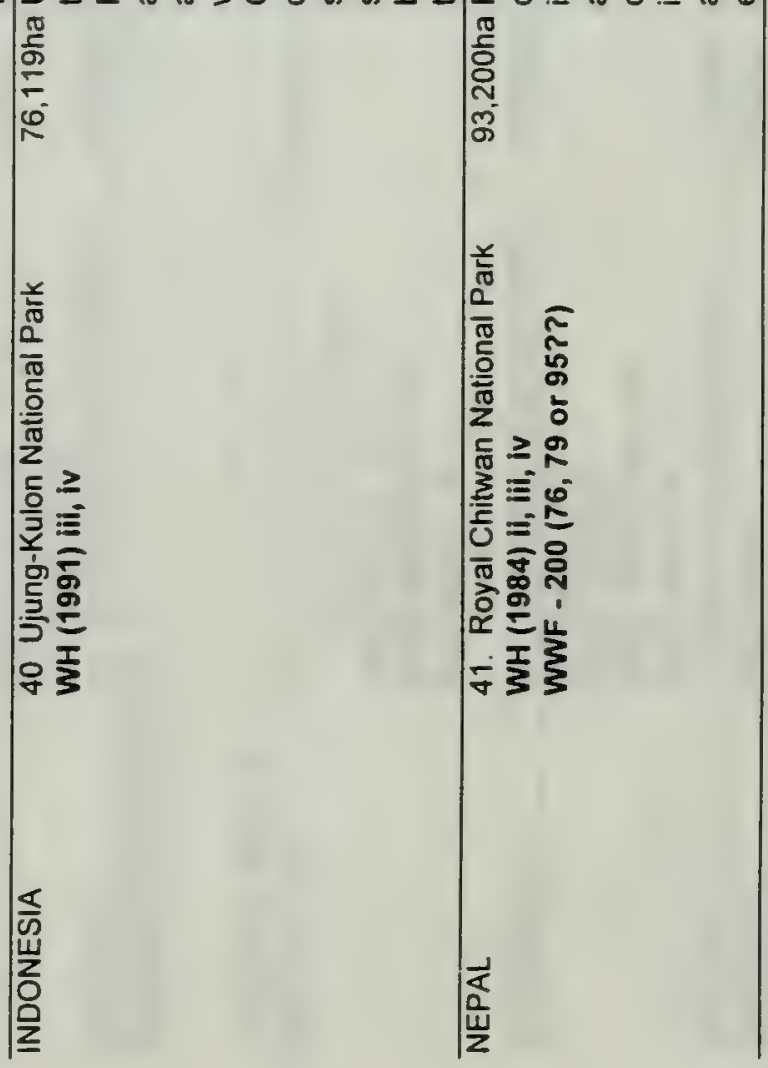

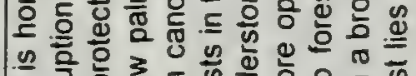

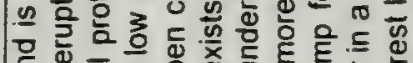
舟

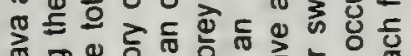

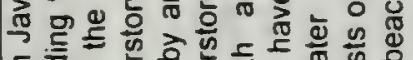
들

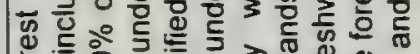
总识

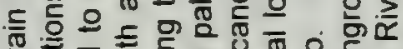
एँ 든

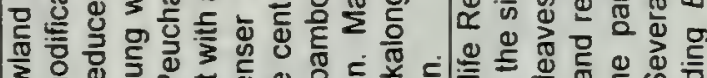

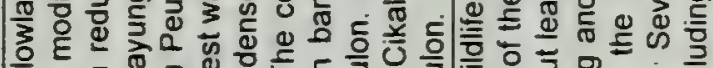

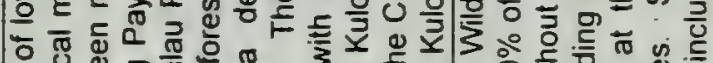
엉

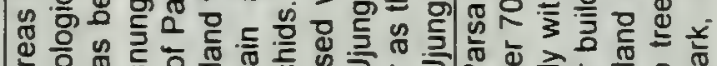

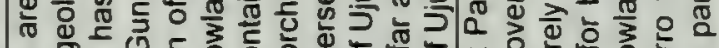

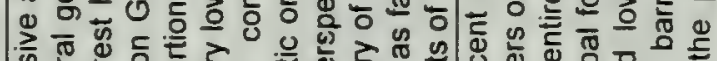

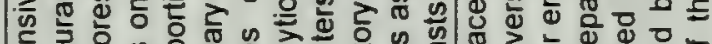

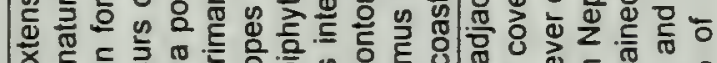
х

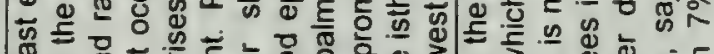

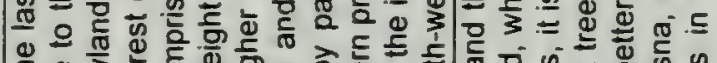

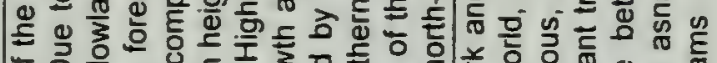

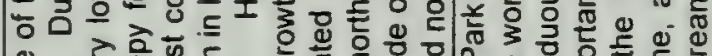

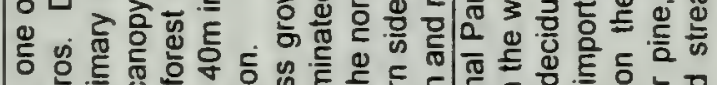

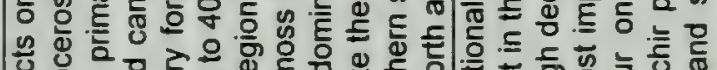

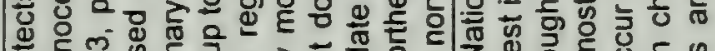
흥돈 ᄃ드음

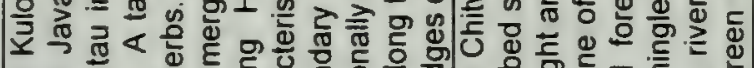

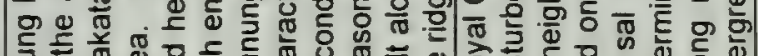

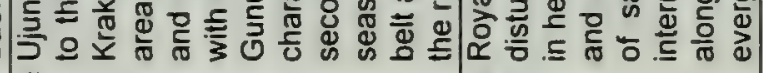




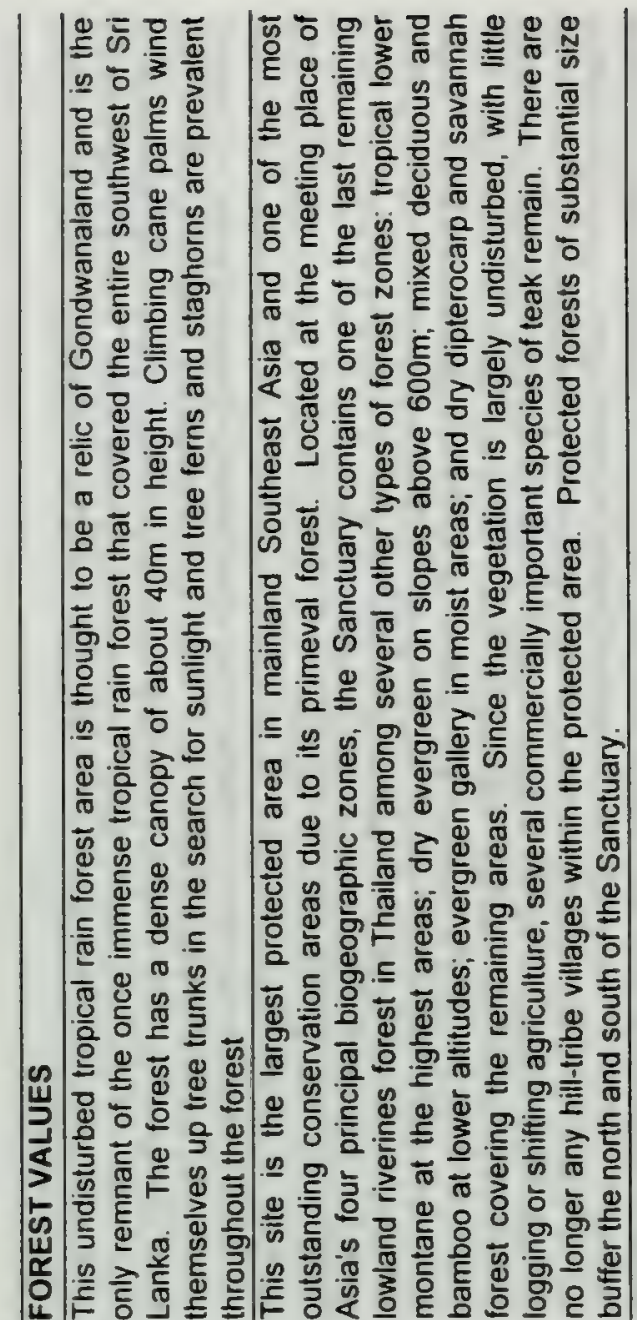

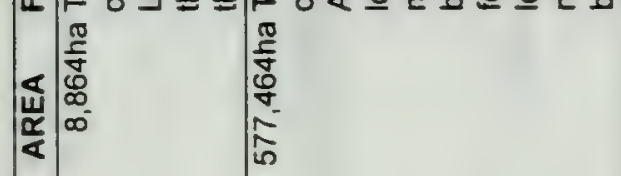

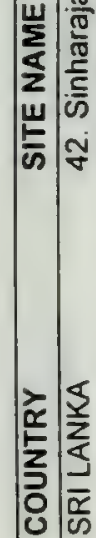

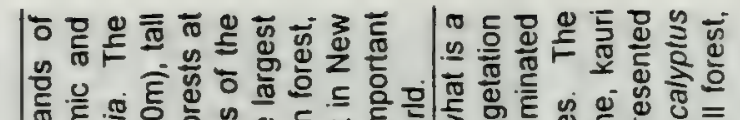

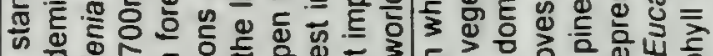

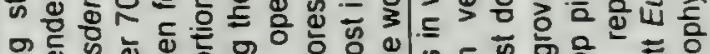
옹

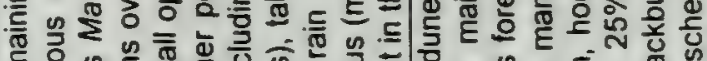

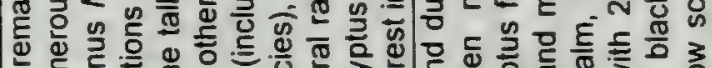

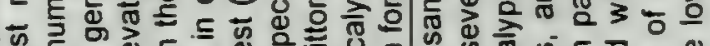
品

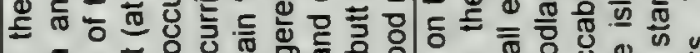
ธ तᄁ

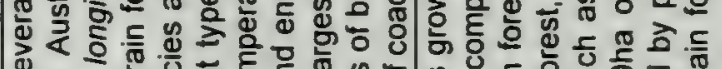
出

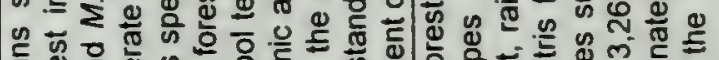

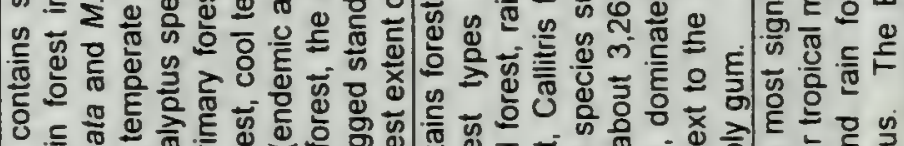

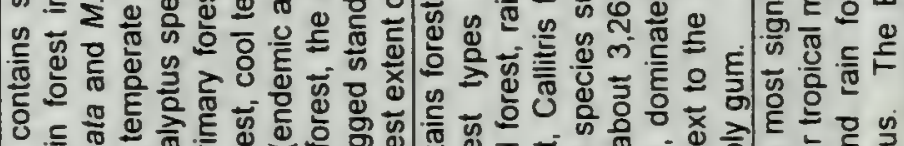
(1)

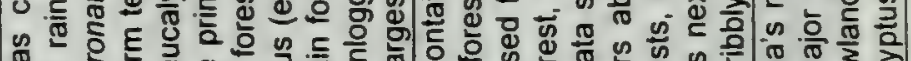
崩

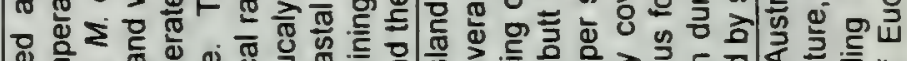

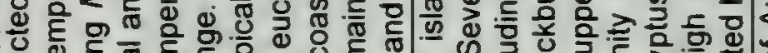

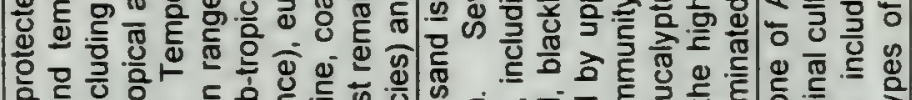

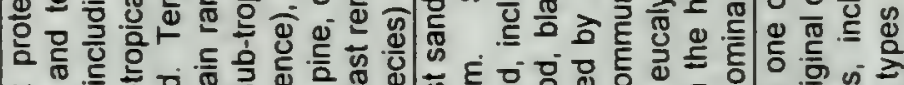

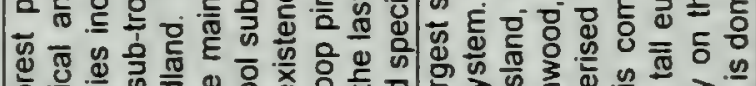

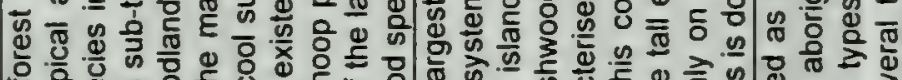

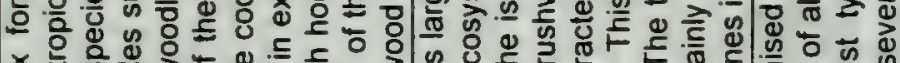

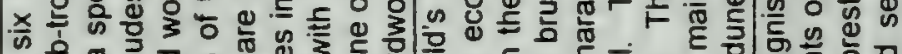

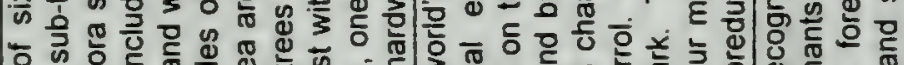

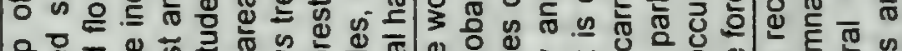
윽항

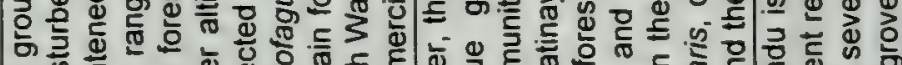
늫

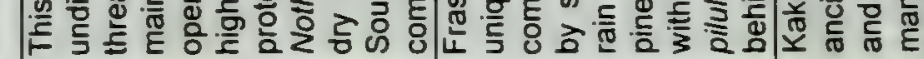

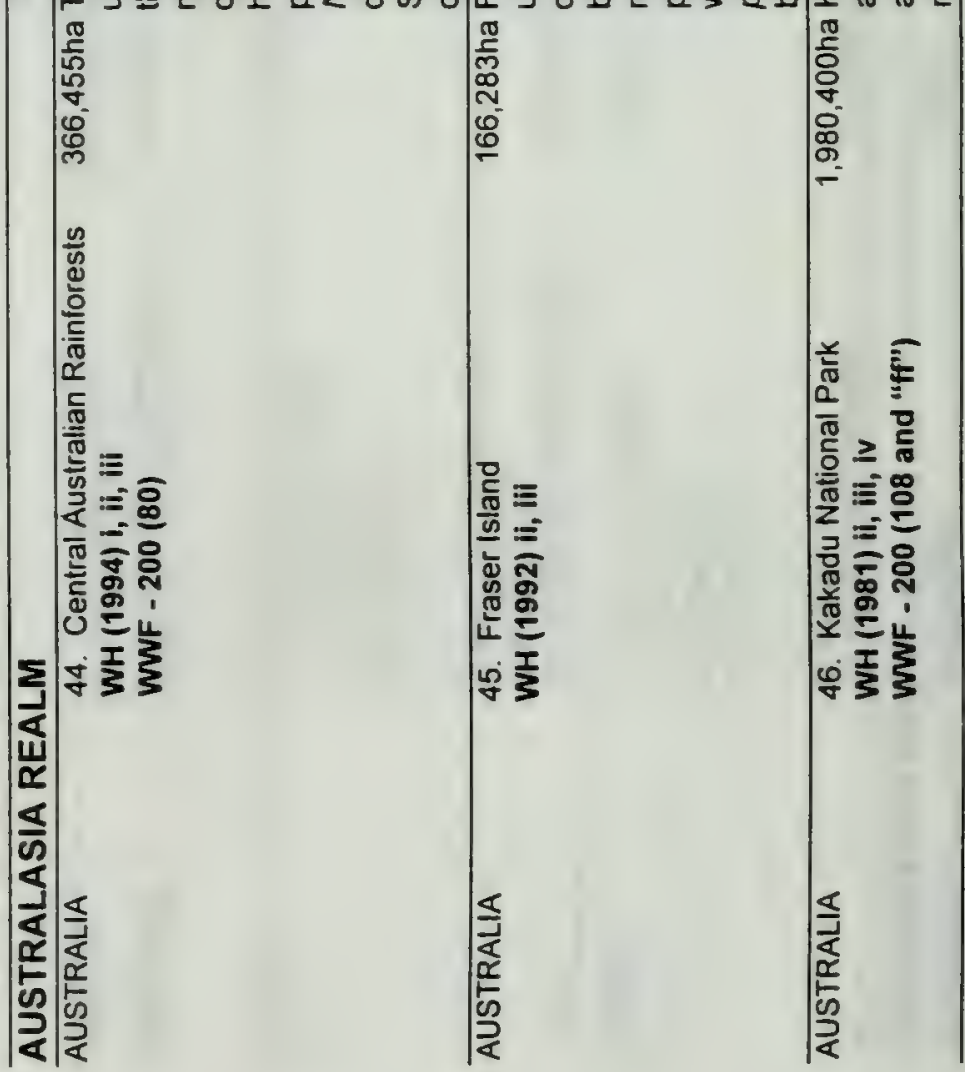


은 苟市

劳

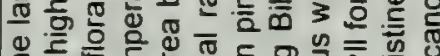

导

2 읃

은

눈 $\frac{\pi}{3}$

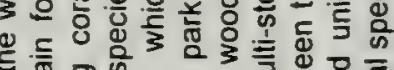
ᄃ 

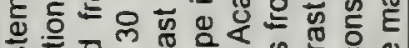

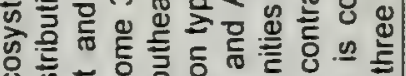
\&

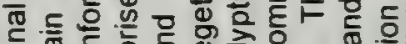
फ 西 要

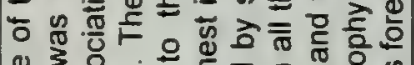

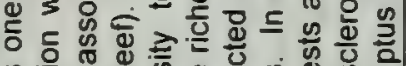

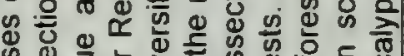

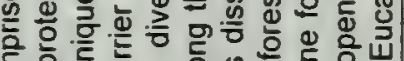

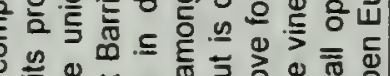

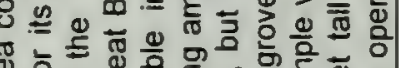

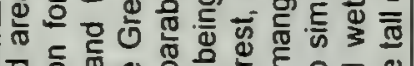

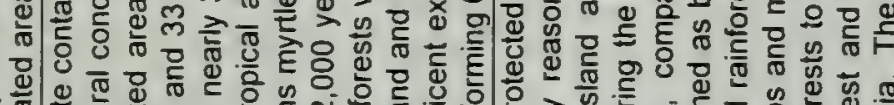

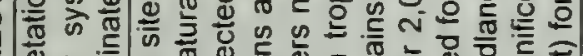

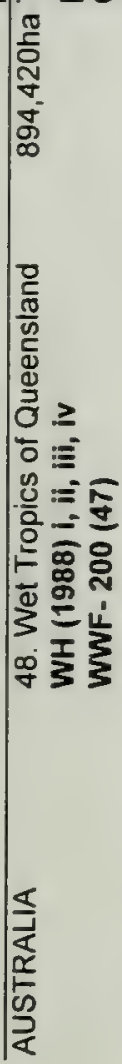
क्रि

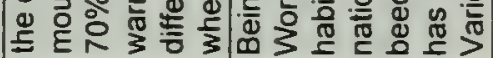
告

总<smiles>C[C@H]1[C@H]2C[C@@H]1C2</smiles>

का

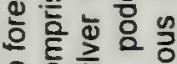
웅 등흐음

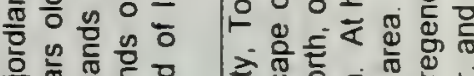

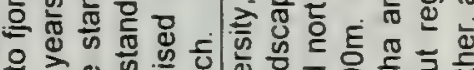

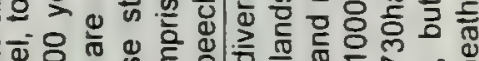

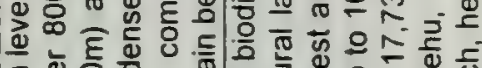
ळ E

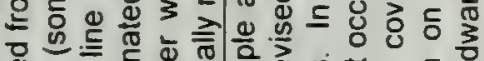

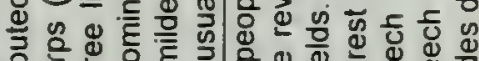
总突

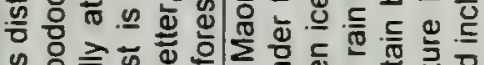
응 둔

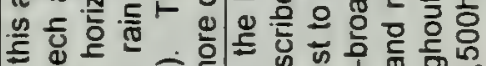

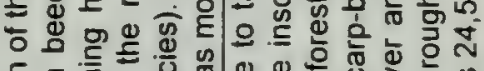
든

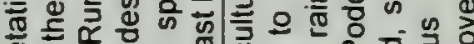
ब i

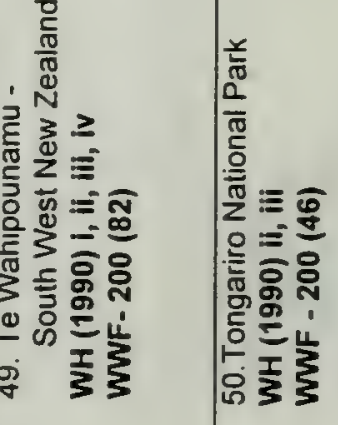

(2) 


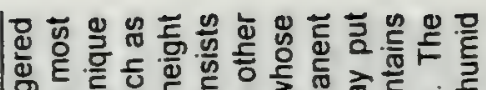

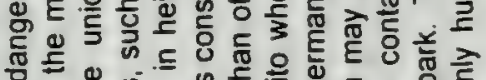

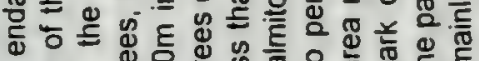

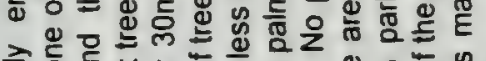

층 든 눙 러

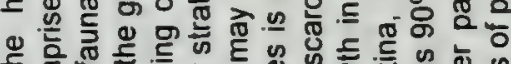

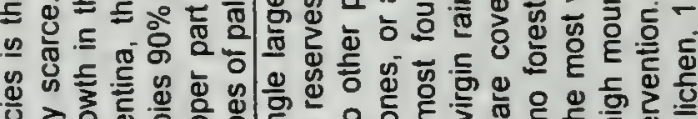
万人 0 on

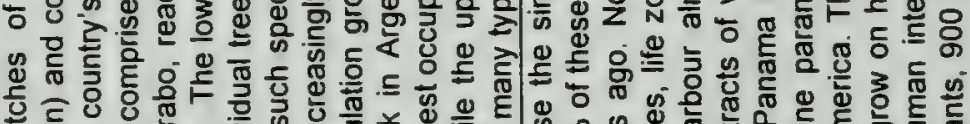

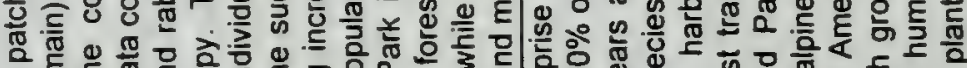

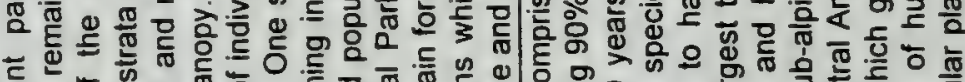

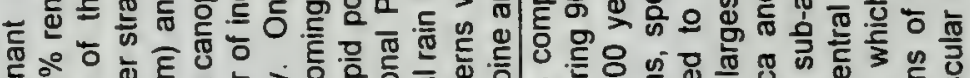

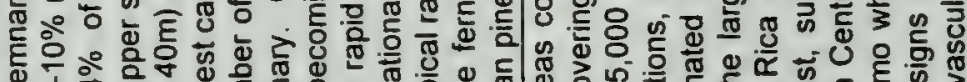
凹 凹

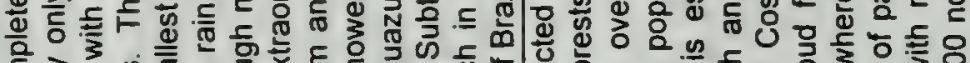

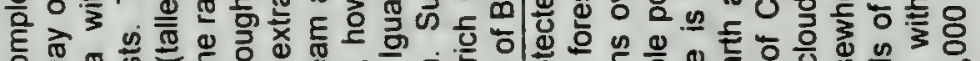

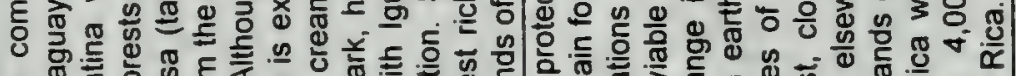
फ

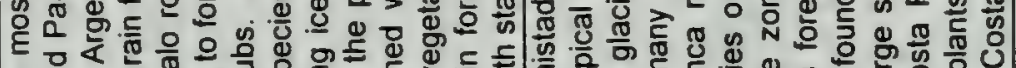
凹

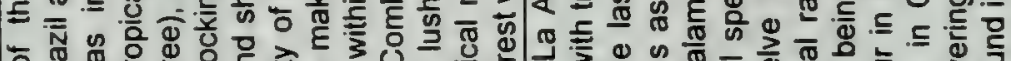
ర

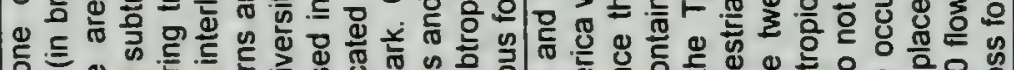

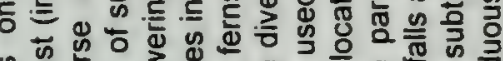
芯出 잉

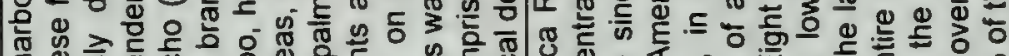

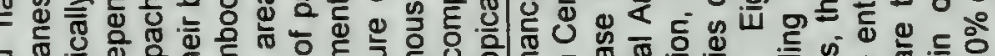
उ

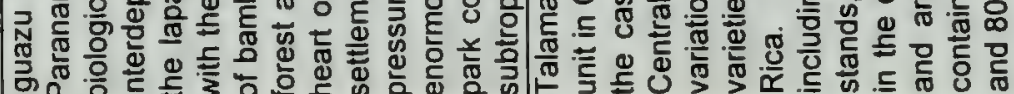
중 동 8

กิ

उ ํㅡㄹ 으는 ㄴ. ب

这

z os

$\sin$

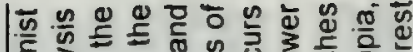

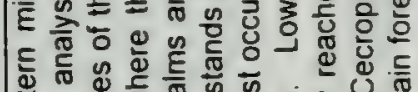
光 ज。 论 

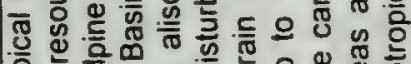

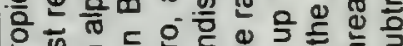

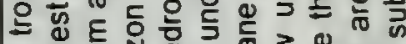

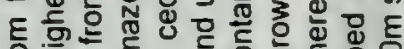

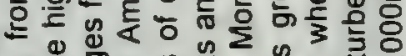

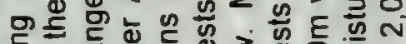

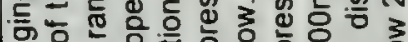
당 ॠ ๘뜡

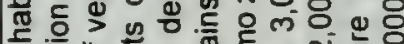

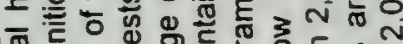

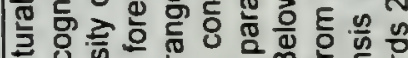
范

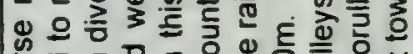

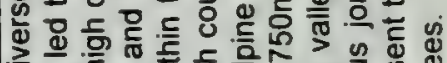

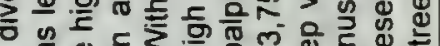

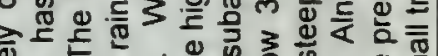
ब

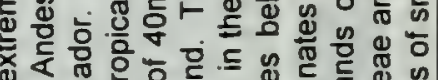

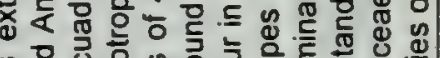

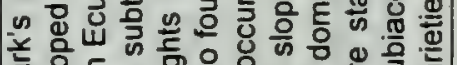

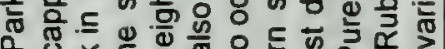

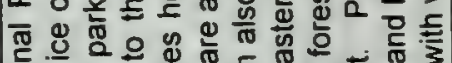

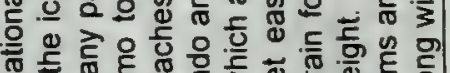

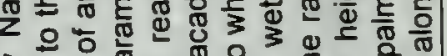

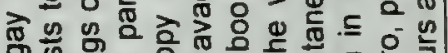

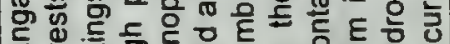

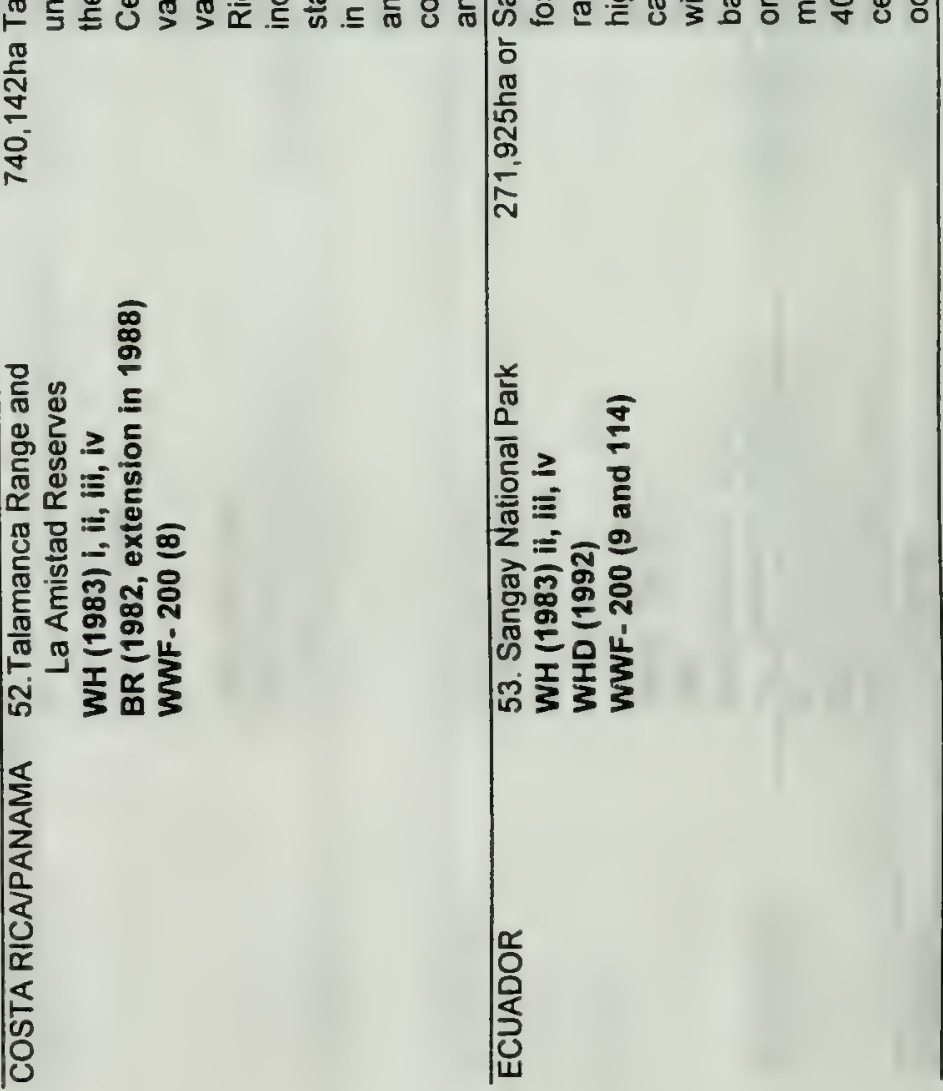




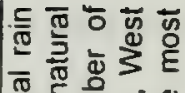

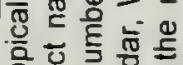

要

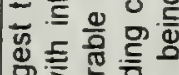

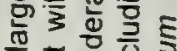

Ð

$\equiv$ 응 के

뜨 $\frac{0}{0}$.

들 응응

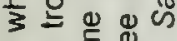

证

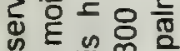

政

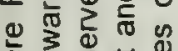

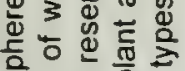

落 $>0$

\%然

5 .

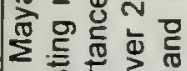

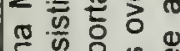

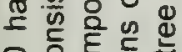

O० o

(0.

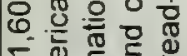

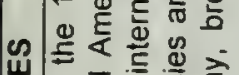

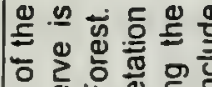

\& 4 ษ 등.

万ิ

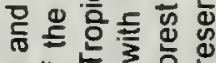

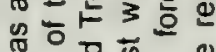

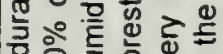

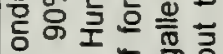

두유 응

던 은 응 익

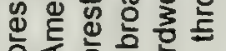

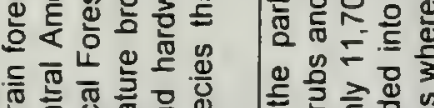

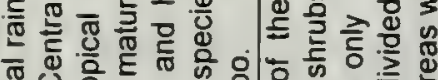

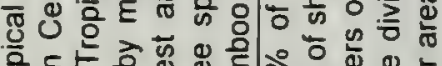

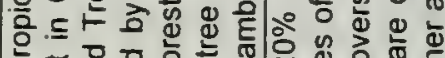

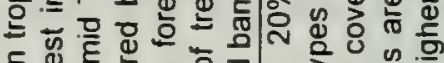

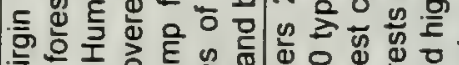

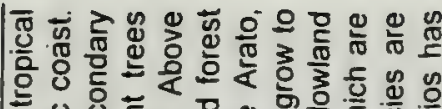

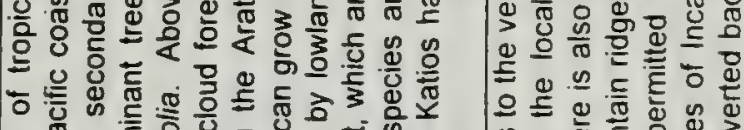
品 政

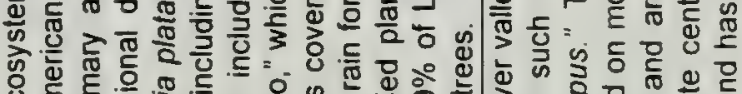
8.

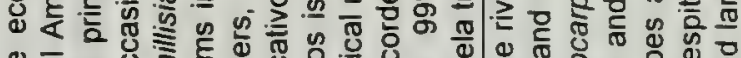

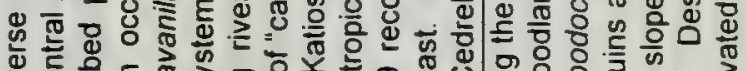

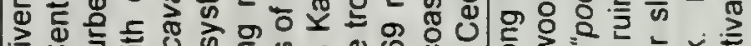

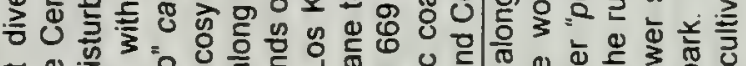

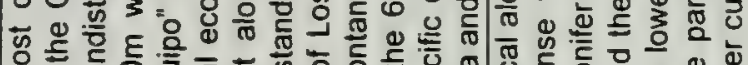
E.

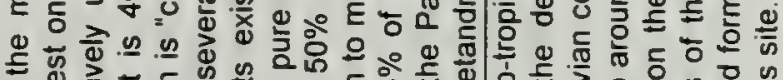

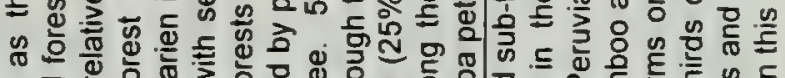

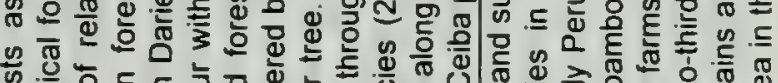

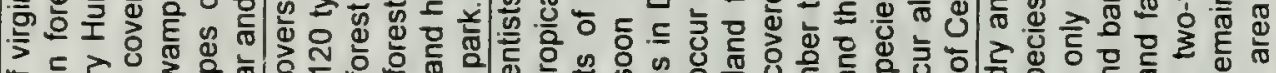

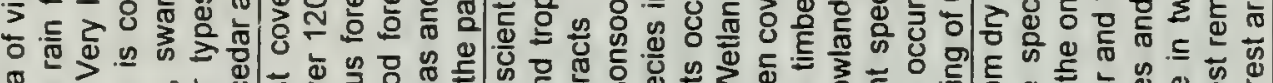

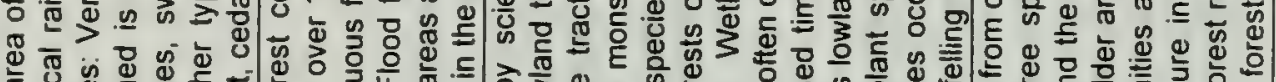
万人.

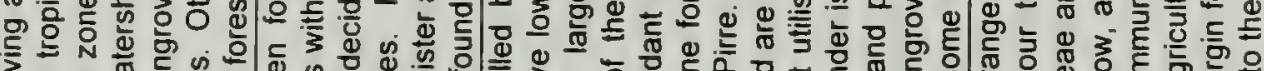

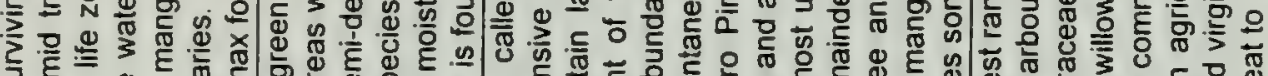

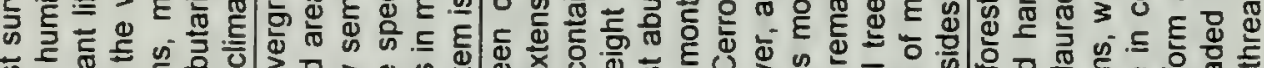

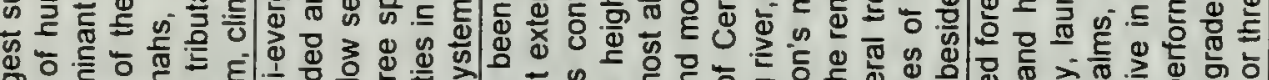

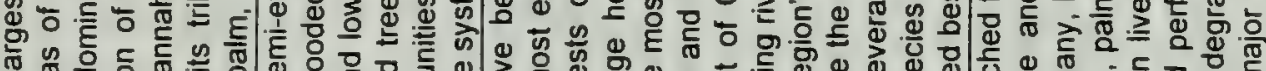

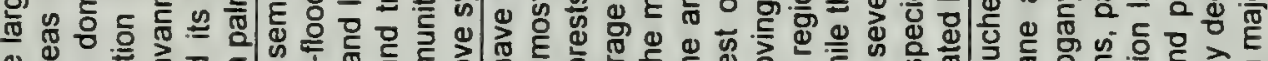

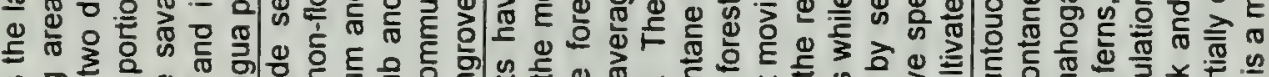

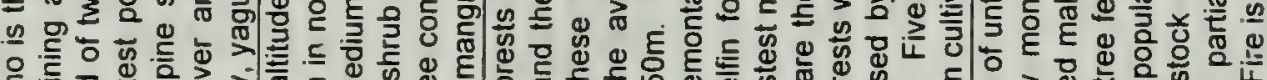

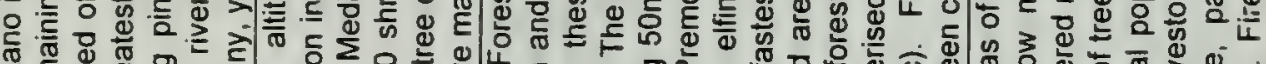

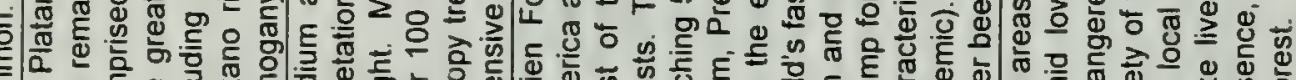

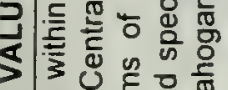
政.

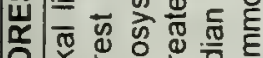

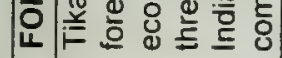

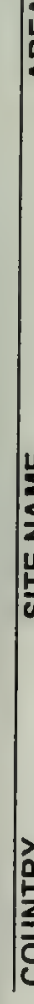

辰

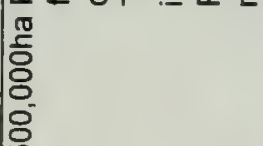

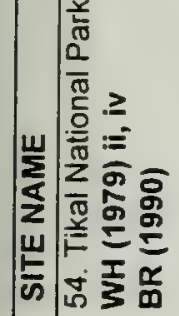

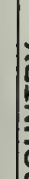

in

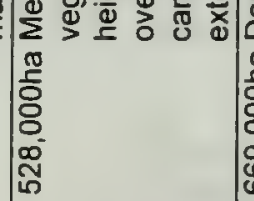

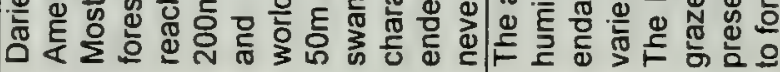

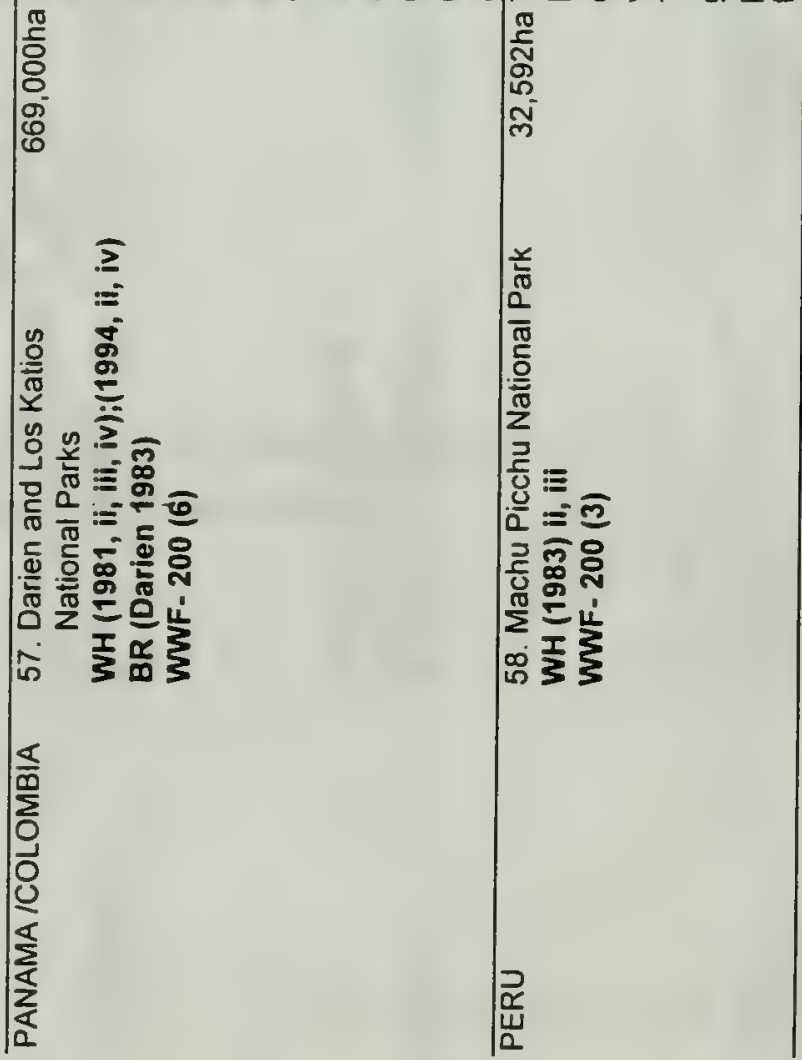




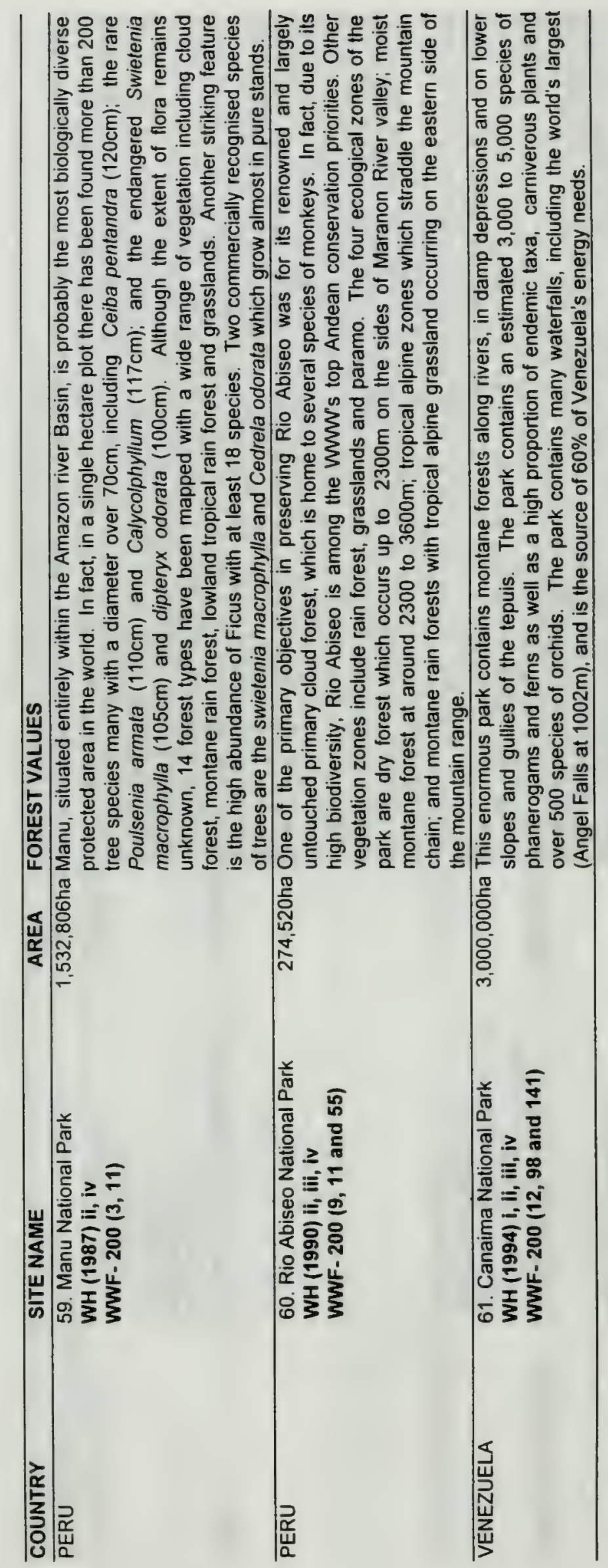




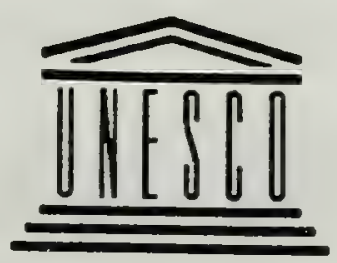

UNITED NATIONS EDUCATIONAL, SCIENTIFIC AND CULTURAL ORGANISATION

INTERGOVERNMENTAL COMMITTEE FOR THE PROTECTION OF THE WORLD CULTURAL AND NATURAL HERITAGE

Operational Guidelines for the Implementation of the World Heritage Convention 
43. In accordance with Article 2 of the Convention, the following is considered as "natural heritage":

"natural features consisting of physical and biological formations or groups of such formations, which are of outstanding universal value from the aesthetic or scientific point of view;

geological and physiographical formations and precisely delineated areas which constitute the habitat of threatened species of animals and plants of outstanding universal value from the point of view of science or conservation;

natural sites or precisely delineated natural areas of outstanding universal value from the point of view of science, conservation or natural beauty."

44. A natural heritage property - as defined above - which is submitted for inclusion in the World Heritage List will be considered to be of outstanding universal value for the purposes of the Convention when the Committee finds that it meets one or more of the following criteria and fulfills the conditions of integrity set out below. Sites nominated should therefore:

(a) (i) be outstanding examples representing major stages of earth's history, including the record of life, significant on-going geological processes in the development of land forms, or significant geomorphic or physiographic features; or

(ii) be outstanding examples representing significant on-going ecological and biological processes in the evolution and development of terrestrial, fresh water, coastal and marine ecosystems and communities of plants and animals; or

(iii) contain superlative natural phenomena or areas of exceptional natural beauty and aesthetic importance; or

(iv) contain the most important and significant natural habitats for in-situ conservation of biological diversity, including those containing threatened species of outstanding universal value from the point of view of science or conservation;

and

(b) also fulfil the following conditions of integrity:

The sites described in 44 (a)(i) should contain all or most of the key interrelated and interdependent elements in their natural relationships; for example, an "ice age" arez should include the snow field. the glacier itself and samples of cutting patterns, deposition and colonization 
(e.g. striations, moraines, pioneer stages of plant succession. etc.); in the case of volcanoes, the magmatic series should be complete and all or most of the varieties of effusive rocks and types of eruptions be represented.

The sites described in 44 (a)(ii) should have sufficient size and contain the necessary elements to demonstrate the key aspects of processes that are essential for the long-term conservation of the ecosystems and the biological diversity they contain; for example, an area of tropical rain forest should include a certain amount of variation in elevation above sea-level, changes in topography and soil types, patch systems and naturally regenerating patches; similarly a coral reef should include, for example, seagrass, mangrove or other adjacent ecosystems that regulate nutrient and sediment inputs into the reef.

The sites described in 44(a)(iii) should be of outstanding aesthetic value and include areas that are essential for maintaining the beauty of the site; for example, a site whose scenic values depend on a waterfall, should include adjacent catchment and downstream areas that are integrally linked to the maintenance of the aesthetic qualities of the site.

(iv) The sites described in paragraph 44(a)(iv) should contain habitats for maintaining the most diverse fauna and flora characteristic of the biographic province and ecosystems under consideration; for example, a tropical savannah should include a complete assemblage of co-evolved herbivores and plants; an island ecosystem should include habitats for maintaining endemic biota; a site containing wide-ranging species should be large enough to include the most critical habitats essential to ensure the survival of viable populations of those species; for an area containing migratory species, seasonal breeding and nesting sites, and migratory routes, wherever they are located, should be adequately protected; intemational conventions, e.g. the Convention of Wetlands of International Importance Especially as Waterfowl Habitat (Ramsar Convention), for ensuring the protection of habitats of migratory species of waterfowl, and other multi- and bilateral agreements could provide this assurance.

(v) The sites described in paragraph 44 (a) should have a management plan. When a site does not have a management plan at the time when it is nominated for the consideration of the World Heritage Committee. the State Party concerned should indicate when such a plan will become available and how it proposes to mobilize the resources required for the preparation and implementation of the plan. The State Party should also provide other document(s) (e.g. operational plans) which will guide the management of the site until such time when a management plan is finalized. 
A site described in paragraph th(a) should have adequate long-:em... legislative. regulatory or institutiona! protection. The boundaries of that site should reflect the spatial requirements of habitats. species. processes or phenomena that provide the basis for its nomination for inscription on the World Heriage List. The bounciares should include sufficient areas immediately adjacent to the area of outsianding universal value in order to protect the site's heritage values from direc: effects of human encroachment and impacts of resource use outside of the nominated area. The boundaries of the nominated site may coincide with one or more existing or proposed protected areas, such as national parks or biosphere reserves. While an existing or proposed protected area may contain several management zones, only some of those zones may satisfy criteria described in paragraph 4:(a); other zones, although they may not meet the criteria set out in paragraph $\$ 千$ (a), may be essential for the management to ensure the integrity of the nominated site; for example, in the case of a biosphere reserve, only the core zone may meet the criteria and the conditions of integrity, although other zones, i.e. buffer and transitional zones, would be important for the conservation of the biosphere reserve in its totality.

(vii) Sites described in paragraph 44 (a) should be the most important sites for the conservation of biological diversity. Biological diversity, according to the new global Convention on Biological Diversity, means the variability among living organisms in terrestrial. marine and other aquatic ecosystems and the ecological complexes of which they are part and includes diversity within species, berween species and of ecosystems. Only those sites which are the most biologically diverse are likely to meet criterion (iv) of paragraph 44 (a).

45. In principle, a site could be inscribed on the World Heritage List as long as it satisfies one of the four criteria and the relevant conditions of integrity. However, most inscribed sites have met two or more criteria. Nomination dossiers, IUCN evaluations and the final recommendations of the Committee on each inscribed site are available for consultation by States Parties which may wish to use such information as guides for identifying and elaborating nomination of sites within their own territories.

\section{E. Procedure for the eventual deletion of properties from the World Heritage List}

46. The Commitee adopted the following procedure for the delation of properties from the World Heritage List in cases:

(a) where the propery has deteriorated to the extent that it has lost those characteristics which detemined its inclusion in the World Heritage List. and 



\section{World Headquarters}

IUCN - The World Conservation Union

Rue Mauverney 28

$\mathrm{CH}-1196$ Gland, Switzerland

Tel. : $\quad++41229990001$

Fax: $\quad++41229990002$

http://www.iucn.org 